\title{
Stratigraphy of the
}

Wind River Formation in

\section{South-Central Wind River}

\section{Basin, Wyoming}

GEOLOGIGAL SURVEY PROFESIONAL PAPER 594-A

Prepared in cooperation with the

U.S. Atomic Energy Commission

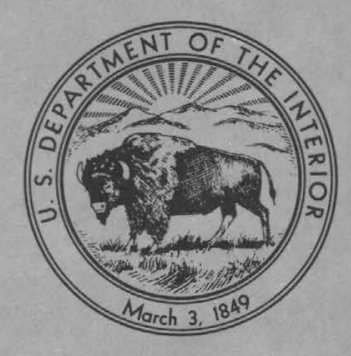




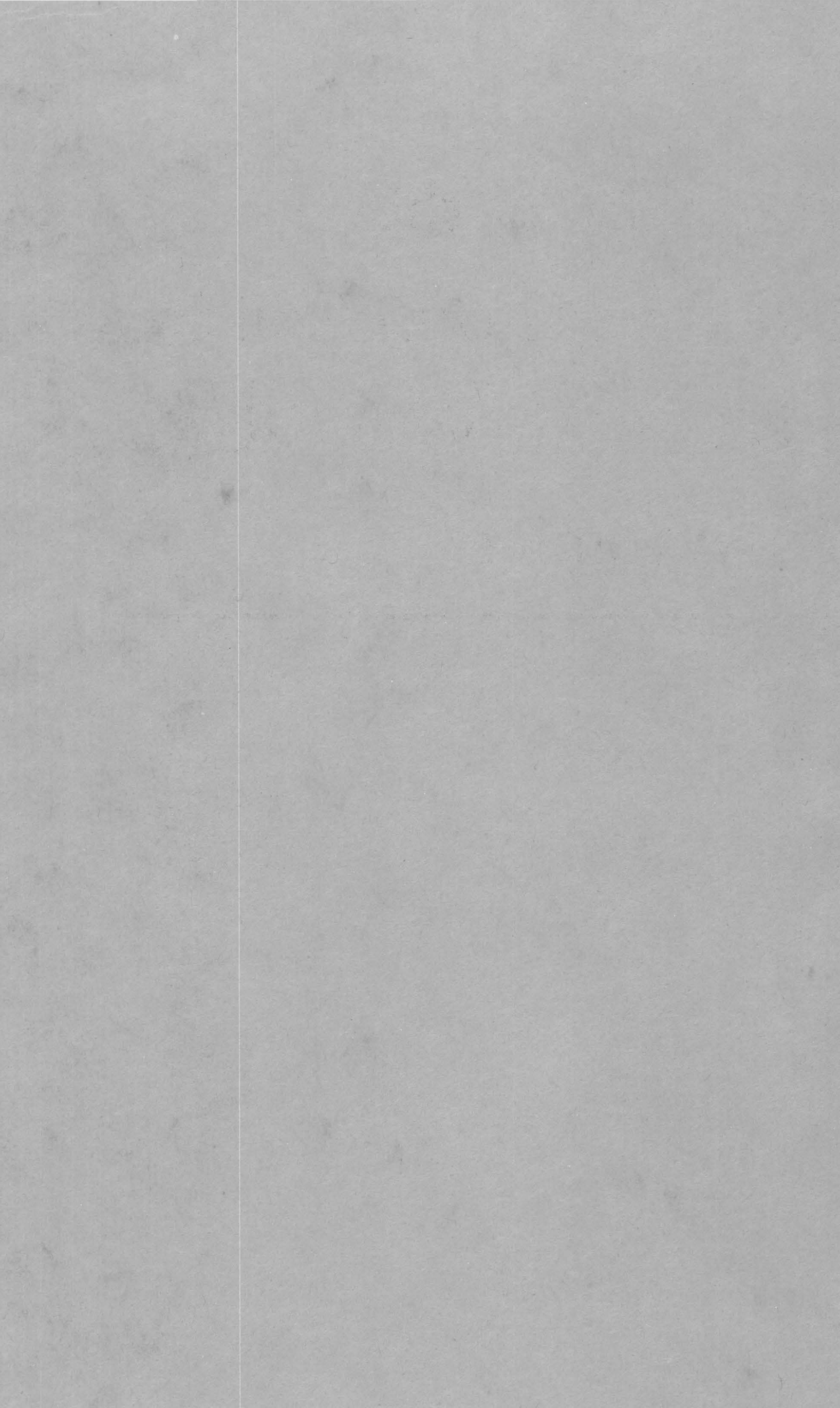


STRATIGRAPHY OF THE WIND RIVER FORMATION IN SOUTH-CENTRAL WIND RIVER BASIN 


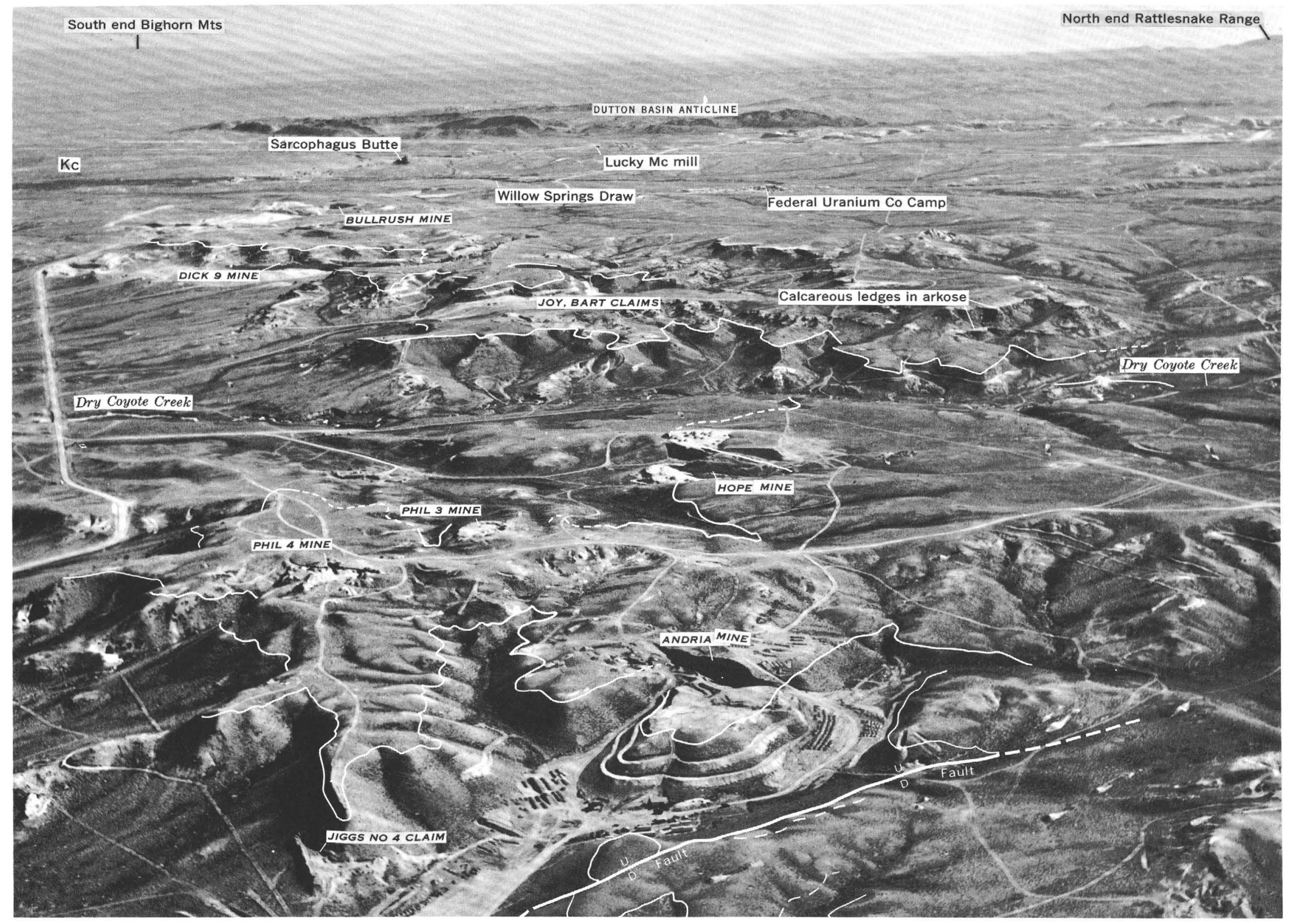

Part of south-central Wind River Basin. View northeastward from a point about one-half mile north of Coyote Springs. Puddle Springs Arkose Member of the Wind River Formation underlies most of area of photograph. Lines trace outcrop of Dry Coyote Conglomerate Bed (top and base not shown) of the Puddle Springs Arkose Member. Kc, Cody Shale. Aerial photograph courtesy of Page Jenkins. 


\section{Stratigraphy of the}

Wind River Formation in

\section{South-Central Wind River}

\section{Basin, Wyoming}

By PAUL E. SOISTER

SHORTER CONTRIBUTIONS TO GENERAL GEOLOGY

GEOLOGICAL SURVEY PROFESSIONAL PAPER 594-A

Prepared in cooperation with the

U.S. Atomic Energy Commission

$A$ detailed study of the physical stratigraphy of the uranium-bearing formation in and near the important Gas Hills uranium district of central

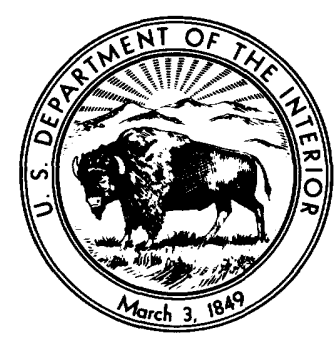

Wyoming 
UNITED STATES DEPARTMENT OF THE INTERIOR

STEWART L. UDALL, Secretary

GEOLOGICAL SURVEY

William T. Pecora, Director

For sale by the Superintendent of Documents, U.S. Government Printing Office, Washington, D.C. 20402 


\section{CONTENTS}

Abstract.-.

Introduction.

Geologic setting

Wind River Formation

History of stratigraphic terms

Paleontology and stratigraphic position

General lithology and thickness.

Occurrence and facies relations.

Correlations

Lithologic units

Lower fine-grained member

Conglomerate.

Sandstone.

Siltstone...

Claystone...

Carbonaceous beds_._.

Puddle Springs Arkose Member.

General description and occurrence.

Rock types and units.

Channel sandstone beds.

Landslide debris from the Mowry Shale.

Carbonaceous beds and carbonized and silicified wood

East Canyon Conglomerate Bed

Dry Coyote Conglomerate Bed

Muskrat Conglomerate Bed.

Other conglomerate beds.

Upper transition zone.

Page

A1

Source of sediments

Depositional environment.

Paleogeography

Paleoclimate._.

Deposition of sediments.

Stratigraphic position of uranium deposits

References cited.

\section{ILLUSTRATIONS}

[Plates 1-5 are in pocket]

Plate 1. Geologic map of south-central Wind River Basin.

2-4. Stratigraphic sections of Wind River Formation:

2. Areas $A$ and $B$.

3. Areas $C$ and $D$.

4. Areas $\mathrm{E}, \mathrm{F}$, and $\mathrm{G}$.

5. Geologic map showing outcrop of Dry Coyote and Muskrat Conglomerate Beds.

Frontispiece. Part of south-central Wind River Basin. View northeastward from a point about one-half mile north of Coyote Springs.

Frgure 1. Index map of central Wyoming.

2. Map of the south-central part of the Wind River Basin showing location of measured sections, facies and other boundaries, and depositional edge of the Wind River Formation. 
Figdre 3. Photograph showing exhumed ridges and valleys of breached Dutton Basin anticline and large open-pit uranium mines in the Puddle Springs Arkose Member.

4. Photograph of Beaver Divide escarpment southeast of Coyote Springs

5. Diagrammatic section of Wind River Formation in south-central and central Wind River Basin

6. Isopach map showing original thickness of Wind River Formation and physiographic features of pre-Tertiary rocks that affected deposition of the sediments.

7. Diagrammatic stratigraphic section of Wind River Formation near south-central edge of Wind River Basin

8. Photographs showing lower fine-grained member of the Wind River Formation

9. Map of an area south of Coyote Springs showing variation in thickness of a carbonaceous shale penetrated by drill holes.

10. Photographs of the coal and carbonaceous shale of the central carbonaceous zone at a Lucky Mc open-pit uranium mine

11. Map showing present extent of central carbonaceous zone of lower fine-grained member of Wind River Formation and approximate position and geology of highlands during its deposition

12. Diagrammatic section of flat, tabular body containing limonite, manganese, and uranium in sandstone above Dry Coyote Conglomerate Bed

13. Geologic map and cross sections showing lower Eocene landslide debris from the Mowry Shale west of Coyote Springs_...

14. Photographs of lower Eocene landslide debris from the Mowry Shale

15. Paleogeographic map showing approximate limits of East Canyon Conglomerate Bed and position of highlands during deposition of the sediments.

16-19. Photographs showing:

16. Dry Coyote Conglomerate Bed exposed in a uranium prospect pit

17. Dry Coyote Conglomerate Bed in W1/2 sec. 32, T. 33 N., R. 90 W.

18. Conglomerate and sandstone of the Puddle Springs Arkose Member exposed in an open-pit uranium mine

19. Marker beds in lower part of Wagon Bed Formation and part of upper transition zone of the Wind River Formation

\section{TABLE}

TABLE 1. Rocks overlapped by Wind River Formation in areas shown in figure 2 


\title{
STRATIGRAPHY OF THE WIND RIVER FORMATION IN SOUTH-GENTRAL WIND RIVER BASIN WYOMING
}

\author{
By Paul E. Soister
}

\begin{abstract}
The area of this report is the south-central part of the Wind River Basin in central Wyoming and includes the Gas Hills uranium district. All the known economic uranium deposits of the district occur in the Wind River Formation.

The sediments of the Wind River Formation were deposited on an erosion surface cut on rocks of Late Cretaceous to Cambrian age on the north flank of the ancestral Granite Mountains (core of the Sweetwater uplift). The original thickness of the formation here ranged from 0 feet at the south to at least 1,000 feet at the north, but the thickest known preserved section, in a drill hole, is 835 feet. No diagnostic fossils have been found, but most of the formation is probably of late early Eocene (Lost Cabin) age. The formation grades upward into the Wagon Bed Formation of middle and late Eocene age. Although the dip of the strata initially was to the north, it is now about $1^{\circ}-3^{\circ} \mathrm{S}$., as a result of post-Miocene normal faulting and collapse of the Sweetwater uplift.

Whereas over most of the Wind River Basin the Wind River Formation consists mainly of variegated to drab claystone and siltstone with interbedded lenticular to sheetlike sandstone beds, in the report area it consists mainly of a coarse massive arkose. Here, the formation is subdivided into a lower fine-grained member (0-130 feet thick), the Puddle Springs Arkose Member (about 400-800 feet thick), and an upper transition zone (generally 50-100 feet thick).

The lower fine-grained member consists of, in decreasing order, grayish-green siltstone, light-gray very fine-grained to fine-grained sandstone, olive- to grayish-green and some red claystone, brown to black carbonaceous shale and coal, and a thin basal or nearly basal chert-pebble conglomerate. Near the west flank of the Dutton Basin anticline these sediments are predominantly from Mesozoic rocks, but in other places the siltstone and sandstone contain large amounts of chlorite and biotite flakes and other Precambrian materials. Immediately southwest and south of the Dutton Basin anticline, a persistent carbonaceous shale and coal zone, generally about 5-15 feet thick, lies at or just below the top of the lower fine-grained member in drill holes in an area of about 7 square miles. This interval is informally known as the central carbonaceous zone.

The Puddle Springs Arkose Member consists primarily of massive very coarse to coarse-grained conglomeratic arkosic sandstone and granite granule to boulder conglomerate with thin beds of finer grained feldspathic to arkosic sandstone, siltstone, claystone, and rare thin beds of carbonaceous shale; carbonized
\end{abstract}

and silicified wood are common in parts of the arkose. Cementing or interstitial materials include clay, gypsum, limonite, calcite, jarosite, pyrite, black manganese oxides, carbonate fluorapatite, silica, and hydrozircon, as well as minerals of selenium, arsenic, molybdenum, and uranium. The arkose is oxidized and mostly grayish yellow at and near the surface, but below the zone of oxidation, particularly below the water table, it is generally blue, green, or gray. In the area of this report the coarse arkose interfingers to the east and west with finer grained rocks similar to those in the lower fine-grained member. All or most of the Puddle Springs has been removed by erosion in the northern part of and just north of the area.

Three granite boulder conglomerate beds in the Puddle Springs Arkose Member have been mapped and traced in drill holes. The Dry Coyote and Muskrat Conglomerate Beds are sheetlike and about 10-30 feet thick where they crop out; the Dry Coyote is roughly 100 feet stratigraphically below the Muskrat. The East Canyon Conglomerate Bed, generally 200-300 feet thick, is a major channel deposit about $2-3$ miles wide and more than 15 miles long. Exhumed landslide debris of Mowry Shale (Lower Cretaceous) fragments and segments of beds occur west of Coyote Springs in approximately the same stratigraphic interval as the Dry Coyote Conglomerate Bed.

The upper part of the formation is informally known as the upper transition zone because numerous beds of tuffaceous and bentonitic mudstone are interbedded with the arkose. These mudstone beds are similar to those in the overlying Wagon Bed Formation. Drab color of this zone contrasts with the green and thin bright-red beds of the typical fine-grained parts of the formation.

The erosion surface on which the formation was deposited sloped generally northward toward the axis of the basin. Valleys and ridges with a few hundred feet of local relief cut on the preTertiary rocks were filled or overlapped by the Wind River Formation. During deposition of the Puddle Springs Arkose Member the ancestral Granite Mountains stood perhaps 5,0006,500 feet higher than the north edge of this area. Mainly as a result of post-Miocene subsidence of the Sweetwater uplift, the relief at present is only about 2,000 feet. Climate of the basin during Wind River time was probably warm-temperate and slightly to moderately humid.

Abrupt thinning onto ridges and local highlands of preTertiary rocks is a characteristic of the formation in this area. Lateral variation from west to east in the formation allows designation of seven subareas. In the western and eastern subareas, the formation consists almost entirely of interbedded 
fine-grained variegated and minor coarse-grained arkosic beds and is not clearly divisible into members. Between these two subareas, it is generally divisible into the lower fine-grained member, the Puddle Springs Arkose Member, and the upper transition zone. The west-to-east variation in the formation, normal to the direction of sediment transport, is due to the paleogeography.

All known economic uranium deposits of the Gas Hills uranium district, totaling at least 10 million tons of ore, are in the Puddle Springs Arkose Member only where this member is well developed. There are no known deposits in the lower fine-grained member except at the top in the central area, and none are in the upper transition zone. There are no known deposits in the western and eastern parts of the area where much of the formation consists of fine-grained rocks nor in the broad area underlain by the formation directly north of the district. The coarse-grained porous and highly permeable nature of the Puddle Springs Arkose Member is probably the most important single factor, after source of the uranium, contributing to occurrence of the very large uranium deposits in this district. The coarse arkose may be the source of, as well as the host rock for, the uranium. Therefore, southward tilting and downfaulting into subsidiary basins has allowed the uranium to accumulate more rapidly than the coarse arkosic sediments could be removed by Quaternary erosion.

\section{INTRODUCTION}

The south-central part of the Wind River Basin is in central Wyoming and includes the Gas Hills uranium district (frontispiece; fig. 1). The stratigraphic information on the district for this report is based mainly on work done by the U.S. Geological Survey on behalf of the Division of Raw Materials of the U.S. Atomic Energy Commission in 1954-58. Earliest work by the U.S. Geological Survey on the Gas Hills uranium deposits was done in late 1953 by Love (1954). From July 1954 through the summer of $1956 \mathrm{H}$. D. Zeller and the author, assisted by H. J. Hyden, M. J. Bergin, J. P. McDowell, R. L. Koogle, and R. A. MacDiarmid, mapped and studied the uranium deposits (Zeller, 1957; Zeller and others, 1956; Soister, 1958).

Mineralogical and geochemical studies of some uranium ore deposits and of some of the arkosic sediments of the Wind River Formation were made by R. G. Coleman. Seismic surveys, which confirmed faults and thus aided in interpretation of stratigraphy, were made by R. M. Hazlewood and John Roller.

Eight core holes drilled in 1955 by the Atomic Energy Commission and logged by Bruce Kibbler, Atomic Energy Commission, were of great value to this work. Data from some holes drilled and logged by private companies on uranium claims were made available. These companies include the Globe Mining Co., Utah Construction and Mining Co. and Lucky Mc Uranium Corp., Vitro Uranium Corp., Cyprus Mining Co.,
Amerada Petroleum Co., American Smelting and Refining Co., Western Nuclear Corp., Aljob Mining Co., P-C Mining Co., Dale B. Levi, Lisbon Uranium Corp., and Four Corners Uranium Corp. A few holes were logged by the writer and by R. A. MacDiarmid, and several holes were logged by H. D. Zeller.

J. L. Weitz of the U.S. Geological Survey and J. P. Hadfield, Jr., of the Atomic Energy Commission, explained the general stratigraphy of the area to the field party at the beginning of the work. During 195455 stratigraphic sections were measured by the author, H. D. Zeller, H. J. Hyden, J. P. McDowell, R. L. Koogle, and R. A. MacDiarmid. Most of the surface stratigraphic sections of this report were measured and all correlations made by the author in 1956-58. Discussions with N. M. Denson, D. C. Duncan, and J. D. Love were useful in this study.

The stratigraphic study involved geologic mapping and measuring of sections in the nearly horizontal beds of the Wind River Formation by the hand-level and tape method and, also, compiling and interpreting drill hole logs. Some of the available data from drill holes are not precise, and grain size, color, and composition of the rocks are only approximated in some logs. For example, the "shale" of one well logger may be the clay, silt, or mudstone of others, or may even be very fine grained sandstone; some of the rocks reported as "coarse-grained sandstone" prove on close examination to be as coarse as granule conglomerate. In the stratigraphic study, the author has attempted to interpret the textural data and has standardized the lithologic descriptions.

In this report, the Wentworth (1922) scale is used in describing grain size of clastic rocks, and the National Research Council "Rock-Color Chart" (Goddard and others, 1948) is used to describe colors.

\section{GEOLOGIC SETTING}

The Wind River Formation overlaps progressively older formations southward along the south-central edge of the Wind River Basin and the north flank of the Sweetwater uplift. The subjacent rocks range in age from Paleocene to Cambrian and possibly Precambrian. They were folded during Cretaceous and early Tertiary time and deeply eroded prior to deposition of sediments of the Wind River Formation in early Eocene time. The older rocks dip generally $5^{\circ}-15^{\circ} \mathrm{N}$., except on the breached northwest-plunging Laramide folds, where beds are steep and locally overturned. In contrast, the Wind River Formation dips about $1^{\circ}-3^{\circ}$ S., except in the northern part of the area, where beds are mostly horizontal or dip very gently north. 


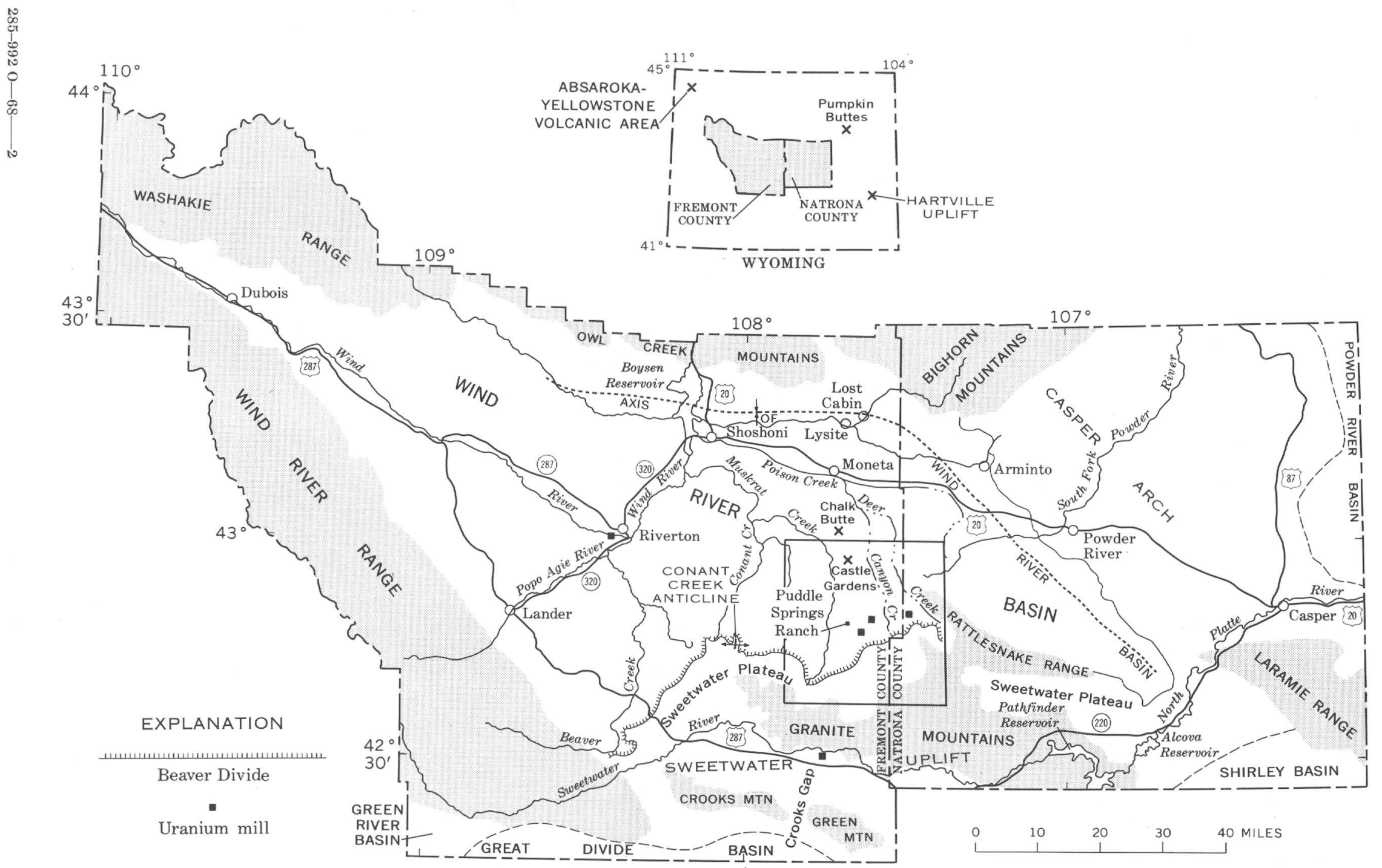

Figure 1.-Map of central Wyoming showing area of detailed stratigraphic investigations (within heavy line). Edge of Wind River Basin is defined mostly by the extent of rocks of early Eocene age. 
EXPLANATION

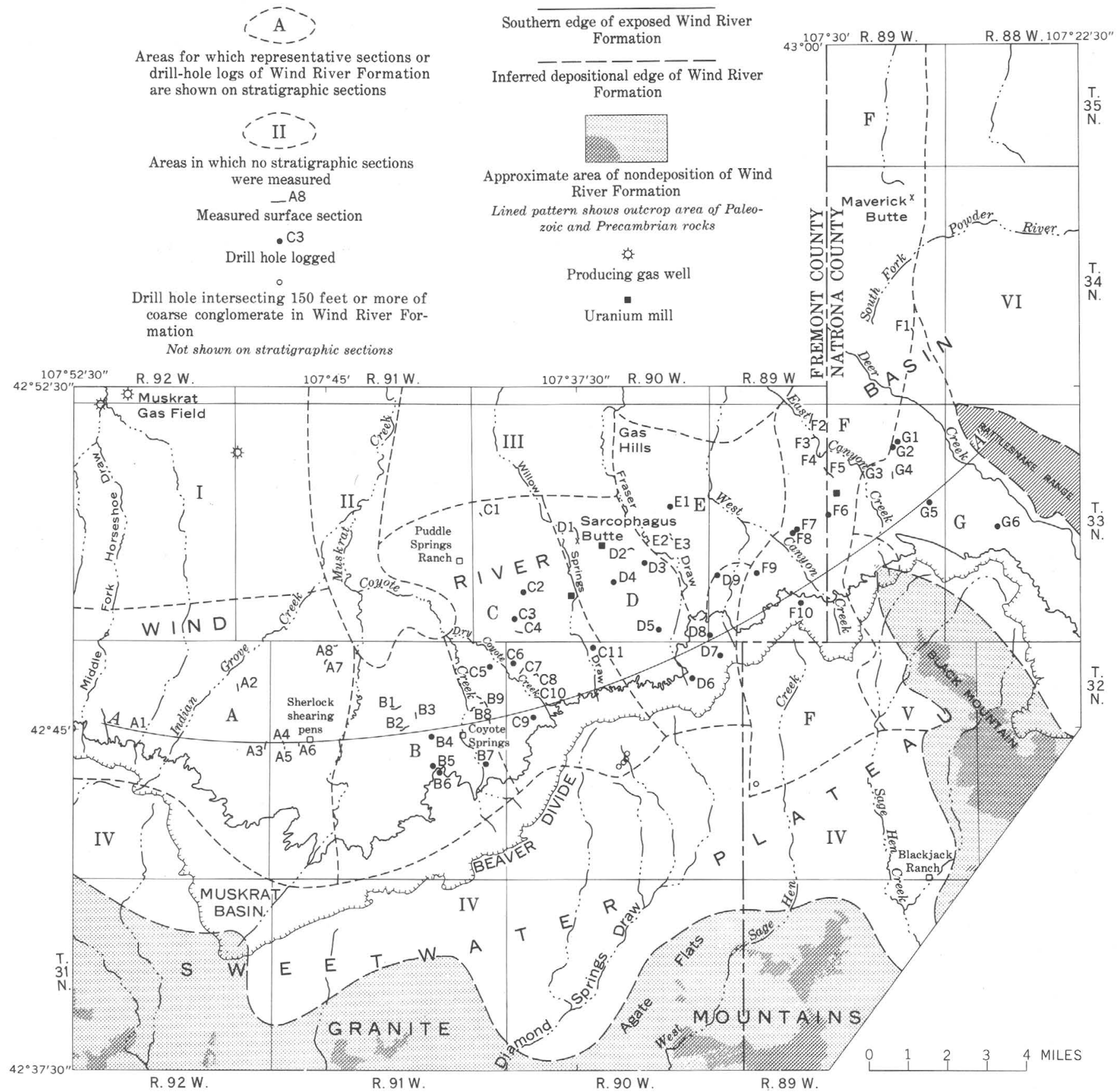

Figure 2.-Map of the south-central part of the Wind River Basin showing location of measured sections, facies and other boundaries, and depositional edge of the Wind River Formation. Numbered and lettered areas are discussed on facing page. Solid curved line $A-A^{\prime}$ represents section in figure 7 . 
General characteristics of Wind River Formation in areas shown in figure 2

[Thickness of formation refers to present thickness in one locality rather than original or composite thickness]

A. Fine-grained beds interfinger with thinner beds of coarse arkose. Formation contains lenses possibly equivalent to Dry Coyote Conglomerate Bed. Muskrat Conglomerate Bed traceable across area. Upper transition zone at least 100 feet thick. Maximum thickness of formation possibly 700 feet.

B. Typical lower fine-grained member about 100 feet thick in northern part but not measured. Numerous fine-grained beds in Puddle Springs Arkose Member. Dry Coyote and Muskrat Conglomerate Beds prominent. In subsurface, a thick carbonaceous shale extends over at least 1-2 square miles south of a buried ridge of the Mowry Shale. Upper transition zone not distinctive. Maximum thickness of formation possibly $550-600$ feet.

C. Typical lower fine-grained member about 120 feet thick in northern part. Typical Puddle Springs Arkose Member contains coarse arkosic conglomeratic sandstone and few fine-grained beds; Dry Coyote Conglomerate Bed prominent. Muskrat Conglomerate Bed absent owing to pinchout west of area. Upper transition zone not more than 50-120 feet thick. Maximum thickness of formation about 650 feet.

D. Typical lower fine-grained member about 120 feet thick present throughout area and central carbonaceous zone present at or just below top of this member over most of area. Overlying 100 feet consists of fine-grained beds with interbedded arkose. Puddle Springs Arkose Member is mainly coarse arkosic sandstone containing no cobble or boulder conglomerate. Dry Coyote Conglomerate Bed absent owing to pinchout near west border. Upper transition zone absent or thin. Maximum thickness of formation about 650 feet.

E. Area was generally too high for deposition of lower finegrained member. Puddle Springs Arkose Member lies on ridges and valleys of Mesozoic rocks on breached Dutton Basin anticline. Formation consists mainly of coarse arkosic sandstone; it contains at least one carbonaceous shale bed, some other fine-grained beds, and possibly a few conglomerate beds. Maximum thickness of formation possibly 250-300 feet.

F. Lower fine-grained member absent, possibly owing to erosion before deposition of thick coarse East Canyon Conglomerate Bed which lies at base of formation over most of this area. Formation mainly conglomerate and very coarse conglomeratic sandstone of Puddle Springs Arkose Member. Upper 200 feet or so of formation consists mainly of fine-grained, partly variegated beds somewhat similar to lower fine-grained member. Maximum thickness of formation possibly about 850 feet.

G. Typical lower fine-grained member may be present in deeper parts of area. Fine-grained variegated beds intertongue with coarse arkosic, slightly conglomeratic sandstone beds and a few thin pebble conglomerates typical of the Pud- dle Springs Arkose Member. East Canyon Conglomerate Bed wedge-edge in northern part of area. A few conglomerate beds in subsurface may fill channels from the southeast. Maximum thickness 'unknown, probably more than 650 feet.

I, II,

and

III. Wind River Formation, mostly removed by Quaternary erosion, is generally less than 100 feet thick; original thickness possibly about 1,000 feet. Formation lies on Cody Shale and Frontier Formation.

I. Mainly lower fine-grained member; some coarse to conglomeratic sandstone lenses and beds of Puddle Springs Arkose Member. Maximum thickness less than 150 feet.

II. Some variegated beds of lower fine-grained member. Mainly (1) basal or near-basal conglomerate of siliceous shale chips from the Mowry Shale and chert pebbles from the Cloverly Formation in matrix of quartzose sand, and (2) relatively thick calcareous arkosic channel sandstone of Puddle Springs Arkose Member. Less than 100 feet remaining.

III. Variegated beds and basal or near-basal conglomerate of lower fine-grained member. Less than 50 feet remaining.

IV. Formation covered by younger beds and characteristics not known; probably mainly coarse granitic debris of Puddle Springs Arkose Member ranging from coarse sand to huge boulders on alluvial fans. May contain finer grained rocks, especially in valleys between buried ridges of Paleozoic rocks. Thickness ranges from zero to several hundred feet.

V. Some drill-hole data indicate as much as a few hundred feet of coarse arkosic sandstone and conglomerate of Puddle Springs Arkose Member composing upper part of the Wind River Formation; the material was deposited on Paleozoic and possibly on Precambrian rocks.

VI. Area not studied.

TABLE 1.-Rocks overlapped by Wind River Formation in areas shown in figure 2

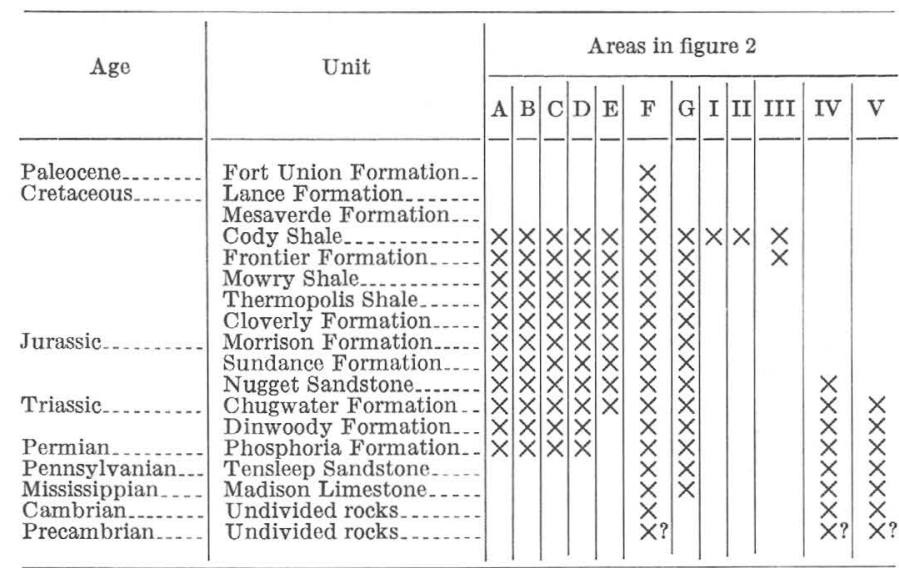


The erosion surface below the Wind River Formation locally has a relief of a few hundred feet, and the present total relief of this surface in the area is at least 1,400 feet. There is an additional 800 feet of relief on the pre-Wind River surface to the top of Black Mountain and the Rattlesnake Range, ${ }^{1}$ (pl. 1) but these higher parts of the map area were never covered by the Wind River Formation (fig. 2). Exhumed ridges and valleys formed on alternating hard and soft Mesozoic and Paleozoic strata are particularly conspicuous at the north end of the Rattlesnake Range and on the flanks of the Dutton Basin anticline (fig. 3).

The Wind River Formation is conformably overlain by the Wagon Bed Formation of middle and late Eocene age (Van Houten, 1964). Quartz latites and highly alkalic igneous intrusive rocks and associated lavas of middle Eocene age (Carey, 1954b) occur southeast of the Gas Hills uranium district but are not in contact with the Wind River Formation at the surface. The White River Formation of Oligocene age overlies the

\footnotetext{
1 The name Rattlesnake Range was changed to Rattlesnake Hills by the U.S. Board on Geographic Names after this report was prepared.
}

Wagon Bed; however, in two places in this area, south of the Dutton Basin anticline and south of Coyote Springs, fine-grained sedimentary rocks of the White River Formation are in contact with the upper part of the Wind River Formation where two valleys were eroded through the Wagon Bed Formation (Zeller and others, 1956). Conglomerate and sandstone of Miocene age overlie the White River Formation. The total thickness of the post-Wind River rocks is about $800-1,000$ feet.

All along the south edge of the Wind River Basin, the top of the Wind River Formation typically lies near the base of a steep escarpment which is mostly 500700 feet high and which is capped by the conglomerate and sandstone of Miocene age (fig. 4). This escarpment is the most conspicuous feature of the region, and its top, the Beaver Divide, is the southern physiographic boundary of the Wind River Basin. A flat to gently southward-sloping surface south of this divide, underlain mostly by rocks of Miocene age, is known as the Sweetwater Plateau. Knobs of predominantly granitic rocks of Precambrian age protruding from less than 100

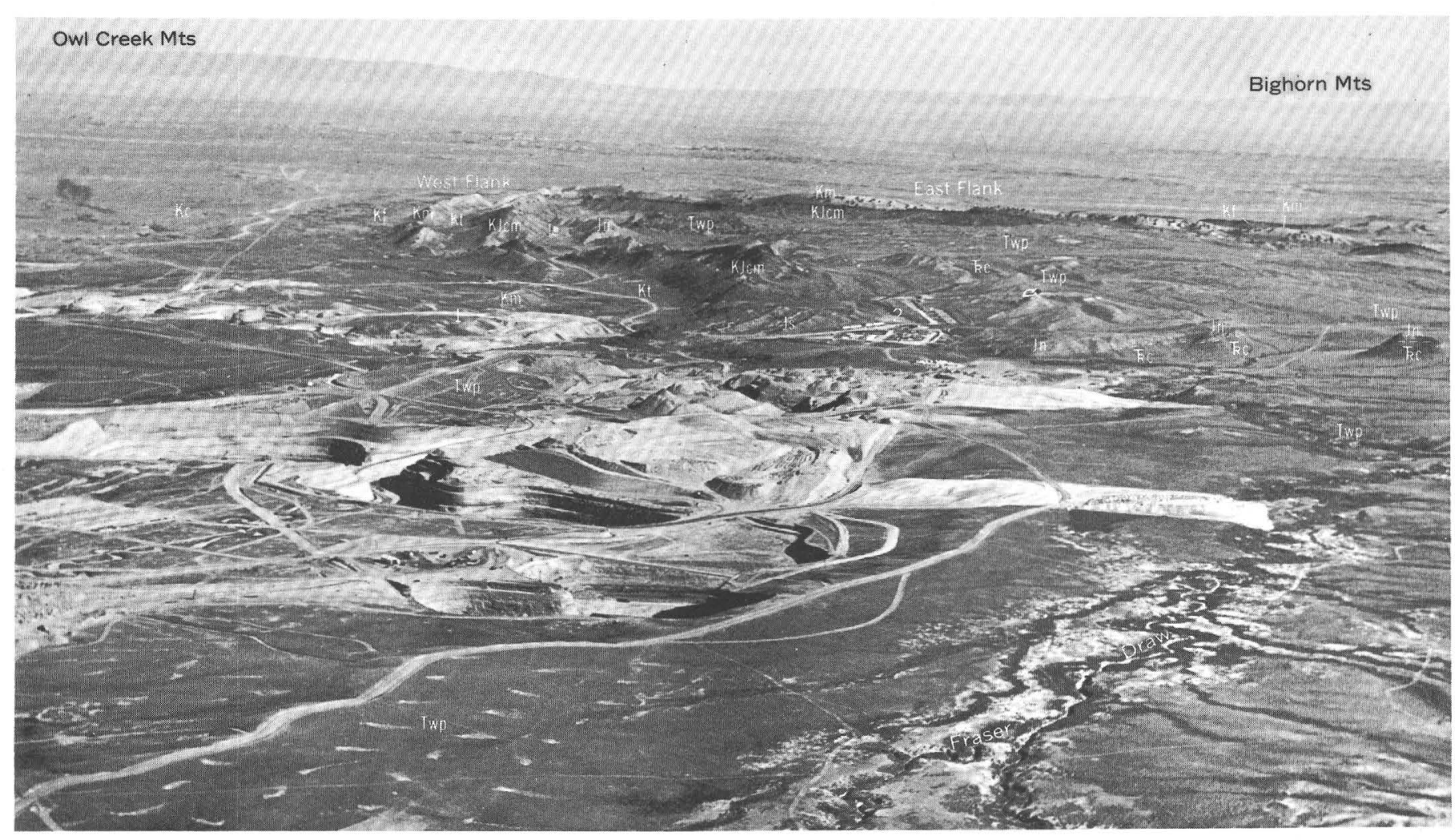

FTgURE 3.-Exhumed ridges and valleys of breached Dutton Basin anticline and large open-pit uranium mines in the Puddle Springs Arkose Member near the west flank. Note relief on pre-Tertiary rocks with respect to the Wind River Formation. View northeast from about east line sec. 3, T. 32 N., R. 90 W. Twp, Puddle Springs Arkose Member of the Wind River Formation; Kc, Cody Shale; Kf, Frontier Formation; Km, Mowry Shale; Kt, Thermopolis Shale; KJcm, Cloverly and Morrison Formations, undifferentiated; Js, Sundance Formation; Jn, Nugget Sandstone; Kc, Chugwater Formation; I, Lucky Me discovery hill ; 2, Lucky Mc Camp. Aerial photograph courtesy of Page Jenkins. 


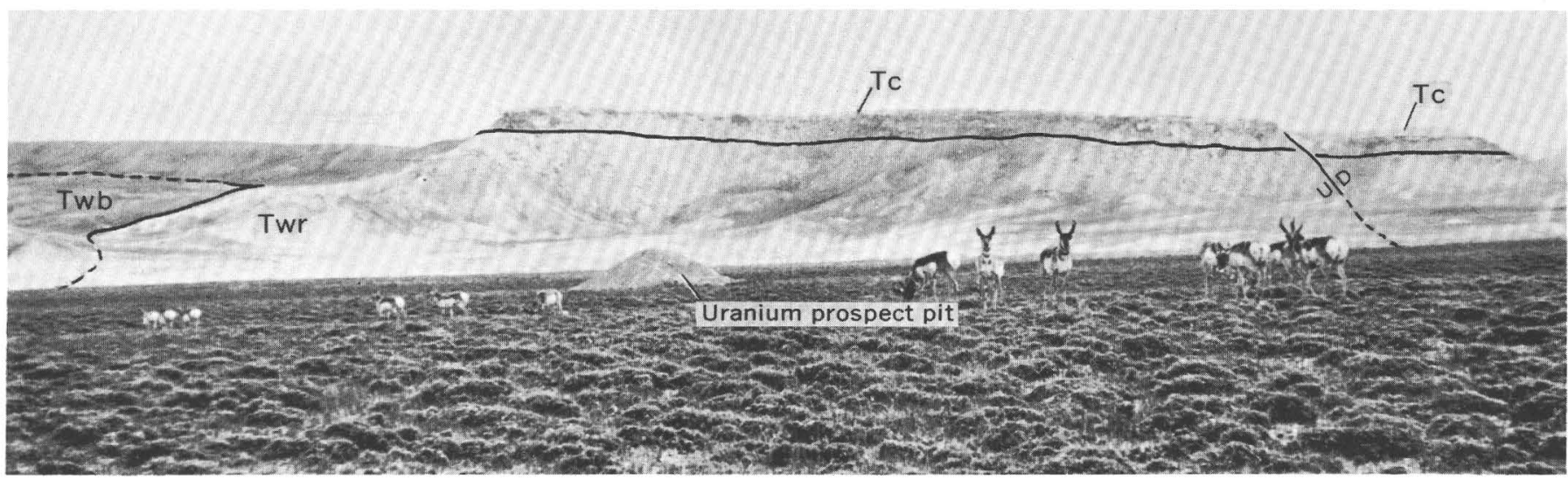

Figure 4.-Beaver Divide escarpment southeast of Coyote Springs. View east from SE1/4 sec. 26, T. 32 N., R. 91 W., showing the thick section of White River Formation (Twr) in a paleovalley eroded through the underlying Wagon Bed Formation (Twb). Tc, basal conglomerate of Miocene rocks that forms the cap for the Beaver Divide along most of its extent. Smooth surface in foreground is one of the common northward-sloping thinly veneered Pleistocene surfaces that truncate the Wagon Bed and Wind River Formations near the south-central edge of the Wind River Basin.

to as much as 1,800 feet above the plateau are known as the Granite Mountains, but they have also been called the Sweetwater rocks, particularly in older reports and in writings of the 19th century pioneers. Hard dark hornblende schist composes Black Mountain, and schist, gneiss, and other metamorphic rocks are common southwest of the area.

The Granite Mountains, the core of the Sweetwater uplift, were much higher and the total relief greater during Wind River time than at present. Subsidence of the Sweetwater uplift in post-middle Miocene time (Knight, 1954, p. 36), however, resulted in the present low relief of the mountains, as well as the southward dip of the originally northward-dipping Tertiary rocks in and south of the Gas Hills uranium district (fig. 5). The subsidence also caused east-trending normal faults, with throws of as much as 350 feet, to form in the area of southward-dipping Tertiary rocks.

The Wind River Formation and overlying rocks have been removed by erosion over most of the area just north of the uranium district (pl. 1), along the easttrending crest of a very low broad anticline (J. L. Weitz, oral commun., 1954) in the Tertiary rocks. The precise axis of this anticline cannot be delineated, but northward a few miles from about the pipeline road beds of the Wind River Formation are mostly horizontal, whereas along the north edge of the map area, they dip very gently northward. This report is primarily concerned with stratigraphy of the Wind River Formation south of the axial area.

\section{WIND RIVER FORMATION HISTORY OF STRATIGRAPHIC TERMS}

The Wind River Formation of early Eocene age is confined to the Wind River Basin and a few other areas in Wyoming (Love and others, 1955). The Indian Meadows Formation, below the Wind River Formation in the northwestern part of the basin, is the only other lower Eocene formation recognized in this basin (Keefer, 1957, p. 188).

According to Nace (1936, p. 160), "Wind River was first used as a formation name by Meek and Hayden in 1861, in their tabular 'general section of the Tertiary rocks of Nebraska (territory)" " in which the term "Wind River deposits" was used. Hayden, however, (1878, p. 831) wrote that the Tertiary strata "filling up the Upper Wind River Valley" were described by him "in 1859 in detail" and that they were named by him the Wind River Group. He said that this group "covers a broad area in this region, extending from the source of the Wind River to the Sweet Water Mountains, south, more than 100 miles, and west an average width of 1 to 5 miles" and that the "aggregate thickness of this group cannot be less than 5,000 feet." The locality given by Meek and Hayden (1861, p. 433) was the "Wind River Valley" and "also west of Wind River Mountains," and apparently all their descriptions of this formation in the Wind River Basin pertain only to the west edge of the basin. They stated that the stratigraphic position of the Wind River deposits was doubtful because they had not seen them in contact with any other Tertiary formations, but they placed them between the Fort Union and the White River Formations.

In the western part of the basin, the Wind River Formation was referred to as the "Wind River group" by Hayden in 1859 (Cope, 1882, p. 183), Meek and Hayden (1861, p. 446-447), Hayden (1862, p. 310, 311), Meek (1876, p. 11 of "Introduction"), and St. John (1883, p. 259$)$. 

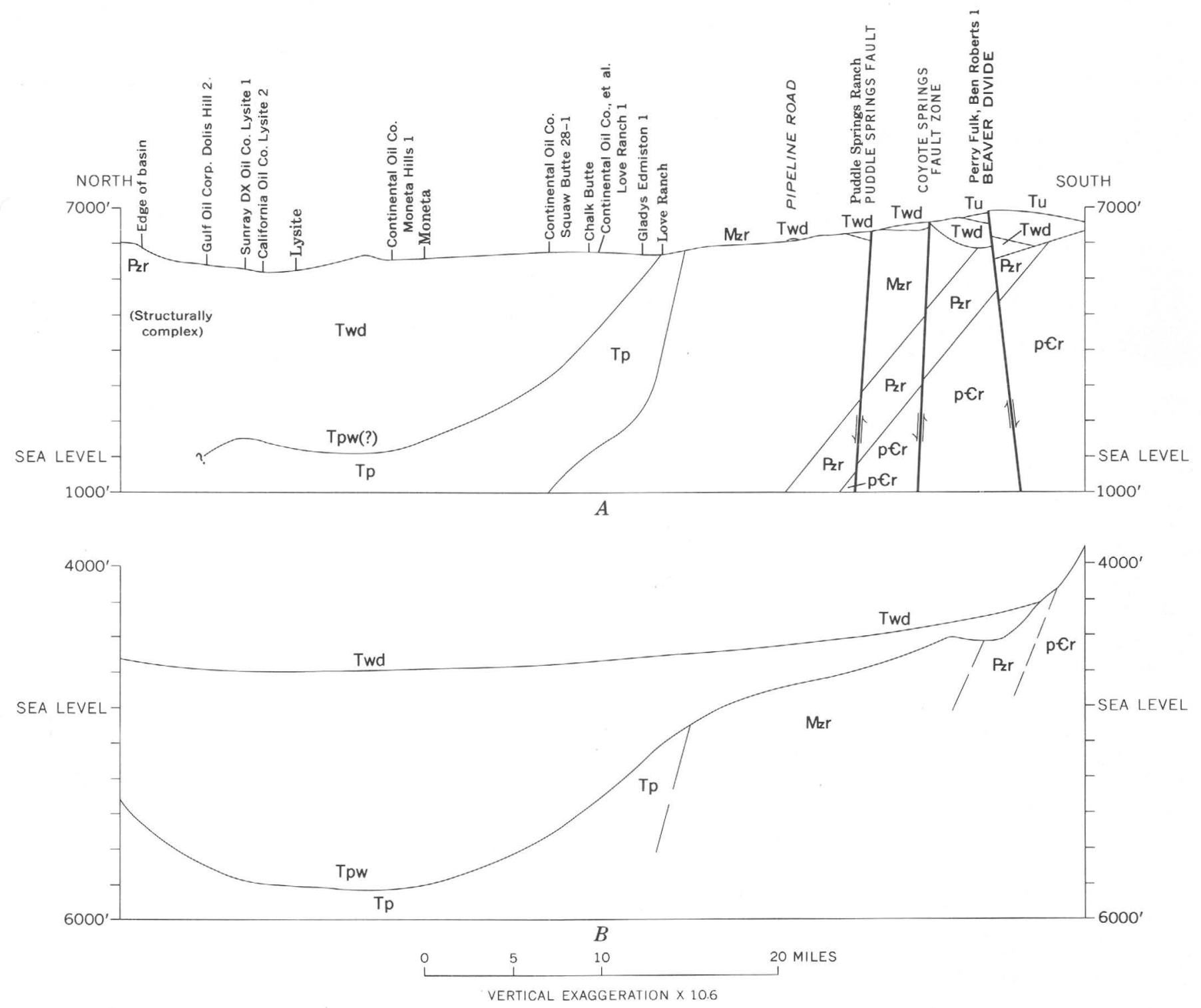

Figure 5.- Section across the Wind River Basin comparing thickness and geologic setting of the Wind River Formation in south-central and central parts of the basin. Units are $p C_{r}$, Precambrian rocks; Pzr, Paleozoic rocks; Mzr, Mesozoic rocks; $T p$, Fort Union Formation of Paleocene age; Tpw, pre-Wind River rocks of earliest Eocene age, posisibly present in deepest parts of basin but not recognized as a unit distinct from Wind River Formation by oil company geologists; Twd, Wind River Formation of early Eocene age; and Tu, undivided middle Eocene to Miocene rocks. (Quaternary deposits are thin and are not differentiated.) $A$. Conditions at the present time; drill holes penetrating the Wind River Formation and geographic locations are projected into the section from distances of generally less than 2 miles. $B$. Postulated conditions at the end of early Eocene time; altitudes are based on a hypothetical altitude of 1,000 feet above sea level for the surface of the deepest part of the basin.

Endlich $(1878,1879)$ used the term "Wasatch Group" for the present Wind River and Wagon Bed Formations at the foot of the Beaver Divide escarpment in the southwestern part of the basin and in the Muskrat Basin (pl. 1). In terming these rocks "Wasatch," Endlich was undoubtedly influenced by his previous work south of the $43 \mathrm{~d}$ parallel where typical Wasatch strata occur. $\mathrm{He}$ made no mention of their relation to the "Wind
River deposits" of Hayden, although the beds in the southwestern part of the basin which he mapped as Wasatch probably were included in Hayden's "Wind River deposits."

Granger (1910, p. 236, 247) called the Wind River rocks both a formation and a group. Sinclair and Granger $(1911$, p. 104) proposed the terms "Lysite Formation" (below) and "Lost Cabin Formation" (above) of 
the Wind River Group primarily on the basis of fossils found in two faunal zones near villages of the same names in the northeastern part of the basin (fig. 1). They also indicated some lithologic differences between the two units. The northeastern part of the Wind River Basin has the best known sections of the Wind River Formation as a result of fossil-collecting trips by at least 13 persons during more than 22 separate excursions between 1880 and 1948 (Tourtelot, 1948, p. 112) and later work by Tourtelot (1953). Osborn (1929) divided the Wind River Formation into "Wind River A" for the Lysite and "Wind River B" for the Lost Cabin. Simpson $(1933$, p. 101, 102) used the terminology of Sinclair and Granger (1911). Wilmarth (1938, p. 2349) stated that the definition of the Wind River as a formation that has two faunal zones (the "upper two faunal zones of Wasatch formation" by Osborn (1929)) "is present approved definition of U.S. Geological Survey."

Wood (1941, p. 23) wrote that although the "Lost Cabin member ***" is "considered a faunal zone by Wilmarth (1938), following Osborn (1929), it is, unquestionably, a valid, mappable lithologic unit (Simpson, 1933; Wood and others, 1936)." Their remarks also applied to the Lysite Member. Tourtelot (1948, p. 114) stated that "Although the lithologic differences between the rocks of the Lysite and Lost Cabin units were described, most later workers neglected these lithologic differences and considered the names to represent only faunal zones (Wilmarth, p. 1219-1220 and p. 12431244)." According to Tourtelot (1948, p. 114), the opinion of Wood and others "was found to be correct in recent work of the Geological Survey, and Lysite and Lost Cabin have been accepted as lithologically distinct members of the Wind River formation." Because of abrupt facies changes, however, these members cannot be mapped more than a few miles from the type localities (Tourtelot, 1953, geologic map) and "the names Lysite and Lost Cabin should not be applied to lithologic units in places other than along the southern margin of the Big Horn Mountains" (Tourtelot, 1948, p. 118). W. R. Keefer (written commun., 1962) extended the names into the eastern part of the basin on what he believes is valid evidence.

Until the work by this writer (Soister, 1966c), no members of the Wind River Formation except the Lysite and Lost Cabin had been designated, although many localities where the formation occurs include two or more lithologically different units (Tourtelot and Thompson, 1948 ; Thompson and White, 1952b; Murphy and Roberts, 1954; Troyer and Keefer, 1955; Murphy and others, 1956; Zeller and others, 1956; Keefer, 1957, p. 189 ; Rich, 1962). Inasmuch as sediment source areas and depositional environment varied from place to place within the basin, it is doubtful that any member can be recognized over a major part of the basin. Variations laterally and vertically are so pronounced that composite stratigraphic sections, when applied to large areas, can give a false picture of the formation.

Endlich $(1878,1879)$ first mentioned strata of the Wind River Formation in the area of the present report. No other geologists called these beds Wasatch as Endlich did, although Hxyden (1878) recognized that Wasatch was replacing Wind River and other early names in geologic reports of the region from Wyoming to New Mexico. In the south-central part of the Wind River Basin, the contact of the Wind River Formation with the overlying Wagon Bed Formation is based on the work of Van Houten $(1950,1954)$, who mapped along the Beaver Divide escarpment and provided the link between the fossil localities in the Beaver Creek area and the unfossiliferous beds of this area.

In the area of this report, the Wind River Formation is divided into (1) the lower fine-grained member, 0 130 feet thick, (2) the Puddle Springs Arkose Member (Soister, 1966c), generally 400-800 feet thick, and (3) the upper transition zone, generally 50-100 feet thick. Two persistent conglomerate beds have been mapped in the Puddle Springs and have been designated the Dry Coyote Conglomerate Bed and the Muskrat Conglomerate Bed (Soister, 1966c); another persistent unit, the East Canyon Conglomerate Bed (Soister, 1966c) was traced mostly in the subsurface. A prominent carbonaceous shale and impure coal zone at the top of the lower fine-grained member was traced by $\operatorname{logs}$ of drill holes and is informally known as the central carbonaceous zone.

\section{PALEONTOLOGY AND STRATIGRAPHIC POSITION}

Paleontologic work on the Wind River Formation in the Wind River Basin through 1929 was outlined by Nace (1936, p. 170-175), and that in the northeastern part of the basin was outlined by Tourtelot (1948). Van Houten (1945) reviewed the early Eocene mammalian faunas and listed fossils that occur mainly near Lysite and Lost Cabin in the highly fossiliferous northeastern part of the basin. The Wind River Formation of present concepts is considered to include the Lysite (below) and Lost Cabin faunal zones of middle and late Wasatch age (Van Houten, 1945, p. 241).

The latest comprehensive paleontologic report is by Kelley and Wood (1954), who restudied a total of 465 identifiable mammal specimens from the type area of the Lysite Member which were collected by F. B. Loomis in 1904, A. E. Wood in 1948, and D. R. Kelley in 1951.

Plant fossils are common in the numerous carbonaceous beds in the Wind River Basin (Collier, 1920, p. 78; 
Berry, 1930, p. 55-57; Wood and others, 1936, p. 394; Van Houten, 1957, p. 83; Tourtelot and Thompson, 1948; Van Houten, 1955 , p. 5, 6). They are less diagnostic of age than are the mammal fossils, and a slightly younger age is usually cited by the paleobotanists than by the vertebrate paleontologists.

In $1955, \mathrm{H}$. D. Zeller collected numerous turtle bone fragments and other fossil remains at Chalk Butte (fig. 1), sec. 11, T. 35 N., R. 91 W., 10 miles north of the principal area of this report, in strata that may be approximately equivalent to the lower fine-grained member. C. L. Gazin (written commun. to H. D. Zeller, Apr. $26,1956)$ reported as follows on some of this collection:

The material from the south-central part of Wind River Basin, south of Moneta, Wyoming, includes several hundred fragments of bone lacking any diagnostic significance. Among these, however, are a few fragments of teeth which are surely Coryphodon sp. One tooth fragment appears to be from the lower series of a creodont, possibly Oxyaena sp. These materials have no age significance other than Wasatchian or lower Eocene.

Except for leaves of possible Green River age 60 feet below the top of the formation (Van Houten, 1955, p. $5-6 ; 1957$, p. $83 ; 1964$, p. $31-32)$, no other diagnostic fossils have been found in the south-central part of the Wind River Basin, and the age of the Wind River Formation here is inferred by correlations with fossiliferous beds in other parts of the basin.

Poorly preserved leaves from carbonaceous shale about 60 feet below the top of the formation in the SW $1 / 4$ NE $1 / 4$ sec. 27 , T. 33 N., R. 89 W., were reported by Van Houten $(1964$, p. 32) ; these were identified by R. W. Brown as follows: Quercus castaneopsis Lesquereux, Zizyphus cinnamomoides Lesquereux, Zelcova nervosa (Newberry) Brown, Sparganium antiquum (Newberry) Berry, Leguminosites sp., Aralia sp., Ulmus sp. Of this collection, Van Houten $(1964$, p. 32) wrote that

The four identified species, two of which are also present in the Big Sand Draw collection, are characteristic of leaves in the Green River Formation. The same species are found in northwestern Wyoming in or below beds yielding early Eocene mammalian fossils. On this basis, all the Wind River Formation in the map area is tentatively assigned an early Eocene age.

This upper part of the Wind River Formation is in or equivalent to the upper transition zone, and the contact between lower and middle Eocene may lie just above this zone.

The major unit of the Wind River Formation in this area, the Puddle Springs Arkose Member, is probably largely or entirely of Lost Cabin age. The lithologic break between the Puddle Springs and the underlying fine-grained member in the central part of the report area may possibly correspond to the break between the Lysite and Lost Cabin Members about 30 miles due north. This would make the lower fine-grained member in this area of Lysite age. However, there can be only speculation as to the exact age of the units of the Wind River Formation in the south-central part of the Wind River Basin until diagnostic fossils are found in this area.

\section{GENERAL LITHOLOGY AND THICKNESS}

The lower fine-grained member is mainly composed of partly variegated siltstone and claystone, very fine grained sandstone, and a few carbonaceous shale beds; it also has a thin discontinuous nonarkosic conglomerate at or very near the base. The Puddle Springs Arkose Member is a thick mass of yellowish-gray arkose with some boulder conglomerate beds and includes minor amounts of fine-grained sandstone, siltstone, claystone, and carbonaceous shale beds and lenses. The upper transition zone consists of interbedded arkose similar to beds in the Puddle Springs and drab tuffaceous mudstone beds similar to those in the overlying Wagon Bed Formation.

The thickness of the Wind River Formation varies with the irregularities of the erosion surface on which the formation was deposited. For example, the lower fine-grained member and much of the Puddle Springs Arkose Member are absent where the formation laps onto high ridges of pre-Tertiary rocks on the Dutton Basin anticline. The lower fine-grained member is not present at the surface east of this fold but may occur in the subsurface just west of the Rattlesnake Range. Thinning of the lower part of the Puddle Springs Arkose Member by overlap on the pre-Wind River rocks on the north flank of the Sweetwater uplift is illustrated in figure 6. Thinning and thickening of the upper transition zone is dependent on deposition and nondeposition or contemporaneous removal by erosion of tuffaceous mudstone beds; the zone apparently thickens westward.

Typical thickness of the lower fine-grained member is about 120 feet; however, in the area between the Dutton Basin anticline and Willow Springs Draw, this member intertongues with the Puddle Springs Arkose Member for 100 feet higher. The Puddle Springs averages about 500-600 feet in thickness over the area from Muskrat Creek to East Canyon Creek, but has a composite thickness in the Puddle Springs quadrangle of at least 800 feet. The member thins southward by overlap on older rocks on the north flank of the Sweetwater uplift, so that drill holes penetrating the entire thickness of the member (for example, C9, D6, F7) show less than this composite thickness. The member was originally thickest probably in the vicinity of the pipeline road west of the Dutton Basin anticline, but it has been completely removed by Quaternary erosion there. 


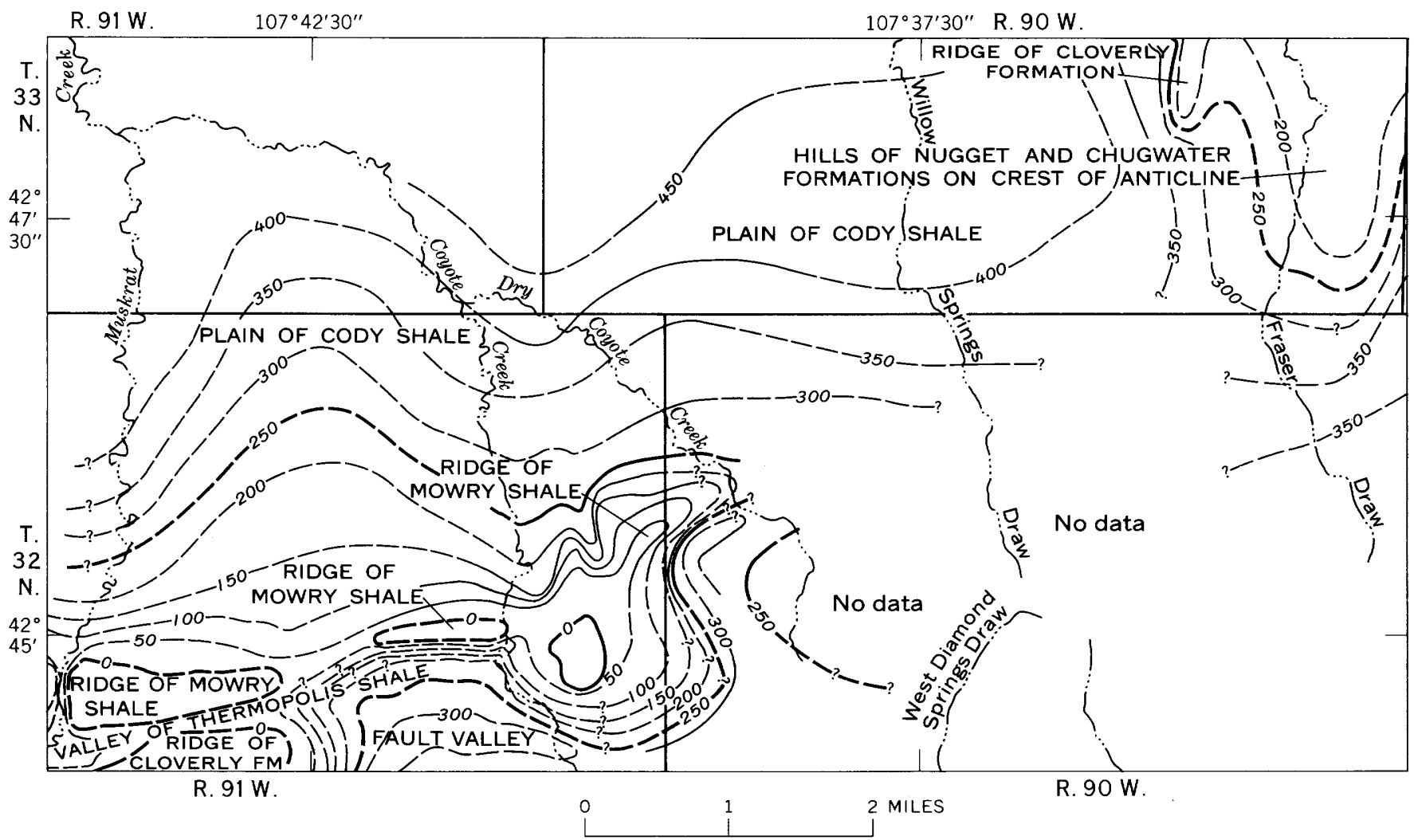

FIGURE 6.-Isopach map showing original thickness, in feet, of Wind River Formation below the top of the Dry Coyote Conglomerate Bed in the central part of the area and also physiographic features of pre-Tertiary rocks that affected deposition of the sediments. Thickness lines are solid in areas of best control, dashed where uncertain, queried where very uncertain. Known or suspected landforms during part of Wind River time are indicated by place names such as ridge of Mowry Shale. Present-day streams are shown.

The upper transition zone is generally $50-100$ feet thick but is locally absent where red-banded claystone and siltstone or massive arkosic sandstone beds of the Wind River Formation without the drab mudstone beds lie below the marker beds of the Wagon Bed Formation.

\section{OCCURRENCE AND FACIES RELATIONS}

The most conspicuous lateral variations in the Wind River Formation near the south-central edge of the Wind River Basin are east-west facies changes (fig. 7). North-south variations are not very apparent because the formation has been almost entirely removed by erosion from a large area just north of the basin edge (pl. 1). There is sufficient evidence left, however, to show that the coarser basinedge deposits interfinger northward with finer grained basin deposits.

Coarse deposits of arkose along the south edge of the Wind River Basin from the Conant Creek anticline (6 miles west of area of map, pl. 1) to the Rattlesnake Range are assignable to the Puddle Springs Arkose Member; however, because these coarse deposits interfinger extensively with the more normal finegrained variegated Wind River beds west of Muskrat
Creek and also just west of the Rattlesnake Range, members cannot generally be defined in these areas. Several miles north of the pipeline road the Wind River Formation consists of predominantly fine-grained variegated beds with coarse arkosic sandstone beds that are undoubtedly tongues from the Puddle Springs Arkose. This member is not differentiated north of the road except in the eastern part of the area, north of the Rattlesnake Range.

The lower fine-grained member is mapped only in the area between Muskrat Creek and the Dutton Basin anticline, where the overlying Puddle Springs Arkose Member contains relatively few fine-grained beds. However, variegated strata identical to the lower finegrained member occur throughout the formation east, west, and north of the massive wedge of arkose; these fine-grained strata, above the horizon of the designated contact of the two members, have interbedded arkosic sandstone beds that are tongues from the Puddle Springs Arkose Member.

Some contacts between units of the Wind River Formation are readily mappable, whereas others are difficult to place accurately. The contact between the 

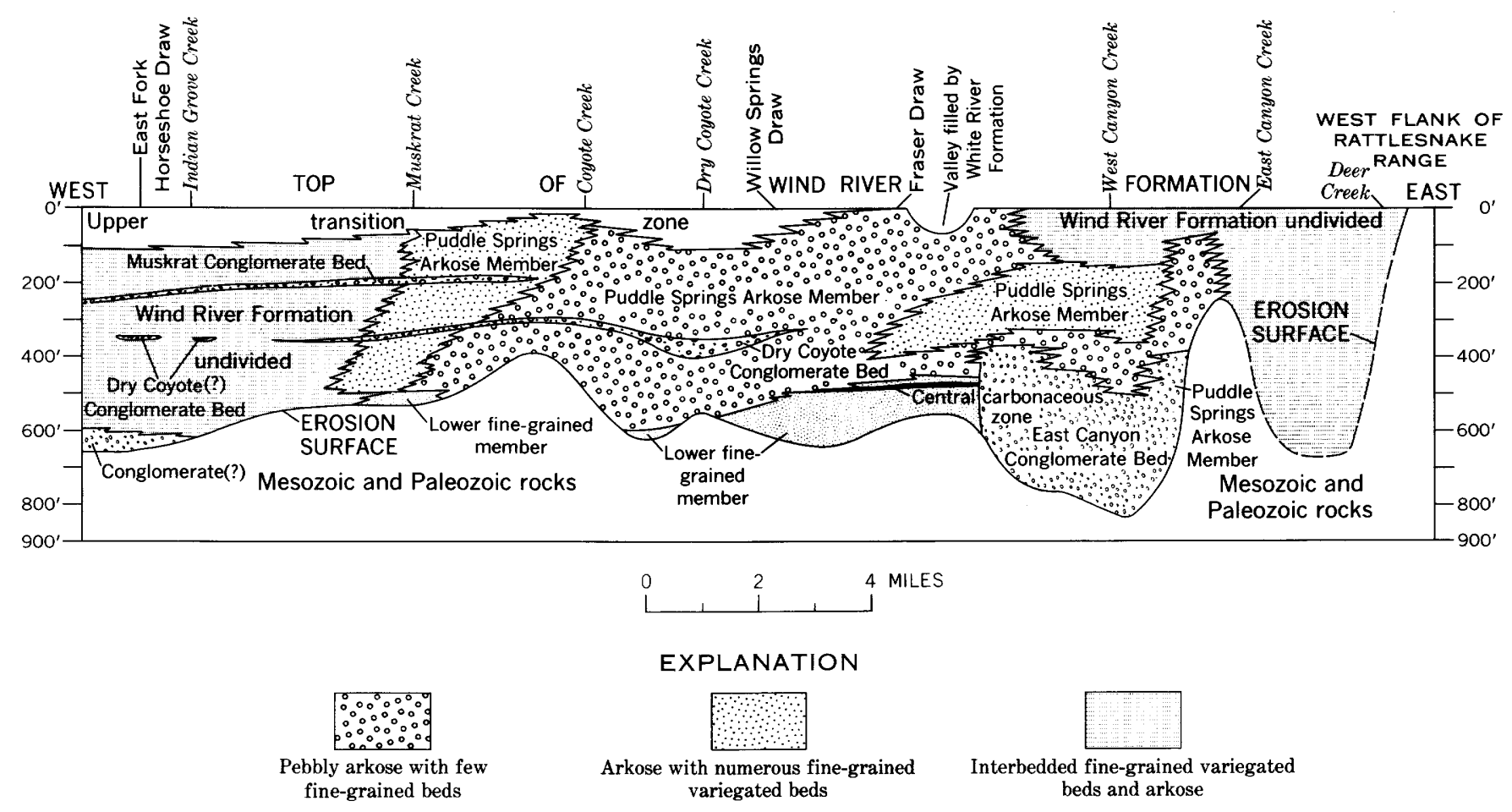

FIGURE 7.-Diagrammatic restored stratigraphic section of Wind River Formation near south-central edge of Wind River Basin showing lithologic units and facies changes. Line of section is shown in figure 2.

lower fine-grained member and the Puddle Springs Arkose Member was mapped from the Dutton Basin anticline to just west of Muskrat Creek (Zeller and others, 1956; Soister, 1967b). The central carbonaceous zone, except for a few tens of feet of possible outcrop, occurs only in the subsurface and in the face of some open-pit uranium mines. The East Canyon Conglomerate Bed occurs mostly in the subsurface; where it crops out, it grades upward into interbedded sandstone and conglomerate. The Dry Coyote Conglomerate Bed and the Muskrat Conglomerate Bed, in the western part of the area, have been mapped (Soister, 1966a, b; $1967 \mathrm{a}, \mathrm{b})$. Because of interbedding, the base of the upper transition zone is gradational and was not mapped.

These lateral changes in the Wind River Formation, especially in the Puddle Springs Arkose Member, allow the main area of this report to be divided into seven subareas, identified by letters A-G (fig. 2; pls. 2, 3, 4). Almost all the stratigraphic study was done in these lettered areas because they include the thickest exposed sections, nearly all the drill holes, and all the known uranium deposits. Certain lithologic characteristics and lateral variations cross the boundaries shown, and they are described in the following paragraphs. Six other subareas, identified by Roman numerals I-VI, are briefly discussed. In areas I to III the formation has been removed by erosion or generally less than 100 feet of it remains after Quaternary erosion. In areas IV and $\mathrm{V}$ the formation is buried by younger rocks, and only a few holes had been drilled at the time of this study. The formation was not studied in area VI, but brief observations were made.

In the western part of the area, over all the Rongis Reservoir SE quadrangle except about a 2-mile-wide strip along the south boundary, all but about 100-200 feet of the Wind River Formation has been removed by erosion (Soister, 1967b). The lower fine-grained member is about 100 feet thick in the Muskrat gas field and the typical green- and red-banded beds of this member are present over much of the northern part of the quadrangle at the base of the formation. Coarse arkosic sandstone is present at the base of the formation in some places, especially south of the pipeline road, but over most of the quadrangle fine-grained beds are interbedded with channel sandstone beds and with coarse arkosic sandstone typical of the Puddle Springs Arkose Member. Fine-grained beds are absent at the base of the formation in some places and are only a few feet thick in others.

Upward in the section to the south, along the southern part of the quadrangle and into the adjacent Muskrat Basin quadrangle (pl. 2), beds of fine- to mediumgrained sandstone and green- and red-banded siltstone and claystone typical of the lower fine-grained member are interbedded with coarse arkosic beds typical of the Puddle Springs Arkose Member (Soister, 1966a). 
Similar green- and red-banded beds are present above the Dry Coyote(?) Conglomerate Bed and upward to near the base of the Muskrat Conglomerate Bed. Some interbedding continues east of Muskrat Creek, and in the northwestern part of the Coyote Springs quadrangle (fig. 2, area B; Soister, 1967a) fine-grained green- and red-banded beds occur above the Muskrat Conglomerate Bed.

Lenses of the Dry Coyote(?) Conglomerate Bed apparently become less numerous to the west. The sheetlike Muskrat Conglomerate Bed becomes more prominent westward, however, and above it, west of Muskrat Creek, the Wind River Formation is almost entirely fine grained and mostly drab colored. Thin red bands are present within about 108 feet of the top of the formation at the west edge of the area. The transition zone thins from this area to the east.

The lower fine-grained member is mostly $100-120$ feet thick in the southeastern part of the Rongis Reservoir $\mathrm{SE}$ and northeastward over much of the Puddle Springs quadrangle (Soister, 1967b). Northward along the boundary of these quadrangles (fig. 2, area II), thick channel sandstone beds lie at the base of the formation or above a thin squence of the lower fine-grained member. In most places, similar, but thinner, sandstone beds occur at the contact of this member and the Puddle Springs Arkose Member, and a few occur above or below the contact. Along Muskrat Creek a channel sandstone, thickest in secs. 21 and 28, T. 33 N., R. 91 W., probably represents a main stream channel of about early Puddle Springs time.

In the area between Muskrat Creek and Coyote Creek (pl. 2), the Puddle Springs Arkose Member has more coarse-grained material than in the area to the west and less than in the area to the east. Variegated beds and arkose are interbedded in the northwest quarter of the Coyote Springs quadrangle (Soister, 1967a).

Eastward from Coyote Creek (fig. 2, area C; pl. 3) the Puddle Springs Arkose Member is mainly very coarse conglomeratic arkosic sandstone and conglomerate with minor beds of silt and clay and very few carbonaceous beds. The Muskrat Conglomerate Bed apparently pinches out just west of Coyote Creek. The Dry Coyote Conglomerate Bed is the most prominent in this area and is a valuable key bed; it pinches out just east of Willow Springs Draw but thickens to the southeast. The Wind River Formation thins to the south and onto the ridges of pre-Tertiary rocks below this bed. The transition zone at the top of the formation in area $\mathrm{C}$ is generally thinner than it is west of Muskrat Creek and also contains more coarse-grained arkosic sandstone.

In the central part of the area (pl. 3 , area D), the typical lower fine-grained member, about 120 feet thick, is mostly in the subsurface, but it is exposed eastward from Sarcophagus Butte. The central carbonaceous zone (fig. $11 ; \mathrm{pl} .3$ ), the only fairly persistent traceable unit known here, occurs at or just below the top of this member over most of this area but is in a part of the member that intertongues with the Puddle Springs Arkose Member. The west edge of this carbonaceous unit approximately coincides with the east edge of the Dry Coyote Conglomerate Bed, but lies about 200 feet lower in the section. The east edge of this carbonaceous unit is close to and may even coincide with the west edge of the East Canyon Conglomerate Bed south of the Dutton Basin anticline. Along with other beds of the lower fine-grained member, it may have been deposited farther east, as indicated by its thickness in drill holes near its east edge, but virtually all the fine-grained beds in the area to the east were probably removed by erosion that immediately preceded deposition of the gravel forming the East Canyon Conglomerate Bed. The southern limit of the central carbonaceous zone is not known because of the lack of drill-hole data. It is doubtful, however, that the zone could extend more than 1 mile south of the boundary indicated in figure 11.

The lower part of the Puddle Springs Arkose Member in this central area (fig. 2, area D; pl. 3) contains interbedded fine-grained beds with a few red bands and coarse-grained conglomeratic arkosic sandstone. This sequence probably represents a transition upward from the lower fine-grained member to the Puddle Springs Arkose Member. In fact, in the northwestern part of area $\mathrm{D}$ (sections D1-D4) the designated contact between these members is arbitrary because of interbedding of fine-grained and coarse arkosic materials. The rest of the Puddle Springs is mainly very coarse to mediumgrained and partly conglomeratic arkosic sandstone with some finer conglomerate beds. Unlike the areas to the west and to the east, however, it has no cobble or boulder conglomerate beds. The typical transition zone at the top of the formation is very thin or absent here.

Very little work has been done in the area between the east and west flanks of the breached Dutton Basin anticline (fig. 2, area E; pl. 4). Exposures are poor and very little drilling was done before or during the fieldwork of the U.S. Geological Survey. Coarse arkosic beds of the Puddle Springs Arkose Member lie between exhumed ridges of Mesozoic rocks which form the flanks of the anticline (fig. 3). Here, at least one thick carbonaceous shale occurs a few feet above the Nugget Sandstone (stratigraphic sections E2 and E3), and other beds of the member lie on the Sundance, Nugget, and Chugwater Formations. Coarse arkosic sandstone beds with minor interbedded siltstone and claystone beds 
comprise most of the strata. These sandstone beds were deposited in channels of streams that flowed partly along strike valleys cut in soft formations, such as the Thermopolis Shale, and through water gaps cut through hogbacks of the Mowry, Cloverly, and other formations. Most of the Wind River beds remaining here are probably near the middle of the Puddle Springs Arkose Member.

In the east-central part of the area (fig. 2 , area $\mathrm{F}$; pl. 4 ), the lower fine-grained member has not been recognized. A thick coarse boulder conglomerate, the East Canyon Conglomerate Bed, occurs at and near the base of the formation. Some sediments of the lower finegrained member may have been deposited in this area and then removed by erosion before deposition of the coarse gravel. The nature of the buried contact between this coarse part of the formation and the finer grained beds to the west is not known, but it may be mainly a channeling relationship in the lower 100-200 feet of the formation and an intertonguing relationship above.

Above the East Canyon Conglomerate Bed, the Puddle Springs Arkose Member is very coarse grained and conglomeratic, and it contains a few thin beds of siltstone and claystone. The upper part of the formation, as determined by drill holes in the Thunderbird graben (Zeller, 1958, p. 106, 107), consists of more than 200 feet of fine-grained sediments including thin red beds. Although some of these beds occur at the same stratigraphic position as the upper transition zone, they are not considered by the writer to be part of that zone because (1) these beds are probably not tuffaceous (Van Houten, 1955, p. 12), whereas the typical transition zone is, (2) unlike the drab-colored transition zone, red beds are present, and (3) similar fine-grained red beds occur throughout most of the formation in other areas. Perhaps the transition zone owes the drab color and typical mudstone mainly to its tuffaceous material, which increases to the west (Van Houten, 1955, p. 12). The finegrained red-banded beds high in the formation in this part of the area probably are typical basin sediments, similar to the lower fine-grained member rather than to the overlying Wagon Bed Formation. They apparently thicken to the east and north toward deeper parts of the basin and interfinger southward with coarse piedmont sediments of the Puddle Springs Arkose Member which thicken to the south and west.

In the eastern part of the area, between Black Mountain and the Rattlesnake Range (fig. 2, area G; pl. 4), less is known about the formation, partly because of the scarcity of drill-hole information. Possibly there is a typical lower fine-grained member at the base of the formation in parts of this area. Where the formation crops out or has been drilled, it is composed mainly of greenish and thin red beds of siltstone and claystone interbedded with thin beds of fine- to medium-grained sandstone and coarse-grained to conglomeratic arkosic sandstone and a few thin small-pebble or granule conglomerates. At least one thick carbonaceous shale and a few thin ones are known.

This eastern part of the area is like the western part in that beds similar to those in the lower fine-grained member are interbedded with beds of the Puddle Springs Arkose Member, and it is like the central part in that a thick carbonaceous zone is present in at least part of the area. Some pebble or cobble conglomerate that was noted in drill holes may represent channels from the southeast. More coarse material at the northwest end of the Rattlesnake Range may be a transition between the very coarse sediments to the west and the finer sediments between Black Mountain and the Rattlesnake Range. Much of the coarse material was probably carried to the northeast around the north end of the Black Mountain highland area (pl.4; fig. 15).

\section{CORRELATIONS}

Precise correlation of strata of the Wind River Formation in this area with strata in other areas is not possible because of considerable differences in the sources of sediments and the depositional environments in the Wind River Basin. In some places, the lower part of the formation is fine grained and variegated, and the upper part is coarser grained and arkosic (Zeller and others, 1956; Rich, 1962). In other places, the converse is true (Tourtelot and Thompson, 1948; Troyer and Keefer, 1955). In most places around the margins of the basin, however, thick coarse beds are interbedded with fine variegated beds (Keefer, 1955; 1957, p. 189; Murphy, 1956 ; Murphy and others, 1956 ; this report). Coarsegrained beds near the margin of the basin interfinger with finer grained beds deposited farther out in the basin (Love, 1939, p. 107; Tourtelot and Thompson, 1948; Tourtelot, 1953; Keefer, 1957, p. 189). Interfingering also occurs parallel to the margin of the basin owing to (1) ridges or slopes of Paleozoic or Mesozoic rocks acting as barriers to prevent or impede the transportation of coarse materials into some localities and (or) (2) the location of the highest mountains that provided sediments in Wind River time. Such interfingering parallel to the margin of the basin, together with cut-andfill relations, is responsible for the east-west facies changes in the south-central part of the basin.

Strata in the south-central part cannot be directly correlated with beds in the eastern part of the Wind River Basin because the Rattlesnake Range formed a highland between these two areas throughout Wind River time. In the eastern part of the basin, the Wind 
River Formation consists of a lower fine-grained facies and an upper coarse-grained arkosic facies (Rich, 1962). Rich divided his lower fine-grained facies into a lower variegated fine-grained sequence and an upper drab fine-grained sequence that contains lenticular arkosic sandstone beds. In the western part of the area studied by Rich, some of these sandstone beds are quite similar to those near Muskrat Creek in the Puddle Springs quadrangle (see p. A26). Some of the persistent sandstone beds in the Ervay Basin quadrangle are equivalent to at least the lower part of the Puddle Springs Arkose Member in that area. The writer believes that the rocks north of the Rattlesnake Range that are included in Rich's upper drab sequence of his lower finegrained facies are the basinward equivalent of at least the lower few hundred feet of the Puddle Springs Arkose Member, and also of part of Rich's upper coarsegrained facies. Rich's upper coarse-grained facies in the southeast corner of the basin is quite similar in lithology, age, and occurrence to the Puddle Springs Arkose Member in the area of this report.

North of the study area and west of the Dutton Basin anticline, the Wind River Formation has been almost entirely removed by erosion for a few miles. Farther north it dips gently northward into the basin. Thus, several miles north, strata equivalent to at least the lower part of the Puddle Springs Arkose Member should occur. Red-banded basal Wind River beds above the west bank of Muskrat Creek in the north half of T. 34 N., R. 91 W. may be equivalent to the lower finegrained member. Farther north, mostly drab beds comprise the formation. Murphy $(1956$, p. 11) and the writer have noted drab siltstone and claystone beds with interbedded coarse arkosic channel sandstones to the north and northwest close to the center of the basin; these sandstones are probably the stream-deposited basinward equivalents of some of the coarsest parts of the Puddle Springs Arkose Member. Still farther north, along the highway between Moneta and Shoshoni, conspicuous persistent channel sandstones near the axis of the basin are interbedded with drab greenishgray beds of silt and clay; the sandstones may have been largely derived from the north or west and deposited by the probably existent major eastward-flowing river of Wind River time (p. A42).

No detailed work has been done in the central part of the basin, between the area of this report and the Lysite and Lost Cabin areas. Sediments of the Wind River Formation in the Lysite and Lost Cabin areas were derived from the north or northwest. Correlation of parts of the formation between the two areas is highly uncertain and will have to await the discovery of diagnostic fossils in the south-central part of the basin. If the lithologic changes are the result of simultaneous diastrophism in the ancestral Owl Creek-Bighorn and Granite Mountains, the lower fine-grained member would be roughly equivalent to the upper part of the Lysite Member, and the Puddle Springs Arkose Member, to the Lost Cabin Member.

Red-banded beds of silt and clay with arkosic channel sandstones and a few granite conglomerate beds in the southwestern part of the Wind River Basin (Sinclair and Granger, 1911; Van Houten, 1950, 1954, 1955; Thompson and White, 1952b, p. 8) are equivalent to part of the Wind River Formation in the area of this report but are separated from it by ridges of pre-Tertiary rocks of the breached Conant Creek anticline. Although the formation has not been subdivided in the southwestern part of the basin, most of it is composed of finegrained green beds with numerous red bands typical of the lower fine-grained member. The distinctive unit one (Van Houten, 1955, p. 6) of the middle Eocene rocks (Wagon Bed Formation) conformably overlies the Wind River Formation in both areas and thus this relationship shows that the fine-grained variegated beds to the southwest are equivalent in age to the upper transition zone and to some of the Puddle Springs Arkose Member in the south-central part of the basin.

Lower Eocene deposits on the south side of the Sweetwater uplift are much thicker and coarser (Knight, 1937; Pipiringos, 1955; Masursky, 1962) than the Wind River Formation of this area. The Battle Spring Formation in the Red Desert area of the Great Divide Basin is a basin-margin coarse arkose more than 3,300 feet thick that intertongues with strata of earliest Eocene through middle Eocene age (Pipiringos, 1955, p. 103). The Wind River Formation in the area of the present report, therefore, is equivalent to part of the Battle Spring Formation. The Cathedral Bluffs Tongue of the Wasatch Formation and the Tipton Tongue of the Green River Formation in the Red Desert area are of latest early Eocene and earliest middle Eocene age (Masursky, 1962, table 1). The Puddle Springs Arkose Member is, therefore, equivalent to a part of the Battle Springs Formation, and the upper part of the member and the overlying upper transition zone are equivalent to parts of the Cathedral Bluffs Tongue of the Wasatch Formation and the Tipton Tongue of the Green River Formation.

\section{LITHOLOGIC UNITS}

\section{LOWIER FINE-GRAINED MEMBER}

The lower fine-grained member of the Wind River Formation consists predominantly of grayish-green siltstone, light-gray very fine to fine-grained quartzose sandstone, and olive- to grayish-green claystone. The 
member also includes some thin beds of grayish-red, red, or reddish-brown claystone and brown to black carbonaceous claystone or shale beds which locally contain dark-brown to black lignite or subbituminous coal. In parts of the area a thin discontinuous bed of conglomerate or gravel occurs at or very near the base of the formation. This is composed almost entirely of smooth rounded dark-brown to black chert pebbles $3 / 4-1$ inch in diameter from conglomerate in the Cloverly Formation and white siliceous shale chips from the Mowry Shale with a matrix of fine- to medium-grained white quartzose sand. There are a few thin beds of yellowish-gray coarse-grained arkosic sandstone in the upper part of the member.

The typical thickness of the fine-grained member is about 120 feet. The member is more than 150 feet thick locally south of the Dutton Basin anticline (pl. 3, D9). It thins to zero, however, southward and onto the ridges of resistant pre-Tertiary rocks such as the Mowry Shale and the Cloverly Formation, but it is present in some valleys between such ridges. It also disappears by overlap on the north flank of the Sweetwater uplift and on the high ridges forming the flanks of the breached Dutton Basin anticline to the east.

The entire thickness of this member is very well exposed on the lower part of the north-facing slope at Sarcophagus Butte (fig. $8 A$ ). Very fine-grained to fine-grained light-gray sandstone and siltstone with a few red bands of silty clay form the castellated erosion remnants known as the "Clay City Ruins" in the NW1/4 sec. 21 , T. 33 N., R. 90 W. Other excellent and complete exposures of this member occur in the $\mathrm{SW} 1 / 4$ sec. 18 and the NW1/4 sec. 19 (fig. $8 B$ ). Good exposures occur also in the west-central and southwestern parts of the Puddle Springs quadrangle and in the southeastern and northwestern parts of the Rongis Reservoir SE quadrangle. No attempt was made to delineate this member east of about the west fork of West Canyon Creek (secs. 19, 30, and 31, T. 33 N., R. 89 W.) because coarsegrained beds of the Puddle Springs Arkose Member occupy the normal position of this member along the Fremont-Natrona County line and because only little detailed drill-hole data showing the base of the formation farther east were available. Beds of this member probably occur in the subsurface along the west flank of the Rattlesnake Range.

Throughout most of the Puddle Springs quadrangle east of Muskrat Creek, and in the west-central, southwest, and south-central parts of the Gas Hills quadrangle, the relationsihp of the lower fine-grained member to the Puddle Springs Arkose Member is not very complex. Rocks characteristic of both members, however, are interbedded for perhaps a hundred feet above

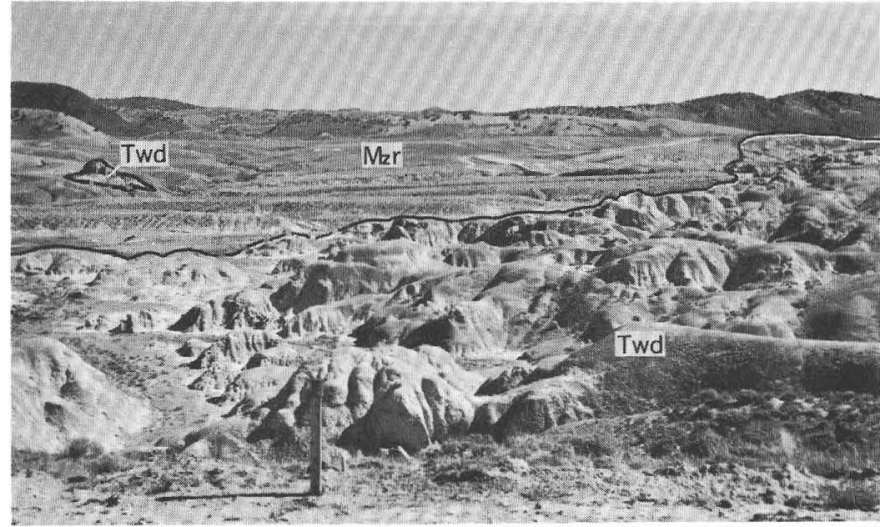

A.

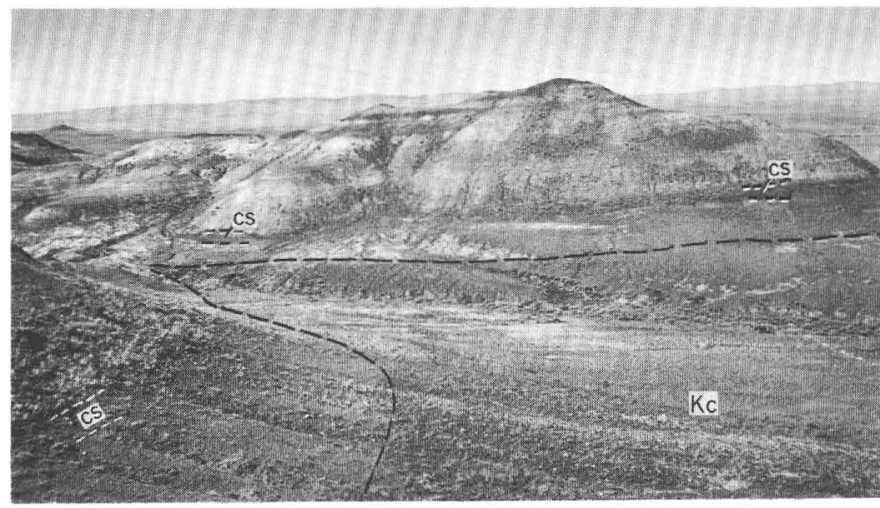

B

Figure 8.-Lower fine-grained member of the Wind River Formation. A. Characteristic hummocky badland weathering. Twd, Wind River Formation; Mzr, Mesozoic rocks. View southeast toward the west flank of the Dutton Basin anticline from NW1/4 sec. 22 , T. 33 N., R. 90 W. Photograph by H. D. Zeller. $B$. Beds northeast of Puddle Springs, view to the southwest. cs, carbonaceous shale near base; Kc, Cody Shale. Stratigraphic section $\mathrm{C} 1$ was measured on the opposite side of highest hill. SW1/4 sec. 18 , T. 33 N., R. 90 W.

the contact in some localities, particularly at Sarcophagus Butte and to the southeast. Moreover, west of Muskrat Creek in the Puddle Springs and the Rongis Reservoir SE quadrangles, the exposed beds may generally be classified as typical of the lower finegrained member or of the Puddle Springs Arkose Member, but the boundary between these members of the formation is uncertain because of the intricate interbedding. The contact, therefore, has been carried only to the west edge of the Puddle Springs quadrangle on geologic maps (Soister, 1966b, 1967b).

\section{CONGLOMERATE}

Some conglomerate and conglomeratic sandstone beds occur at or near the base of the lower fine-grained member where the Wind River overlies the Cody Shale 
in this area and younger Cretaceous rocks to the north. Most of this conglomerate occurs in the west half of the Puddle Springs quadrangle, but some is in the Rongis Reservoir SE quadrangle also. The conglomerate beds are highly lenticular and mostly semiconsolidated. Thickness is generally about 1-2 feet and probably does not exceed 15-20 feet.

Materials composing the conglomerate are quite uniform. The coarse particles consist of plates and chips of white siliceous shale from the Mowry Shale that are generally 1-3 inches, but as much as 10 inches, long; small rounded dark-brown to black chert pebbles from conglomerate in the Cloverly Formation; and subangular to subrounded pebbles, cobbles, or small boulders of brown to gray silicified fine- to medium-grained sandstone that is probably also from the Cloverly Formation. Dark-gray or brown silicified wood fragments, generally subrounded and pebble or small cobble size, occur in some localities. The matrix of the conglomerate, and the main constituent in the conglomeratic sandstones, is fine- to medium-grained well-rounded reworked quartz sand grains from the Cloverly and Morrison Formations and perhaps from sandstone in the Sundance Formation and Nugget Sandstone. Jarosite partly coats some of the materials. The general absence of granitic debris from the basal gravel of the Wind River Formation provides a good criterion for distinguishing it from nęarby Quaternary gravel which commonly contains some granite pebbles. Cobbles and subangular boulders of silicified Cloverly chert pebble conglomerate as much as 2 feet in diameter occur locally in the thick basal gravel.

An excellent exposure of conglomerate near the base of the formation forms the upper 8 feet of the side of the prospect pit near the center of the $\mathrm{E} 1 / 2 \mathrm{~W} 1 / 2$ sec. $3, \mathrm{~T}$. 33 N., R. 91 W. Sedimentary structures at this locality indicate deposition by a northward-flowing stream.

\section{SANDSTONE}

Along the north-facing slopes north and east of Sarcophagus Butte, in secs. 21 and 22 , T. 33 N., R. 90 W., the lower fine-grained member includes light-gray wellsorted quartzose sandstone which is mostly very fine to fine grained but partly medium grained. The sandstone is mainly semiconsolidated and is noncalcareous, but some of it forms small steep castlelike hillocks known as the "Clay City Ruins." Most of the sand is subrounded to rounded, is apparently reworked, and was mainly derived from sandstone in the Cloverly, Morrison, Sundance, and Nugget Formations, a very short distance to the east and southeast. In the northern part of sec. 22 , and a few feet to a few tens of feet above the Cody Shale, irregular lenses of this fine- grained sandstone, generally about 6 inches thick, are petroliferous. The sandstone and siltstone at the base of the formation contain jarosite and limonite.

In stratigraphic section A8 (pl. 2) just west of Muskrat Creek, the sandstone beds in the lower 13 feet of the Wind River Formation are yellowish gray to light gray, are well sorted, and contain rounded grains that are probably from the Cloverly, Morrison, Sundance, and Nugget Formations and that are similar to the sand matrix in the basal conglomerate of the formation in this area. Above the lower 13 feet at this locality, and also in stratigraphic section A7, the sandstone beds are more silty and are arkosic; they are dusky yellow to yellowish orange or green to olive, and they contain green chlorite(?) grains. Many of these sandstones may be called subgraywacke and others, arkose.

In two localities in the Rongis Reservoir SE quadrangle, small outcrops of sandstone unusual to the Wind River Formation were noted. In the NE1/4NE1/4 SE $1 / 4$ sec. 5, T. 33 N., R. 91 W., at an elevation of 6,020 feet, a fine-grained light-gray well-sorted sandstone with predominantly rounded quartz grains and common rounded black grains lies above the Cody Shale and below a coarse arkosic calcareous channel sandstone bed. It apparently dips about $2^{\circ} \mathrm{N}$., whereas the nearby Cody dips $24^{\circ} \mathrm{N}$. Two miles to the south, in the SW $1 / 4$ SW $1 / 4 \mathrm{NW}^{1 / 4}$ sec. 17 , T. 33 N., R. 91 W., at an elevation of 6,050 feet, a fine-grained well-sorted light-gray sandstone with sparse coarse black chert (?) grains lies horizontally or dips about $1^{\circ} \mathrm{S}$.; it overlies the Cody Shale and apparently was eroded before clay of the lower finegrained member of the Wind River Formation was deposited above it. These sandstones bear some resemblance to sandstone in the Fort Union Formation (Paleocene) of the Castle Gardens area, about 10 miles to the northeast, and, therefore, are tentatively mapped as Fort Union (?) (Soister, 1966b). They may, however, be Wind River because of the slight dip. The dark grains could have come mainly from sandstone in the Frontier Formation a few miles to the south.

\section{SILTSTONE}

Siltstone is the major rock type in the lower finegrained member of the Wind River Formation. In four stratigraphic sections, D1, C1, and A8-A7, it makes up 34 percent, 65 percent, and 41 percent, respectively, of the member. Only in the Sarcophagus Butte section (D1, 34 percent) is it exceeded by very fine to mediumgrained sandstone (42 percent).

Most siltstone beds are 1-7 feet thick; in the Sarcophagus Butte stratigraphic section (D1) there are two intervals, 43 and 30 feet thick, of sandstone and siltstone interbedded, but the thickest single siltstone bed is 
13 feet thick. The basal siltstone in the stratigraphic section northeast of Puddle Springs (C1) is 14 feet thick.

The beds of silt weather into fine or coarse blocky fragments. Much of the siltstone is sandy and clayey and is interbedded with sandstone and claystone. Some of it grades into very fine grained sandstone; it generally appears to be approximately the same in composition as these sandstones except perhaps for having greater amounts of chlorite (?) and other mica flakes.

The siltstone beds are mostly light greenish gray, light yellowish green, and pale olive to olive gray; a few near the base of the member are light gray like the adjacent sandstone beds. The measured section northeast of Puddle Springs (C1, pl. 3) has three reddishorange to reddish-brown beds that are clayey siltstone, whereas most red beds in the Wind River Formation in this area are claystone. Gypsum, found as small selenite crystals in a few siltstone beds, seems to be related to clay in the siltstone or to adjacent beds of claystone. Some siltstone beds are slightly limonitic, and in basal sediments of the formation limonite and jarosite are common.

\section{CLAYSTONE}

Claystone makes up less of the lower fine-grained member than the general appearance of the unit suggests, because as clay is washed down over lower outcrops of siltstone and sandstone, the lithology is masked. This process occurs very commonly along the slopes north and east of Sarcophagus Butte in the "Clay City Ruins." In stratigraphic sections D1, C1, and A8-A7, claystone makes up about 20 percent, 8 percent, and 17 percent, respectively, of the lower fine-grained member. The term "claystone" rather than "clay shale" is used because these beds weather into blocky fragments, some with conchoidal fractures. The clay is plastic when wet and may be montmorillonite because it forms puffy slopes on weathering.

The principal colors of claystones are olive, olive gray, and dusky yellow green. However, many red and reddish-brown clay beds, generally 1-3 feet thick, make conspicuous bands in the lower fine-grained member. These red claystones are finely mottled red and green, but the red masks the green on the outcrop. In the Rongis Reservoir SE quadrangle a few purple clay beds were noted. In the Muskrat gas field, in the NE1/4 SW1 $1 / 4$ sec. 4, T. 33 N., R. 92 W., about 100 feet of variegated beds of the lower fine-grained member over the Cody Shale includes grayish-red-purple claystone beds, together with reddish-brown, yellowish-green, and other colored beds.

The gypsum in the area, in the form of single or twinned crystals or aggregates of several crystals of selenite, is mostly in claystone, but some is in sandstone and siltstone beds adjacent to claystone. The largest selenite crystals noted occur in claystone that is overlain or underlain by sandstone, and the greater size of these crystals may be due to the higher permeability of the adjacent beds.

\section{CARBONACEOUS BEDS}

Carbonaceous beds are rather uncommon in outcrops over most of this area. They are described by the area in which they occur.

\section{west of Sarcophagus Butte}

In the Sarcophagus Butte stratigraphic section (D1, pl. 3) about $1 \frac{1}{2}$ feet of siltstone near the base of the formation contains a large amount of carbonaceous material. This material is present only in a small area because most of the bed was apparently removed by erosion immediately before deposition of the overlying sandstone. Near the base of the formation $13 / 4$ miles to the northwest, in the center of the $\mathrm{E} 1 / 2 \mathrm{E} 1 / 2$ sec. $18, T$. 33 N., R. 90 W., a bed of pale-brown claystone contains numerous fragments and lenses of dark-brown carbonaceous clay. These two beds appear to occupy the same stratigraphic horizon, but a definite correlation cannot be made. In the conglomeratic sediments at the base of the Wind River Formation in the center of the $\mathrm{N} 1 / 2 \mathrm{~S} 1 / 2$ sec. 17 , T. 33 N., R. 90 W., there is some sandy carbonaceous silt shale with leaf imprints.

At stratigraphic section $\mathrm{C} 1$ a carbonaceous unit $121 / 2$ feet thick lies 16 feet above the base of the formation and can be traced in a north-south direction for at least half a mile in the $\mathrm{SW}^{1} 1 / 4$ sec. 18 and the $\mathrm{NW}^{1 / 4}$ sec. $19, \mathrm{~T}$. $33 \mathrm{~N}$., R. $90 \mathrm{~W}$. The unit consists of 5 feet of paleto dark-brown carbonaceous to very carbonaceous clay, 1.5 feet of impure gypsiferous (selenite) jarositic black subbituminous coal with vitrain and fusain, and a top 6-foot-thick unit of pale-brown jarositic gypsiferous carbonaceous shale that has 2 inches of shiny black coal at the top. Part of this unit, perhaps the bottom 5 feet, may be correlative with the carbonaceous clay in sec. 18, T. 33 N., R. 90 W. No carbonaceous beds were cored in the Atomic Energy Commission's hole 1 (pl. 3, C2) in sec. 29, and thus the carbonaceous unit does not extend this far southeast.

In the area just south of Coyote Springs (fig. 9) a carbonaceous shale zone as much as 38 feet thick is indicated from the Defense Minerals Exploration Administration data on drill holes in secs. 22 and $23, \mathbf{T}$. 32 N., R. 91 W., and from the writer's examination of partial cores from a hole in sec. 24 . It apparently lies at about the top of the lower fine-grained member, although in one hole it is overlain by 106 feet of silt and clay; in other holes it is overlain by coarse sandstone or 

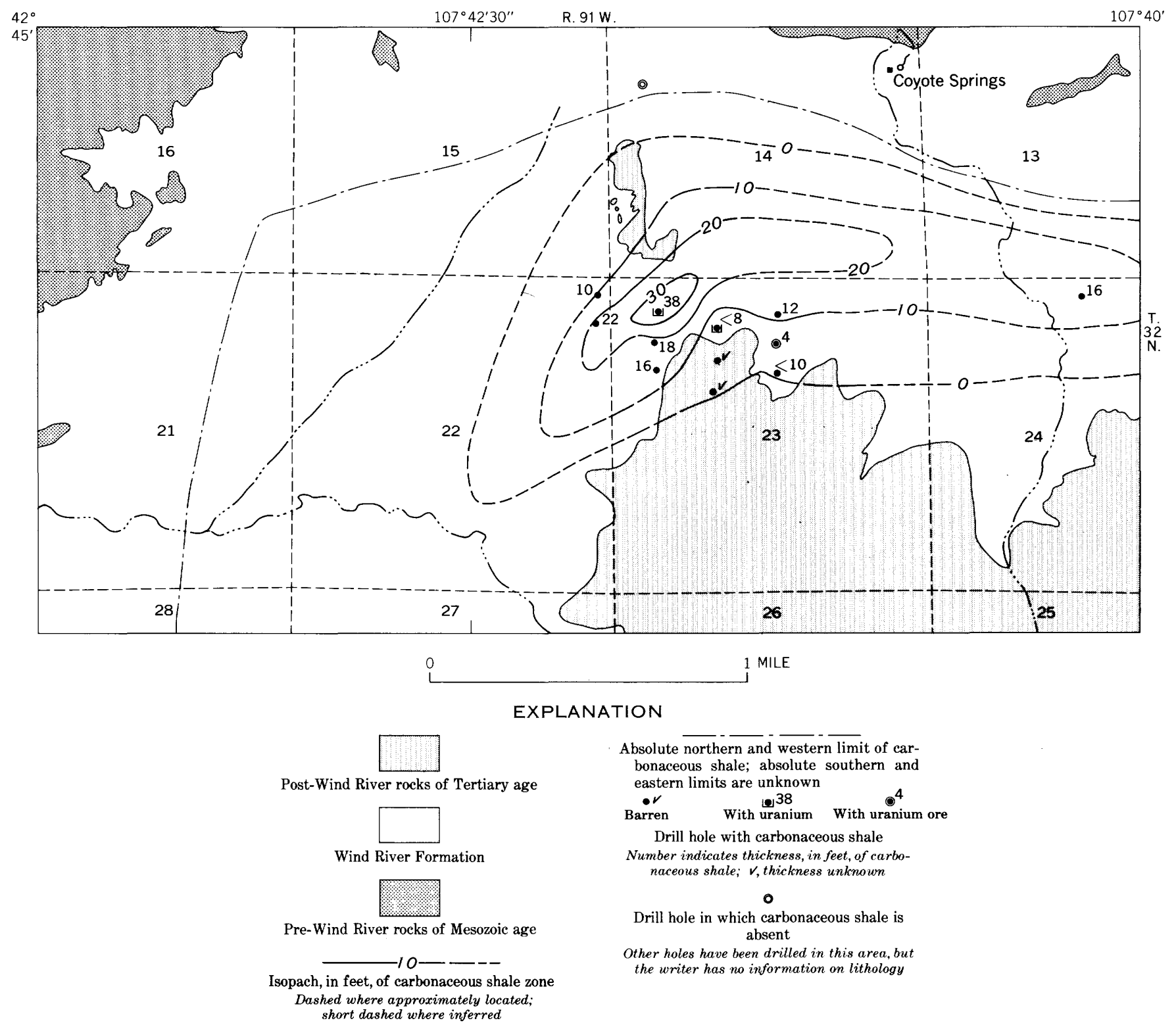

FIGURE 9.-Map of an area south of Coyote Springs showing variation in thickness of a carbonaceous shale penetrated by drill holes. Depth to the top of the shale ranges from 292 to 486 feet, whereas the variation in elevation of this top is only 65 feet.

conglomerate. Only fine-grained beds underlie it in the nine holes that penetrated the zone. In two holes a conglomerate bed 150 and 158 feet above the shale may be the Dry Coyote Conglomerate Bed. Another conglomerate 68 feet higher may be the Muskrat Conglomerate Bed. The abrupt thinning of the shale away from the hole in which it is of maximum thickness suggests that it may cover only a small area. Along with the rest of the Wind River Formation below the Dry Coyote and Muskrat Conglomerate Beds, it pinches out against ridges of the Mowry Shale to the north and the Cloverly Formation to the west. Data to the south and east are lacking, however, and the carbonaceous zone may be more extensive than indicated by the postulated zero isopach in figure 9.

Farther west, carbonaceous beds in the lower finegrained member are much less common and apparently are not persistent. In the $\mathrm{N}_{1} / 2 \mathrm{NW}^{1} / 4$ sec. 3, T. $32 \mathrm{~N}$., R. $91 \mathrm{~W}$., carbonaceous silt occurs near the base of the member. West of Muskrat Creek, in the $\mathrm{S} 1 / 2 \mathrm{NW}^{1} / 4$ NE1/4 sec. 21, T. 33 N., R. 91 W., a 1-2-foot-thick carbonaceous shale bed lies near the base in an area of finegrained rocks that were deposited in a swale in the Cody Shale.

In the Rongis Reservoir SE quadrangle, the formation is generally poorly exposed, and only a few thin 
carbonaceous beds, all of apparently limited extent, were noted. Thin carbonaceous shale beds of limited extent a few feet above the base of the formation were seen in the following localities: $\mathrm{N}_{1}^{1} / 2 \mathrm{NW}^{1 / 4} \mathrm{SE} 1 / 4$ sec. $5, \mathrm{E}_{1} / 2 \mathrm{SW} 1 / 4 \mathrm{SW} 1 / 4$ sec. 8 , and $\mathrm{NE} 1 / 4 \mathrm{SE} 1 / 4 \mathrm{NE}^{1 / 4}$ sec. 30 , T. 33 N., R. 91 W., and near the center of the NE1/4 NE $1 / 4$ sec. 25 , T. $33 \mathrm{~N} .$, R. 92 W. At the last locality, the carbonaceous shale is displaced about 4 feet by a small fault. No carbonaceous beds were seen in the well-exposed strata in the vicinity of the Muskrat gas field.

\section{Southeast of Sarcophagus Butte}

The most numerous outcroppings of carbonaceous beds in the formation occur on the northwest slopes of the hill on which the original uranium discovery was made in the Gas Hills district. Here, in stratigraphic section D2 (pl. 3), five carbonaceous beds totaling 7.8 feet in thickness in 50 feet of strata were measured. The contact of the lower fine-grained member and the Puddle Springs Arkose Member cannot be defined at this locality, but these carbonaceous beds are stratigraphically higher than at least the lower 100 feet of the Sarcophagus Butte section (D1, pl. 3). The strata in the vicinity of sections D1-D4 apparently include intertonguing beds of the lower fine-grained member and the Puddle Springs Arkose Member.

South of the hill just mentioned, in the NE $1 / 4 \mathrm{NE} 1 / 4$ NW1/4 sec. 26, T. 33 N., R. 90 W., a thick carbonaceous interval was exposed in May 1956 in a Lucky Mc openpit mine (D3, pl. 3; fig. 10). At this locality, the apparent dip on the carbonaceous beds of $6^{\circ}-7^{\circ} \mathrm{S}$. may be partly due to differential compaction of the Wind River Formation sediments on the flank of the Dutton Basin anticline. A coal bed 1.2 feet thick here is underlain by at least 2-3 feet of carbonaceous claystone and is overlain by about 1 foot of carbonaceous shale. A short distance south in the mine, the lower part of the interval was subbituminous coal, and the total carbonaceous interval was at least 6 feet thick (fig. 10). The coal is black and very crumbly, has layers of vitrain, and has jarosite along the bedding of the upper part. Jarosite is also present in the lower part of the carbonaceous shale overlying the coal.

In an area of several square miles extending southeast, south, and southwest from the Lucky Mc mines, almost every sufficiently deep drill hole of which the writer has knowledge penetrated a carbonaceous shale, claystone, and (or) a coal interval at the top of or a very few feet below the top of the lower fine-grained member. Because the only carbonaceous bed penetrated in most of these holes apparently occupies approximately the same stratigraphic horizon in all holes, the author believes that it is the same bed and that it corre- lates with the thick carbonaceous interval at the Lucky Mc No. 2 mine. It is present only in the central Gas Hills uranium district, and for convenience of reference, it is known as the central carbonaceous zone (Soister, 1966c, p. 45). By correlations between the Atomic Energy Commission's core holes 4 (C11, pl. 3) and 5 (D5, pl. 3), it is about 195 feet below the Dry Coyote Conglomerate Bed. The known area underlain by this carbonaceous interval is shown in figure 11.

\section{west of Rattlesnake Range}

In the area underlain by the East Canyon Conglomerate Bed (fig. 2, area F), the lower fine-grained member is not present, and no carbonaceous beds are known in the lower part of the Wind River Formation. East of the area of this conglomerate, however, carbonaceous beds occur in fine-grained strata stratigraphically higher than the lower fine-grained member. The formation here consists of interbedded fine- and coarse-grained beds. Numerous and (or) persistent carbonaceous beds probably occur in the lower fine-grained member between Black Mountain and the Rattlesnake Range but only in the subsurface.

\section{PUDDIE SPRINGS ARKOSE MEMBER}

\section{GENERAL DESCRIPTION AND OCCURRENCE}

The thick coarse arkosic uranium-bearing part of the Wind River Formation in the south-central part of the Wind River Basin was referred to as the "upper coarsegrained facies" in several previous reports (Zeller and others, 1956; Zeller, 1957; Soister, 1958). This arkosic facies has now been named the Puddle Spring Arkose Member (Soister, 1966c) from the best exposures east of and 1-4 miles south of Puddle Springs Ranch. No complete section of the member can be measured at the surface, but several drill holes, particularly the core holes of the Atomic Energy Commission, have penetrated it, as well as the rest of the formation (pls. 2,3,4). The composite sections and drill-hole logs of area $\mathrm{C}$ (fig. $2 ; \mathrm{pl} .3$ ), the type area, may be considered most typical of this member and, in fact, of the entire formation in the south-central part of the Wind River Basin; however, owing to the abrupt and drastic facies changes (fig. 7; pls. $2,3,4)$, no single stratigraphic section has been designated as the type section of the Puddle Springs Arkose Member.

Strata of this member are now confined principally to the area between the north edges of the Puddle Springs, Miles Ranch, and Ervay Basin quadrangles on the north, the Granite Mountains on the south, the Rattlesnake Range on the east, and the Conant Creek anticline on the west. The only substantial deposits probably assignable to the member outside the report 


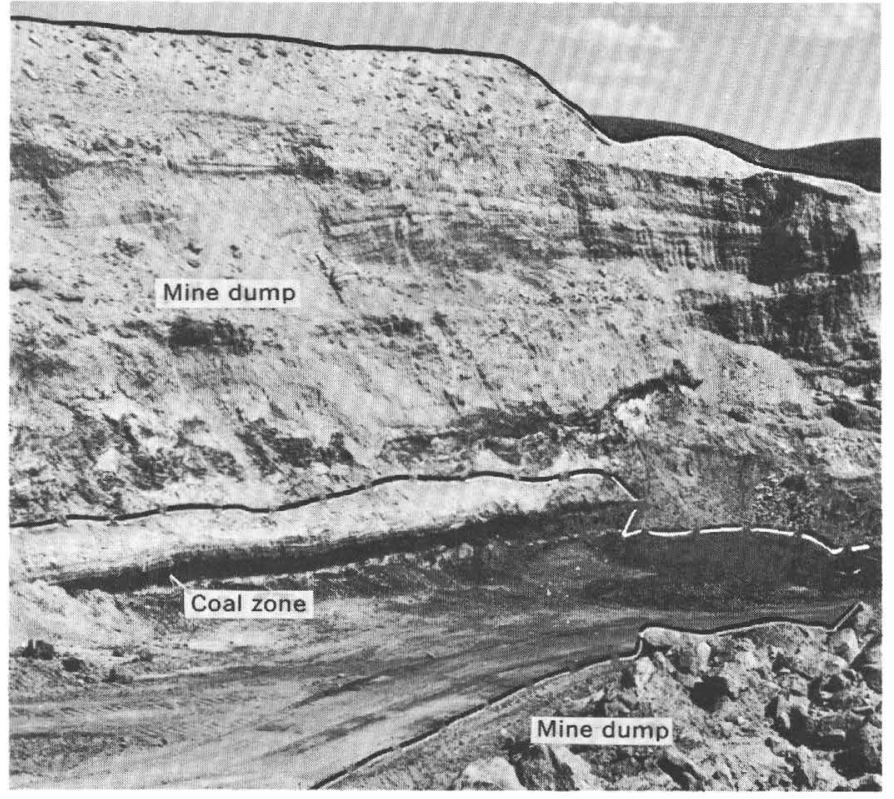

Figure 10.-Coal and carbonaceous shale of the central carbonaceous zone at the Lucky Mc No. 2 open-pit uranium mine. A. Distant view. B. Close view. Sec. 26, T. 32 N., R. 90 W. Photographs and samples by H. D. Zeller and R. G. Coleman, June 9, 1956.

$A$

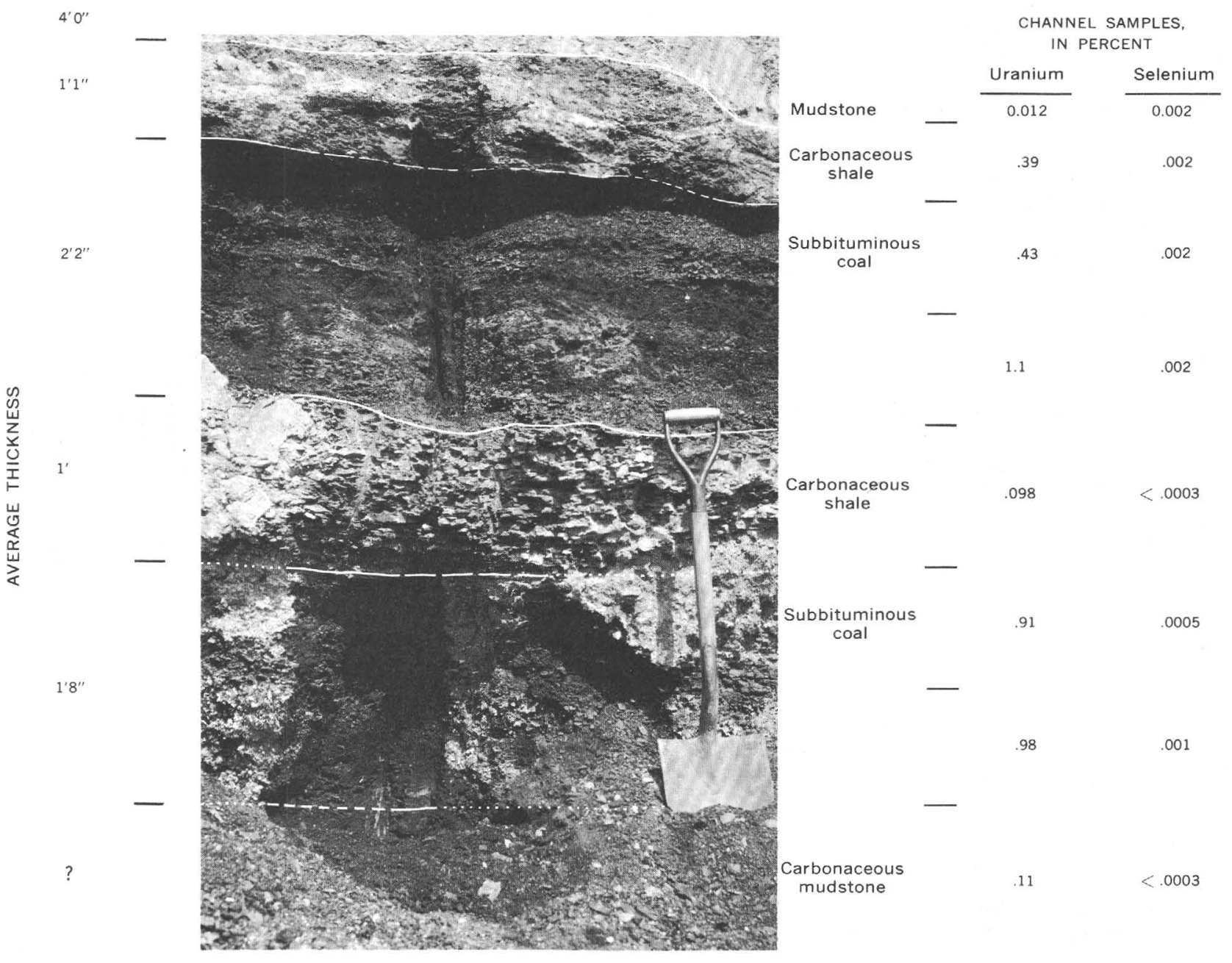




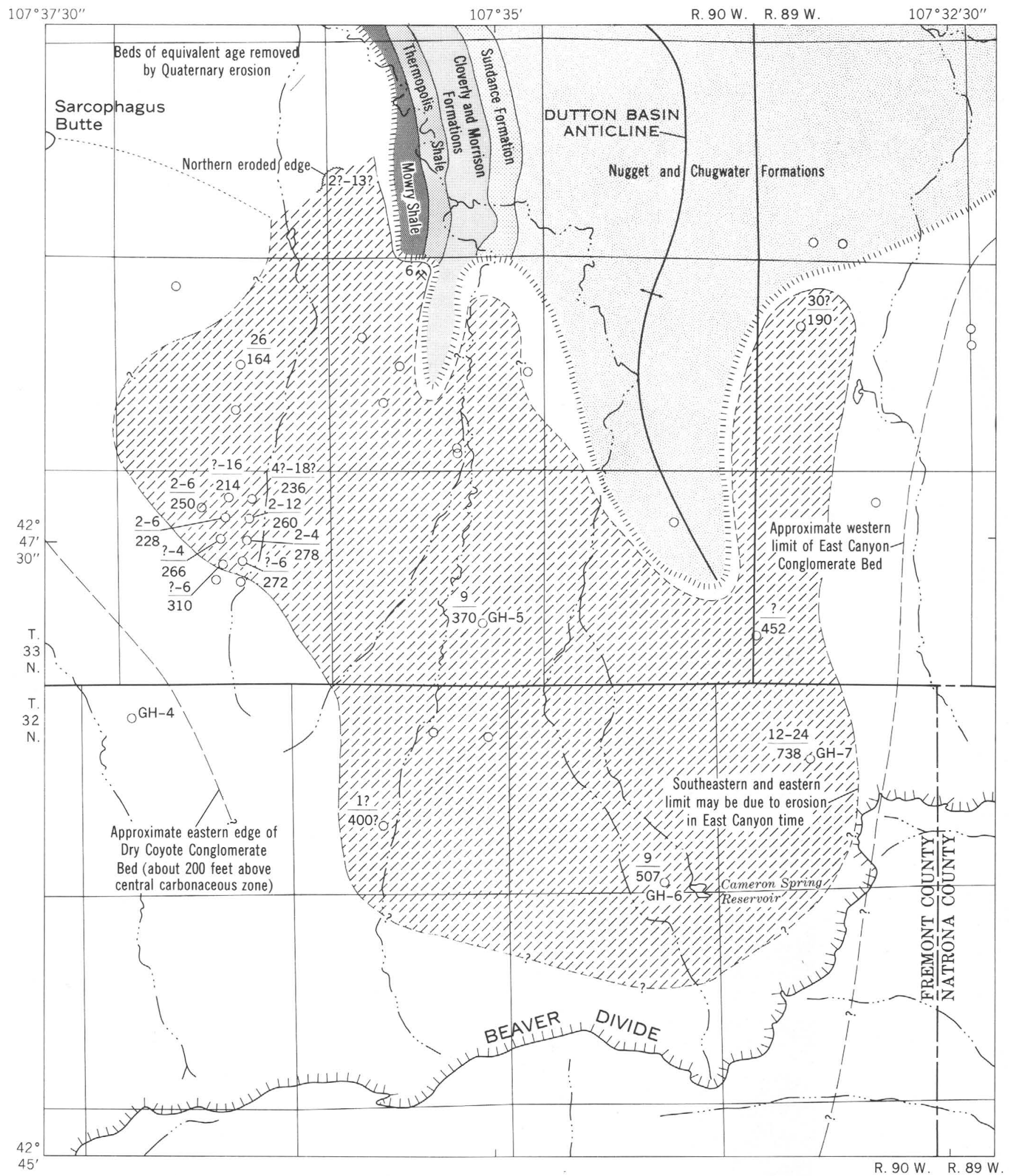

FIgURE 11.-Present extent of central carbonaceous zone of lower fine-grained member of Wind River Formation and approximate position and geology of highlands during its deposition. Names refer to present geographic features. 


\section{EXPLANATION}

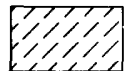

Area now underlain by central carbonaceous zone

Area in which the carbonaceous material was not deposited or was removed by erosion during Wind River time

Pre-Tertiary rocks outcropping during deposition of the carbonaceous material: Mowry, Thermopolis, Cloverly (Lower Cretaceous), Morrison, Sundance, Nugget (Jurassic), and Chugwater (Triassic) Formations

Boundary of carbonaceous zone

Solid where located within a few hundred feet; dashed where located possibly within a quarter of a mile; short dashed where uncertain; and queried where highly uncertain

Inferred contacts between pre-Tertiary formations during time of deposition of carbonaceous material

1111111111111111111111

Approximate border of highland area during deposition of carbonaceous material

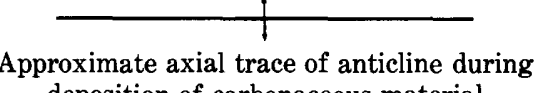

deposition of carbonaceous material

0

Drill hole used to determine presence or absence of carbonaceous material

GH, Atomic Energy Commission core hole

$$
\frac{12-24}{738}
$$

Main carbonaceous bed is 12 feet thick in 24-foot thick interval which contains carbonaceous beds

Depth to top of main carbonaceous bed is 738 feet

6 父

Open-pit mine exposing carbonaceous zone

Figure gives thickness of zone area are the coarse arkosic strata in the southeast corner of the Wind Basin (Rich, 1962).

The original thickness of this member was generally about 400-800 feet over much of the area. It thins, however, by overlap onto hills, ridges, and highlands of the buried pre-Wind River surface, and in much of the southern part of the report area it is absent (fig. 2). Some complete thicknesses in drill holes are shown on plates 3 and 4 .

The Puddle Spring Arkose Member consists primarily of massive very coarse grained to coarse-grained conglomeratic arkosic sandstone and granite granule to boulder conglomerate, with some fine- to mediumgrained feldspathic arkosic sandstone; beds of siltstone and claystone; and a few thin beds of carbonaceous shale, carbonaceous claystone, and carbonaceous siltstone. The arkose is sufficiently consolidated to allow almost vertical open-pit mine walls more than 100 feet high to stand at least a few years without slumping. It is soft enough, on the other hand, to allow removal by earth-moving machines without recourse to blasting except where concretionary masses are present. The arkose at and near the surface has been oxidized and is mainly yellowish gray to grayish yellow. Below the water table and in many places for several tens of feet above the water table, the arkose is unoxidized and is mainly green, greenish gray, blue, or bluish gray. Unoxidized arkose above the water table for some distance may be a result of recent regional lowering of the water table or of seasonal fluctuations.

Rock fragments in these beds consist principally of white granite, white feldspar cleavage fragments from the granite, massive light-gray to white quartz, and light-gray to brownish-gray quartzite. Locally, chips and plates of white siliceous shale from the Mowry Shale and $1 / 4^{-1}$-inch smooth, rounded black to brown chert pebbles from the Cloverly Formation make up most of the conglomerate. Coarse rock fragments, which vary in size and abundance laterally and vertically in the Puddle Springs Arkose Member, include (1) boulders and smaller particles of gneiss, gneissoid granite, pegmatitic granite, dark-gray chert, light-gray quartzite, white vein quartz, chlorite schist, quartzitic reddish-brown fine- to medium-grained sandstone; (2) cobbles and smaller particles of black chert, serpentine, banded quartzite, schistose to gneissic quartzite, dark-green to dark-gray mafic dike rocks, sparse white to lightyellowish-gray limestone; and (3) pebbles of green quartzite, white chert, and epidote.

Most beds in the Puddle Spring Arkose Member are so poorly consolidated that their structure is obscure. Many are 1-10 feet thick. Where exposed, nearly all of them appear to be massive bedded and generally 
flat bedded, although faint northward-dipping fluviatile crossbedding can be seen in a few places in the sandstone. A few of the hard calcareous sandstones are flat bedded, and at least some are crossbedded. Much of the bedding is regular and even, with only local small-scale channeling, but thin lenticular units are numerous. Only a few beds are traceable for more than a few hundred yards.

A few persistent coarse conglomerate beds are present. Of these the Dry Coyote and Muskrat Conglomerate Beds are sheetlike and regular bedded over a few square miles; the East Canyon Conglomerate Bed filled a long, narrow north-trending channel. Other minor conglomerate beds are of too limited extent to name. Much of the sandstone occurs in massive poorly to semiconsolidated beds several tens of feet thick, although thin beds are numerous. Siltstone and claystone beds in this member are generally less than 10 feet thick, and very few of them are fissile or thin bedded; therefore, the term "shale" is not applicable.

Cementing materials include clay, calcium carbonate, gypsum, goethite, limonite (field term used in report includes goethite), jarosite, pyrite, marcasite, black manganese oxides, and silica. Less common interstitial materials, mostly in the uranium deposits, include minerals of uranium, molybdenum, arsenic, and selenium, as well as opal and carbonate fluorapatite (R. G. Coleman, written commun., 1955). Also a very rare occurrence of hydrozircon in sec. 15, T. 35 N., R. 89 W., just north of the Ervay Basin quadrangle, was described by Coleman and Erd (1961) ; possibly, other local deposits of hydrozircon as a cement in arkose occur in this area, but none have been recognized. Most of these cementing materials are irregularly distributed and commonly concentrated in disorete beds or masses, particularly in association with uranium deposits.

In general, only a small amount of calcium carbonate is present as cement in some of the coarse arkosic sandstones, granule conglomerates, and siltstones of the Puddle Springs Arkose Member. Nevertheless, some calcite-cemented beds are scattered throughout the member in most parts of the area in contrast to the virtually noncalcareous lower fine-grained member and the upper transition zone of the Wind River Formation. Calcium carbonate cement occurs mainly in some lenticular to persistent, mostly thin arkosic sandstone beds, in a few irregularly and only locally cemented arkose beds (frontispiece), and in concretionary masses commonly a few inches in diameter to about 2-10 feet long by 1-2 feet wide. The calcareous sandstones are described in the section "Channel sandstone beds."

Spherical to log-like calcium carbonate-cemented concretions, though not common, have been found in various localities in the Puddle Springs Arkose Member. Most are in very coarse grained conglomeratic arkosic sandstone, but a few are in siltstone. Many have rims of limonite that probably resulted from the oxidation of pyrite or marcasite. A few have rims of manganese oxide, and in the area of uranium deposits, uranium minerals are associated. Concretions are most prevalent at the base of coarse-grained sandstone overlying siltstone or claystone, but some are scattered throughout the sandstone beds. In an excellent exposure cut by a bulldozer at section B3 (pl. 2), limonite- and manganese oxide-rimmed concretions occur at the very top of a sandstone bed overlain by siltstone. In the same exposure, several concretions occur in sandstone near a normal fault, and one concretion adjacent to it appears to have been partly crushed by movement on the fault.

Pyrite and marcasite occur in some of these concretions, and locally they form the principal cementing material. At and near the ground surface most pyrite and marcasite have been oxidized, and these minerals are probably the source of most of the goethite and limonite in beds of the member.

Interstitial limonite occurs (1) in spherical, lenticular, or irregular forms, (2) as rims around calcareous sandstone concretions and around large rock fragments in sandstone and conglomerate, (3) as rims commonly about 1 inch thick at the base of some sandstones, (4) as laminae along or across the bedding in sandstones, (5) interstitially throughout some sandstone and conglomerate beds locally, and (6) along joints and faults in claystone, siltstone, and sandstone. The distribution of most of the limonite indicates that it was formed after the normal faulting and southward tilting in this area. In some places, the spherical, lenticular, or irregular limonitic spots in sandstone have cores of interstitial brownish-gray material that may be carbonate fluorapatite. In other places, limonite, as well as the prevalent pale-yellow coloring matter, has been partly removed by leaching, a process producing white bleached spots; this bleaching is common within an inch or so of black or brown carbonized wood in sandstone. In one locality, a relatively large area of bleaching cuts across bedding, but the reason for this is not apparent; in this bleached sandstone the uranium content is lower than in the adjacent limonitic sandstone and, therefore, the uranium as well as iron oxide has been removed by leaching.

Jarosite is similar in occurrence to limonite, but it is less common and occurs mostly as interstitial material rather than rims around concretions. Abundant jarosite was noted in about 40 feet of coarse arkosic sandstone below the Dry Coyote Conglomerate Bed at the 
Hope (formerly Upetco) mine near the center of the S1/2SE1/4 sec. 1, T. 32 N., R. 91 W.

In a few places, irregular patches of noncalcareous sandstone are tightly cemented by silica and (or) carbonate fluorapatite, commonly with intermixed limonite or jarosite. In the Phil 3 mine, coarse conglomeratic arkosic sandstone exposed on a vertical face had a flat 6 -inch-thick uraniferous layer cemented probably by carbonate fluorapatite with a 2 -inch-thick limonitic layer above and below and a 1-inch-thick layer of black manganese oxide between the top limonitic layer and the carbonate fluorapatite (fig. 12).

Gypsum occurs mainly as single and twinned selenite crystals as much as 3 inches long or as aggregates of crystals in claystone, siltstone, clayey sandstone, or carbonaceous beds. Some powdery white gypsum occurs in veinlets or tiny shrinkage cracks in these beds or along fractures. In a prospect pit a few feet below the Dry Coyote Conglomerate Bed at the west line of the NW1/4SW1/4SE1/4 sec. 10, T. 32 N., R. 91 W., several concretions occur in siltstone. These concretions are spheri- cal to dumbbell shaped, about 1-6 feet long, and consist of rosettes and other aggregates of selenite crystals generally 1-2 inches long in a matrix of silt. Gypsum apparently occurs mainly in the oxidized zone except perhaps in the lower part of the formation where it overlies the Chugwater Formation. R. G. Coleman (written commun., 1955) stated that seams of gypsum occur in the dark unoxidized uranium ores. These uranium deposits, however, are near the oxidized zone, or they are isolated unoxidized pods surrounded by oxidized rocks. In the $\mathrm{SE}_{1} 1 / 4 \mathrm{NW}^{1 / 4} \mathrm{SW}^{1} / 4$ sec. 32 , T. $33 \mathrm{~N}$., R. $90 \mathrm{~W}$, at an occurrence of yellow uranium minerals in the oxidized zone, black carbonized wood was found in which selenite partly replaced the cell walls.

White powdery caliche $\left(\mathrm{CaCO}_{3}\right)$ of very recent origin is common in joints of this member, as well as at the base of, and in, soil zones overlying the member. Some yellow uranium minerals also occur in joints and at the base of the soil zone in certain localities, particularly in the Bullrush and Sagebrush areas, and in these occurrences probably have an origin similar to that of caliche.
U, IN PERCENT

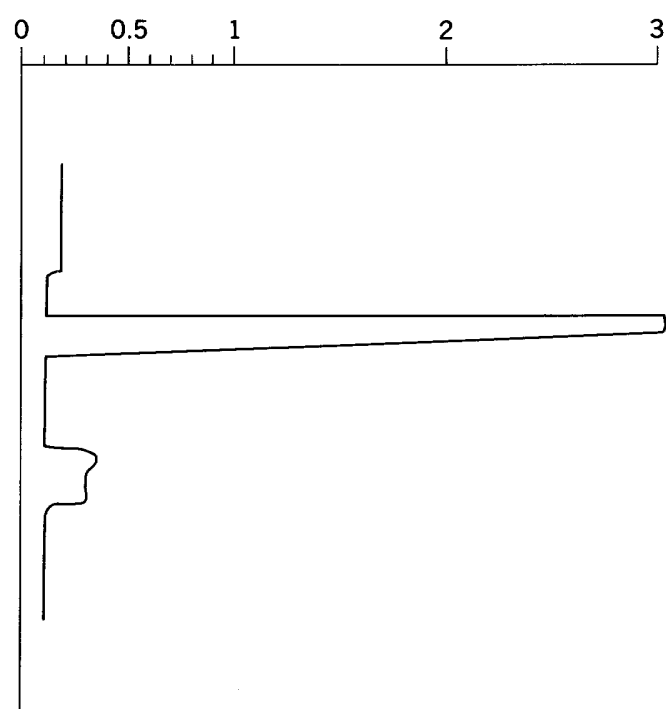

$\mathrm{Mn}$, IN PERCENT

Fe, IN PERCENT

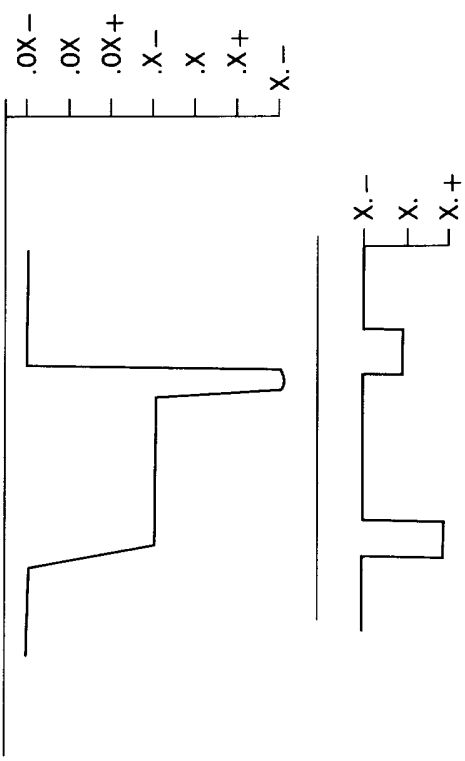

FIGURE 12.-Diagrammatic section of flat, tabular body containing limonite, manganese, and uranium in arkosic very coarse grained conglomeratic sandstone immediately above Dry Coyote Conglomerate Bed; vertical face at Phil 3 mine, SW $1 / 4$ SW $1 / 4 \mathrm{SE}^{1 / 4}$ sec 1, T. 32 N., R. 91 W. Deposit was uniform over total exposed distance of about 30 feet. U, chemical analysis by C. G. Angelo, M. T. Finch, and J. S. Wahlberg; Mn and Fe, semiquantitative spectrographic analyses by J. C. Hamilton. 1. Typical yellowish gray very slightly conglomeratic sandstone; has scattered yellow uranium minerals interstitially and coating pebbles and granules. 2. Very limonitic, reddish-brown sandstone; has scattered metaautunite(?). 3. Manganiferous, black sandstone; has abundant yellow uranium minerals; one unknown yellow uranium mineral has very good X-ray pattern ( $d$ spacing of $6.8 \mathrm{~S}, 3.5 \mathrm{MS}$, and $3.3 \mathrm{MS}$ ). 4 . Core of tabular body, light olive-gray $(5 Y 6 / 1)$, probably contains carbonate fluorapatite; at base, layer of white powdery gypsum about one-fifth inch thick is overlain by very thin layer of yellow uranium minerals. 


\section{ROCK TYPES AND UNITS}

CHANNEL SANDSTONE BEDS

Hard calcareous coarse-grained arkosic sandstone beds, in general only about $2-5$ feet thick, are considered to mark the base of the Puddle Springs Arkose Member in the Puddle Springs quadrangle. Commonly, however, many such sandstone beds occur at a given locality, some at the base and within the member and some in the underlying fine-grained member.

Although such sandstones may be narrow in a generally east-west direction most of them appear to be fairly persistent in the north-south direction; they were clearly deposited in minor northward-flowing streams. The sandstone beds are generally overlain and underlain by finer grained rocks, but locally, by coarser grained rocks. These characteristics best differentiate this sandstone from the main mass of arkose of the Wind River Formation.

The channel sandstone beds are generally interbedded with green and red variegated claystone and siltstone and are most numerous in the western part of the Puddle Springs quadrangle and the southeastern part of the Rongis Reservoir SE quadrangle. Remnants of such sandstone beds form the cap on hills and buttes that stand as much as 100 feet above the general landscape.

At the base of stratigraphic section A7 (pl.2), a hard calcareous coarse-grained arkosic sandstone bed 3.3 feet thick contains abundant green chlorite(?) flakes and has tabular crossbedding that dips $21^{\circ} \mathrm{N} .45^{\circ}-80^{\circ} \mathrm{E}$. Other sandstones with similar lithology and occurrence, some possibly equivalent to this bed, occur in secs. 5,6 , 7, and 8, T. 32 N., R. 91 W., and also east of Muskrat Creek in secs. 2 and 3, T. 32 N., R. 91 W., secs. 34 and 35 , T. 33 N., R. 91 W., and in some other localities.

The most prominent channel sandstones are hard calcareous beds as much as 30 feet thick in the western part of the Puddle Springs quadrangle. East of Muskrat Creek, in the central part of the E1/2 sec. 4 and in the $\mathrm{SW} 1 / 4 \mathrm{NW} 1 / 4$ sec. 3 , T. 32 N., R. 91 W., relatively thick coarse arkosic calcareous sandstone lies at the base of the Wind River Formation. About 2 miles northnorthwest, in secs. 21 and 28 , T. 33 N., R. 91 W., the most conspicuous channel sandstone occurs. It overlies the Cody Shale in most of the area and beds of the lower fine-grained member in the $\mathrm{NE} 1 / 4$ sec. 21 ; it caps a prominent ridge. The hard arkosic sandstone is coarse to very coarse grained, contains abundant dark mica flakes (biotite and (or) chlorite), and has an orange cement that is probably calcite with finely divided limonite. This orange cement is very common in the channel sandstones in this part of the area, and was also noted in very similar sandstone beds northwest and north of the Rattlesnake Range.

A similar sandstone, possibly equivalent to that in secs. 21 and 28 , occurs farther north on the ridges in secs. 4 and 9, T. 33 N., R. 91 W., and undoubtedly farther north in areas not examined. A somewhat similar channel sandstone bed was noted during reconnaissance in the $\mathrm{S} 1 / 2$ sec. 34 , T. 36 N., R. 93 W., 19 miles northwest of the prominent bed west of Muskrat Creek and near the center of the Wind River Basin.

Few calcareous channel sandstone beds occur in the area between Puddle Springs Ranch and Coyote Springs on the west and East Canyon Creek on the east, except for those at or near the base of the Puddle Springs Arkose Member. The member here is coarser, thicker, and includes fewer fine-grained beds than in any other part of the report area.

In the $\mathrm{E} 1 / 2 \mathrm{~W} 1 / 2$ sec. 6 , T. 32 N., R. 90 W., calcitecemented arkose forms a conspicuous ledge about 35 feet above the Dry Coyote Conglomerate Bed (frontispiece and stratigraphic section $\mathrm{C} 7, \mathrm{pl}$. 3). This sandstone is different from the channel sandstone, however, for it is only a locally cemented zone in a thick mass of arkosic sandstone; the cementation is irregular and in some places cuts across bedding in the sandstone.

A highly calcareous interval, a short distance above the East Canyon Conglomerate Bed in secs. 4 and 9, T. $33 \mathrm{~N} .$, R. $89 \mathrm{~W}$. is mainly granite granule conglomerate to very coarse-grained conglomeratic arkosic sandstone (top of stratigraphic section F2). This interval probably is the equivalent of one or more persistent channel sandstone beds farther north in the Ervay Basin quadrangle and other areas toward the central part of the Wind River Basin. H. D. Zeller (oral commun., 1959) observed persistent channel sandstone beds in and north of the Ervay Basin quadrangle. One of these is in the $\mathrm{S} 1 / 2 \mathrm{~S} 1 / 2$ sec. 22 , T. 35 N., R. 89 W.; remnants of possibly the same bed in the $\mathrm{SE} 1 / 4$ sec. 15 contain some carbonate fluorapatite as cement.

The persistent channel sandstones are similar to the sandstone interbedded with siltstone and claystone found throughout most of the Wind River Basin. Thus, they may be thought of as normal deposits of the Wind River Formation, whereas the thick coarse arkose of the Puddle Springs Arkose Member is a more local facies of the formation.

LANDSLIDE DEBRIS FROM THE MOWRY SHALE

In the northwest corner of the Coyote Springs quadrangle and the northeast corner of the Muskrat Basin quadrangle, in secs. 16,20 , and 21 , T. 32 N., R. 91 W., 
large amounts of rubble and segments of beds from the hard siliceous Mowry Shale underlie and are interbedded with the Wind River Formation where the Wind River overlies the soft Thermopolis Shale (figs. $34,14)$. These deposits were shown as "slump" by Thompson and White (1952a) and as "Quaternary landslide deposits" by Van Houten and Weitz (1956) and by Zeller, Soister, and Hyden (1956). This writer's work, however, indicates that these are landslide deposits emplaced during Wind River time.

The debris from the Mowry Shale ranges from small fragments mixed with clay, silt, and sand of the Wind River Formation to large intact parts of beds at least 60 feet long (fig. 14D). Individual beds at least $2-5$ feet thick are distinguishable in some of the blocks. From a distance, the color of this material ranges from the silvery gray characteristic of Mowry Shale outcrops to a more prevalent moderate orange pink to pale yellowish orange with some moderate reddish orange to moderate reddish brown. These colors contrast with those of the Wind River beds, most of which appear grayish yellow to light greenish gray, and with the color of the Thermopolis Shale, which is brownish gray to black. Most of the pink to orange coloration in the landslide debris is due to intermixed reddish clay and silt. Many individual chips of the Mowry Shale are partly or completely discolored, possibly by a very thin coating of reddish iron oxide or ferruginous clay.

This landslide material extends from the present outcrop of the Mowry Shale southward for 2,200 feet. Each block or pile of landslide material is surrounded by the Thermopolis Shale alone, or by the Thermopolis and either the Mowry Shale or the Wind River Formation (fig. 13). The dip of the undeformed beds in the Thermopolis and Mowry Formations ranges from about $6^{\circ}-13^{\circ}$ N., and the strike is about N. $60^{\circ}-90^{\circ} \mathrm{E}$. The normal Wind River beds dip generally $1^{\circ}-3^{\circ} \mathrm{S}$. In contrast, the dip of bedding in the landslide blocks from the Mowry Shale is varied and generally steep. In the eastern part, the beds generally dip about $25^{\circ}-$ $65^{\circ} \mathrm{N}$. and strike about N. $30^{\circ}-50^{\circ} \mathrm{E}$. In the western part of the area east of Muskrat Creek, where much of the bedding is contorted, the dips noted were $20^{\circ}-$ $80^{\circ} \mathrm{SE}$., and the predominant strike ranged from due north to N. $40^{\circ}$ E. This structure indicates a counterclockwise rotation of the landslide blocks that generally increases with distance from the present ridge of Mowry Shale.

Relations between normal beds of the Wind River Formation and the landslide blocks are mostly obscure because the bulk of the soft sedimentary rocks of the normal beds have been removed by erosion around the landslide debris. Most of the blocks rest on the Thermopolis Shale, but a few small ones rest on normal beds of the Wind River Formation. In the northern part of secs. 20 and 21, small fragments of Mowry Shale occur in the basal beds of the Wind River Formation and are mixed with reddish-brown silt and clay. The large slump block near the south-central part of the area of figure 13 consists of contorted and southeast-dipping beds of Mowry Shale with intermixed reddish clay of the Wind River Formation. In the large slump block that straddles the main gully near the center of the $S^{1 / 2} S^{1 / 2}$ sec. 16 , the beds and debris from the Mowry Shale contain intermixed reddish-brown clay similar to that found in the Wind River Formation elsewhere. Grayish-green siltstone, claystone, and sandstone typical of the Wind River Formation lap onto the southeast side of this slump block (fig. $14 C^{\prime}$ ).

The isolated occurrence of landslide debris of the Mowry Shale west of Muskrat Creek, in the center of the $\mathrm{E} 1 / 2 \mathrm{NW} 1 / 1$ sec. 20 , is at approximately the same elevation, 6,400 feet, as occurrences to the east. It lies just in front of and immediately below the base of the Wind River Formation on the high hill to the southwest. Bedding in the shale here is highly contorted and broken. Although no more than 100 feet in diameter, this debris is conspicuous from a distance because of its deeper reddish color. The shale has a baked appearance and is moderate reddish brown with some pale-red-purple coloration on fresh surfaces. Disseminated hard lightolive-gray nodules of siderite (?) about 1-5 $\mathrm{mm}$ in diameter are in the shale, and apparently the same material fills fractures in it. The siderite (?) nodules and fissurefilling material may be due to local reducing conditions in Wind River time, and the red coloration to subsequent oxidation.

The landslide deposits apparently occur stratigraphically at or a short distance below the Dry Coyote Conglomerate Bed. At the time of deposition of these strata, the Mowry Shale and the Cloverly Formation held up ridges north and south, respectively, of a valley formed in the soft Thermopolis Shale in which some fine-grained rocks of the Wind River Formation were being deposited. As interpreted from conglomeratic deposits north of the ridge of Mowry Shale, the Mowry was being actively eroded off this ridge at the same time that very coarse grained arkosic materials from the ancestral Granite Mountains were being deposited in the area. From the concurrence of deposition of coarse detritus from the Mowry Shale and the very coarse grained granitic debris, the writer concludes that there was renewed elevation of the Sweetwater uplift, including this north flank, at this time. Precambrian granite of the present Granite Mountains now crops out only 7 

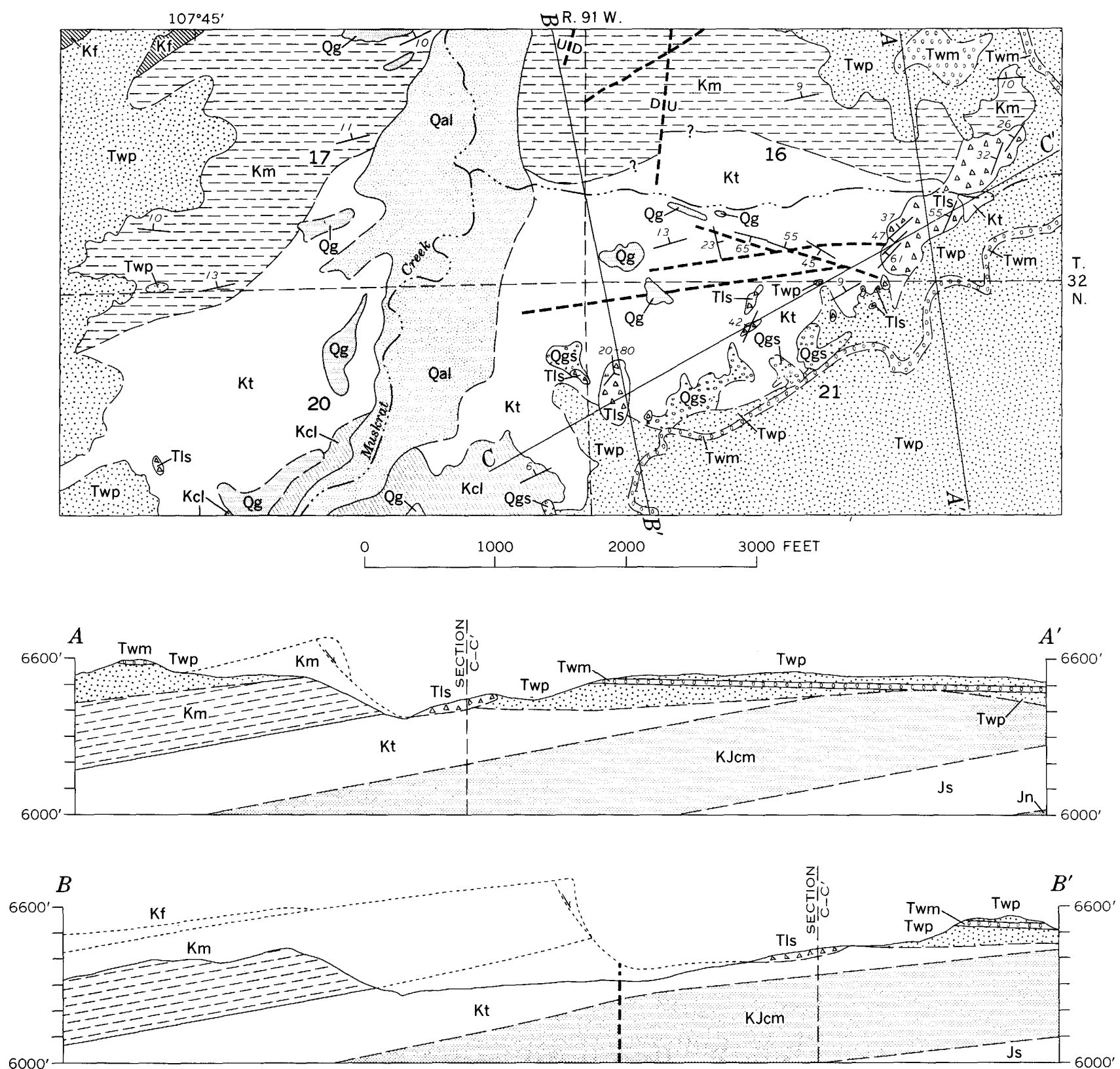


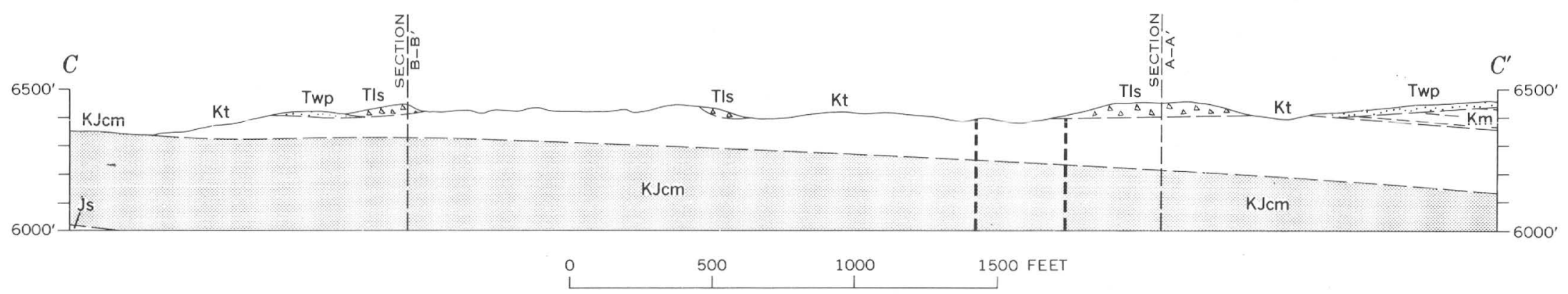

FIGURE 13.-Geologic map and cross sections showing lower Eocene landslide debris from the Mowry Shale west of Coyote Springs. 


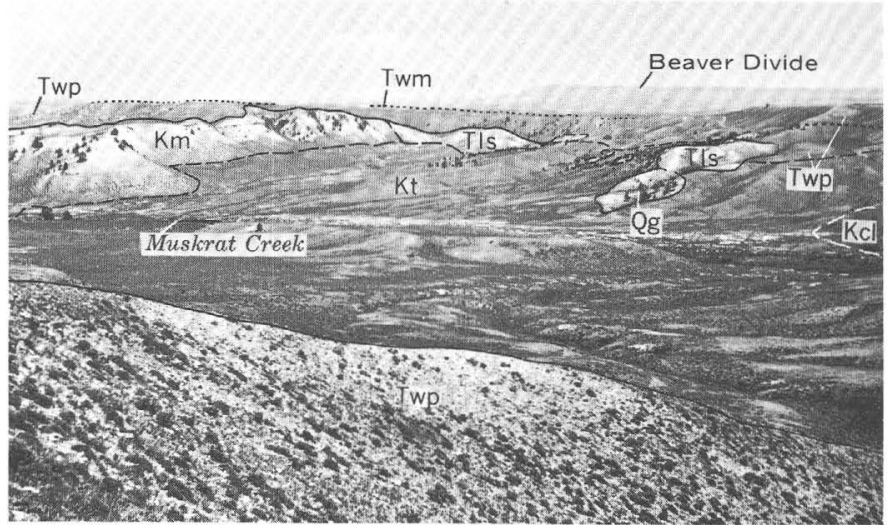

A

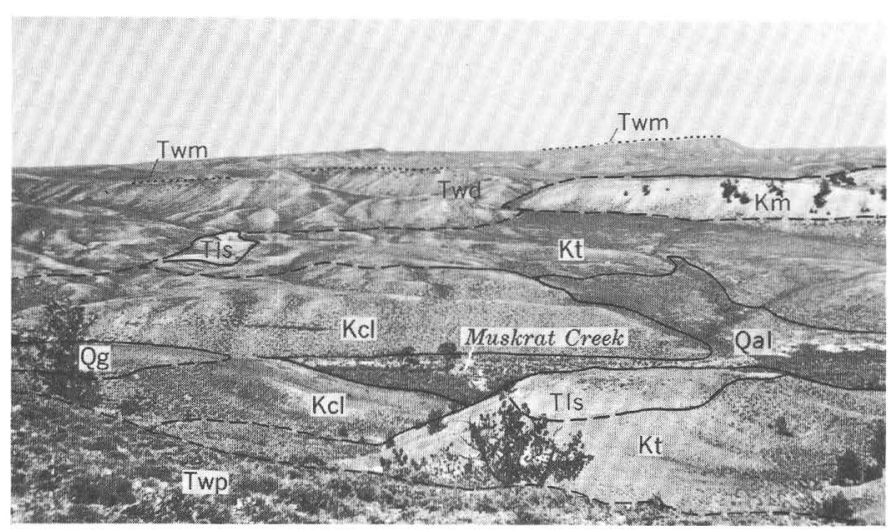

$B$

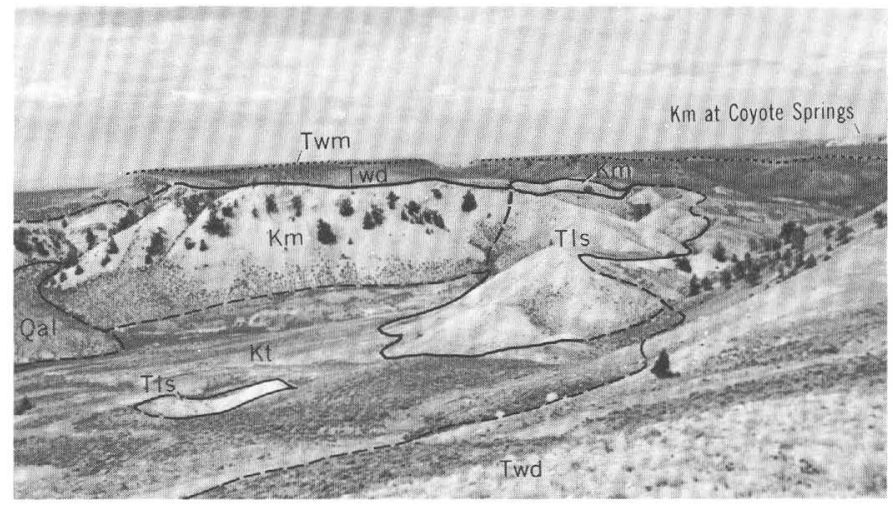

C

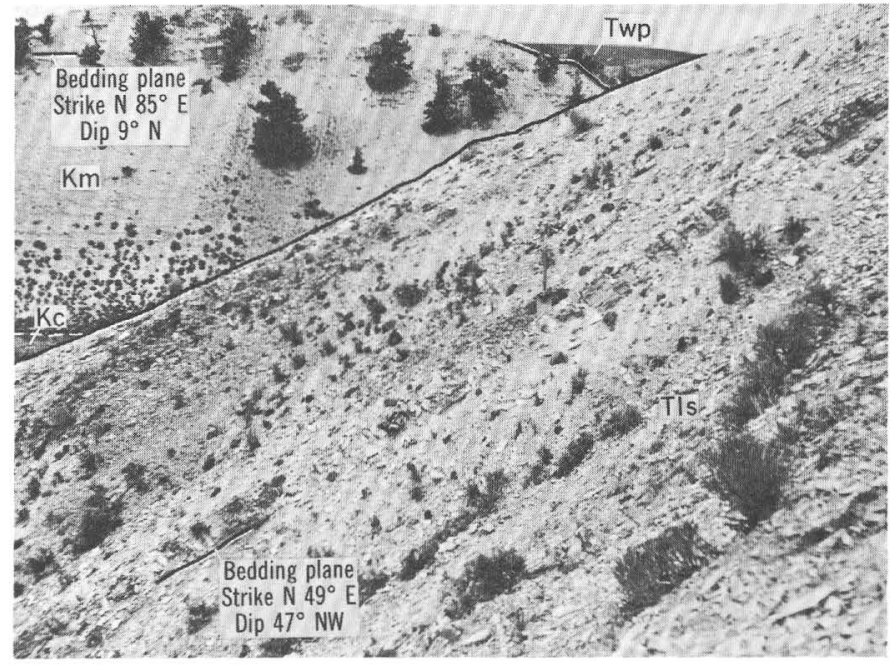

$D$

FIGURE 14.-Valley containing lower Eocene landslide debris (TIs) from the Mowry Shale. Mesozoic rocks dip $6^{\circ}-13^{\circ} \mathrm{N}^{\circ}$ and the Wind River Formation dips $1^{\circ}-3^{\circ}$ S. $A$. View east from NW $1 / 4$ sec. 20 , T. 32 N., R. 91 W. $B$. View N. $60^{\circ}$ W. from $\mathrm{SW}_{1 / 4} \mathrm{NW} 1 / 4$ sec. 21. $C$. View N. $35^{\circ}$ E. from NE1/4 NW1/4 sec. 21. D. Close view near central part of $C$; note intact beds of Mowry Shale in the landslide mass, from upper right to lower left corner, and 28-inch shovel near center for scale. Qal, Quaternary alluvium; Qg, Quaternary terrace gravels; Twm, Muskrat Conglomerate Bed; Twp, Puddle Springs Arkose Member; Twd, Wind River Formation, undifferentiated; Km, Mowry Shale; Kt, Thermopolis Shale; Kcl, Cloverly Formation.

miles south of this landslide area. During this elevation of the Sweetwater uplift, oversteepening caused by more rapid erosion of the Thermopolis Shale and (or) earthquake tremors attending the tectonic activity caused beds of Mowry Shale on top of the ridge to break off and to slide rapidly southward onto the Thermopolis Shale and locally onto beds of the Wind River Formation which were just being deposited in this valley.

About 3 miles to the east, near the center of the N1/2N1/2 sec. 13, T. 32 N., R. 91 W. (Soister, 1967b), an inlier of Mowry Shale which forms a hillock surrounded by Wind River rocks may be a lower Eocene landslide block that was later upfaulted during the postMiocene period of southward tilting and faulting. Criteria that indicate this may be a landslide block are the pinkish to orange color and the occurrence of finegrained Wind River rocks at the west foot of and perhaps below the hillock of Mowry Shale. The shale itself is roughly domal, and the beds dip outward from the center of the inlier. If this is a landslide block, it probably originated at about the same time and in the same manner as the definite landslide deposits just described.

CARBONACEOUS BEDS AND CARBONIZED AND SILICIFIED WOOD

Only a few carbonaceous beds occur in the Puddle Springs Arkose Member; these are described by the area in which they occur.

West of Muskrat Creek

In the Rongis Reservoir SE and Muskrat Basin quadrangles, the westernmost part of the report area, 
very little carbonaceous material or silicified wood was noted in the beds equivalent to the Puddle Springs Arkose Member, although this may be due to poor exposures. In the measured stratigraphic sections, carbonaceous material was found only in A5; here, about 88 feet stratigraphically below the Dry Coyote(?) Conglomerate Bed, a 0.9-foot-thick bed of grayish-brown carbonaceous silt shale lies in a conglomeratic arkose. About 0.4 mile to the east and at about the same stratigraphic level, some reworked brown carbonaceous material was found in a channel deposit containing conglomeratic sediments and siltstone.

\section{Muskrat Creek to Willow Springs Draw}

Carbonaceous beds and carbonized and silicified wood are common in this area (pls. 2, 3). Of 13 measured stratigraphic sections and drill-hole logs, only 3 had no carbonaceous material. The greatest amount of carbonaceous material and petrified wood on the outcrop lies immediately above to a few feet above the Dry Coyote Conglomerate Bed. Carbonaceous shale and carbonaceous siltstone more than 2 feet thick occur a few feet above this bed in the NE1/4 NW1/4 sec. 6, T. 32 N., R. 90 $\mathrm{W}$.; farther southwest in sec. 6 this carbonaceous interval is a pale-brown laminated siltstone a few feet thick.

A carbonized log at least 8 inches in diameter largely replaced by uranium minerals was found by miners, in July 1955, at the Globe Mining Co. Phil 4 claim, in the SE $1 / 4$ SE $1 / 4$ SW1/4 sec. 1 , T. 32 N., R. 91 W., about 5-20 feet above the Dry Coyote Conglomerate Bed in uraniferous sandstone. A piece of fossil wood that was partly silicified and partly carbonized and that contained 9.36 percent uranium was also found here by the author; this sample, as well as most of the other silicified wood in the formation, is gray to brown, although some wood here is almost white with red and a few other colors. In a small area immediately above the Dry Coyote Conglomerate Bed in $\mathrm{N} 1 / 2$ sec. 12 , T. 32 N., R. 91 W., numerous large pieces of silicified tree logs were found; one piece 1.5 feet in diameter protrudes 10 feet from the enclosing arkosic sandstone.

Carbonized wood and lenses and fragments of carboraceous shale are found in arkosic sandstone as much as 200 feet above the Dry Coyote Conglomerate Bed near the Bullrush and Sagebrush mines. An 8-footthick interval of predominantly carbonaceous material was exposed, in October 1955, along the entire 95-foot length of the Bullrush mine pit, 7 feet above the base of a more than 24-foot-tinick mainly very coarse to coarse-grained conglomeratic arkosic sandstone. The material lies about 95 feet above the Dry Coyote Conglomerate Bed and occurs mainly as stringers of palebrown to grayish-brown carbonaceous shale along bedding in the sandstone. Local concentrations and frag- ments of black carbonized wood have a bleaching effect on the adjacent sandstone for a fraction of an inch in general. One carbonized log several inches in diameter, oriented northwestward, contained 20.74 percent uranium as green and yellowish-green uranium minerals along fractures.

Abundant carbonaceous material, principally in a brown sandy shale bed about 10 inches thick, was noted in a very coarse to coarse-grained arkosic sandstone in a Sagebrush claims pit (NE1/4 NE1/4 NW1/4 sec. 32, T. 33 N., R. 90 W.) 150-200 feet above the Dry Coyote Conglomerate Bed. In and near this shale there were uraniferous black carbonized wood and yellow uranium minerals, mainly autunite.

Most of the carbonized wood described was found only because of the fresh exposures from uranium mining activity, but many such deposits possibly occur throughout the area. In fact, nearly all of the stratigraphic sections and drill holes on which there is reliable information disclosed some carbonaceous shale or carbonized wood.

willow springs Draw to west fork of west Canyon Creek

In this central part of the Gas Hills uranium district (pl. 3) no prominent carbonaceous shales were noted in the Puddle Springs Arkose Member in the few drill holes from which reliable data were available. A few thin carbonaceous shales or claystones of limited extent, however, probably occur here. Thin stringers and fragments of carbonaceous material throughout approximately the lower 200 feet of the Puddle Springs Arkose Member in the main Lucky Mc mine area (secs. 26 and 35, T. 33 N., R. 90 W.) have about the same overall characteristics as those in the Bullrush mine (H. D. Zeller, oral commun., 1959). Between the east and west flanks of the Dutton Basin anticline, carbonaceous shale rests on and a few feet above the Nugget Sandstone (pl.4).

West fork of west Canyon Creek to Rattlesnake Range

In stratigraphic sections $\dot{F} 1$ and F6, (pl. 4), a little carbonaceous material is present, but in other stratigraphic sections of this area none was noted.

Outcrops in area G (fig. 2 ; pl. 4), the part of the undifferentiated Wind River Formation that is equivalent to the Puddle Springs Arkose Member, has some carbonaceous material, for example, in stratigraphic section G3. In drill hole G6, the 34-foot thickness of a carbonaceous shale interval indicates the possibility of a relatively persistent carbonaceous unit at this horizon in the subsurface in the area between Black Mountain and the Rattlesnake Range. Extensive drilling, however, would be required to prove the continuity of such a zone. If the carbonaceous shale is interbedded 
with thick coarse arkose to the south, as is quite possible, large uranium deposits may be associated with it.

EAST CANYON CONGLOMERATE BED

East of the Dutton Basin anticline, a thick coarse conglomerate lies at and near the base of the Wind River Formation (pl. 4). The best exposures are along East Canyon Creek in sec. 4, T. 33 N., R. 89 W.; the unit has been named, therefore, the East Canyon Conglomerate Bed (Soister, 1966c). The conglomerate occurs mostly in the subsurface in the area shown on figure 15 , and it has been penetrated by many drill holes on uranium claims. Surface and drill-hole data indicate that this deposit is only about $2-3$ miles wide, in general, but that it is more than 15 miles long; its long axis is almost due north. This conglomerate was first noted and mapped by Zeller (1958, fig. 18).

In stratigraphic section F2 (pl. 4), boulders in the lower 64 feet of boulder-cobble conglomerate are mostly about 1.5 feet in diameter, but a few are as much as 4 feet in diameter. Rock fragments are mainly white to light-gray granite and white and gray vein quartz. About 23 feet of sandstone, the lower half noncalcareous and the upper half very calcareous, separates this lower 64 feet of conglomerate from 46 feet of cobbleboulder conglomerate which contains the same rock types as the lower part but which also has some black chert fragments. These conglomerate beds and the interbedded sandstone are included in the East Canyon Conglomerate Bed. Moreover, drill-hole data indicate that over much of its area the East Canyon Conglomerate Bed includes thin to thick sandstone lenses.

Above the upper 46-foot-thick unit is 19 feet of hard ledge-forming cavernous-weathering highly calcareous granite granule-pebble conglomerate that grades to a very coarse grained sandstone in places. This unit is undoubtedly equivalent to the upper part of the East Canyon Conglomerate Bed a few miles to the south, but is not considered part of it here. Also the calcareous nature of this unit and of some of the sandstone beds in the coarse conglomerate indicates they are possibly equivalent to finer grained persistent channel sandstone beds farther north toward the middle of the basin.

A short distance south, at stratigraphic section F3 (pl. 4), the conglomerate contains boulders and cobbles of granite, white and gray quartz, dark-gray mafic dike rocks, and gneiss. About 11 feet of very coarse to finegrained highly calcareous sandstone overlying the conglomerate here forms conspicuous ledges; the sandstone has granule-pebble conglomerate interbedded with cobble-boulder conglomerate. This ledge-forming unit is used for correlating between this locality, strat-

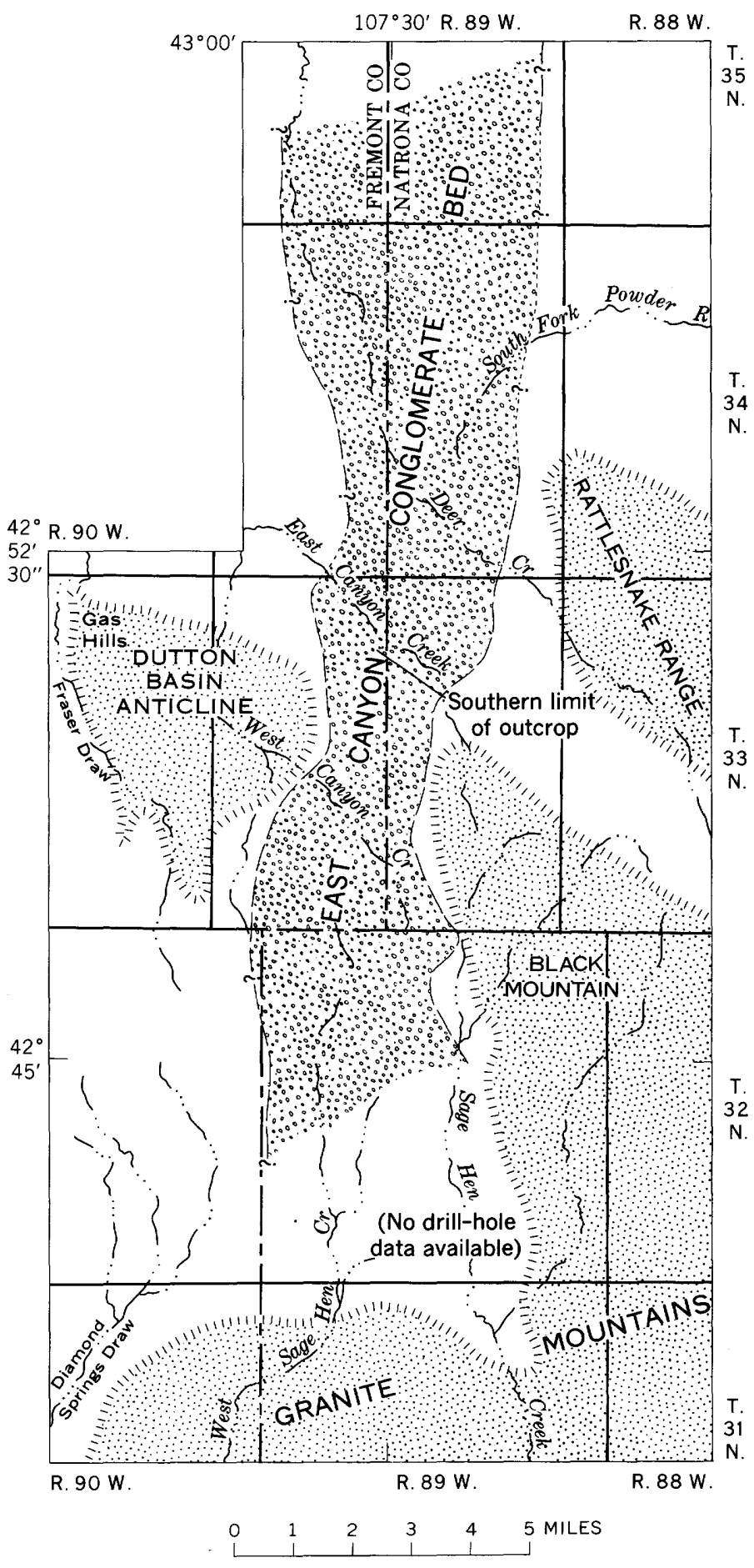

FIGURE 15.-Paleogeographic map showing approximate limits of East Canyon Conglomerate Bed and position of highlands (tipple) during deposition of the sediments. Unpatterned areas are those in which finer grained sediments of the Wind River Formation were deposited. Boundaries of area underlain by East Canyon Conglomerate Bed are queried where highly uncertain and dotted where removed by erosion. Present-day streams shown to aid in location of paleogeographic features. 
igraphic section $\mathrm{F} 2$ to the north, and stratigraphic section F4 to the south; if the correlations are correct, the top of the East Canyon Conglomerate Bed dips below the surface at an elevation of about 6,730 feet at the big bend of East Canyon Creek in the NW1/4 $\mathrm{SE}^{1 / 4} \mathrm{NE}^{1} / 4$ sec. 9 , T. 33 N., R. 89 W.

The conglomerate has been traced in drill holes for at least 6 miles south of its southernmost outcrop on East Canyon Creek. Much of the drill-hole data is sketchy and uncertain, and in some holes, some conglomerate was apparently reported as sandstone; also the coarseness of the conglomerate was generally not reported. In many holes, the conglomerate was too hard to drill through. The top of the conglomerate is especially difficult to determine because of gradation upward into very coarse grained conglomeratic sandstone. In some places the conglomerate is at the base of the Wind River Formation, and in other places it is as much as perhaps 100 feet above it.

Most holes that penetrate the conglomerate show it is 100-300 feet thick. The thickest section was found in company hole 192 on the Russ 8 claim in the NE $1 / 4$ SW $1 / 4$ sec. 27 , T. 33 N., R. 89 W.; the total depth of the hole was 800 feet, of which the lower 700 feet was conglomerate (H. D. Zeller, oral commun., 1958). In this hole, the upper part of the conglomerate is no doubt equivalent to conglomeratic sandstone and other rocks farther north that are stratigraphically higher than the East Canyon Conglomerate Bed, for example, in the Aljob mine area in sec. 15, T. 33 N., R. 89 W.

The southernmost drill hole showing fairly reliable data was drilled by the Sohio Petroleum Co. in the NE $1 / 4$ SW $1 / 4$ sec. 19 , T. 32 N., R. 89 W. (fig. 2). Bruce Kibbler of the Atomic Energy Commission (written commun., 1955) reported 160 feet of coarse conglomerate and "granite wash" with some "shale" in the Wind River Formation at the bottom of this hole. The conglomerate is almost certainly the East Canyon Conglomerate Bed, and the hole is only about 4.5 miles north of the nearest Precambrian outcrops (fig. 2).

The conglomerate decreases in thickness and coarseness northward (T. $34 \mathrm{~N}$. and T. 35 N.). Very little is known, however, regarding the east and west edges and regarding other details of the conglomerate in the area north of the Ervay Basin SW quadrangle. A fairly thick cobble-and-boulder conglomerate on Maverick Butte overlying Cretaceous rocks (H. D. Zeller, oral commun., 1958) is undoubtedly the East Canyon Bed. Toward the east, in sec. 24 , T. 35 N., R. 89 W., and in sec. 19, T. 35 N., R. 88 W., only siltstone and sandstone were noted at about this stratigraphic level. Toward the west, in secs. 19 and 30, T. 35 N., R. 89 W., and in secs. 24 and 25, T. 35 N., R. 90 W., only coarse-grained sandstone was noted in prospect pits (H. D. Zeller, oral commun., 1958). The original east edge of the conglomerate, although now removed by erosion, was probably only a short distance east of Maverick Butte. The present west edge of the conglomerate lies in the Miles Ranch quadrangle. In secs. 4 and 9, T. 34 N., R. $89 \mathrm{~W}$., boulder conglomerate occurs on the banks of Deer Creek. The original west edge was probably no more than 1 mile to the west. If these boundaries are nearly correct, the conglomerate is about 4 miles wide in this northern part. Within this area, and possibly outside it, however, the conglomerate may occur as narrow diverging fingers in coarse arkosic sandstone. Persistent channel sandstone beds and thick coarse poorly to unconsolidated arkosic sandstone occur north of Maverick Butte, and it is postulated that these beds are equivalent to parts of the East Canyon Conglomerate Bed.

In the area of this report, the conglomerate was deposited in a valley largely confined by high positive areas (fig. 15). The streams carrying the coarse debris probably became less competent as they left the steep slopes of the ancestral Granite Mountains; this loss of competency would cause them to drop most of their boulders and cobbles in a short distance and to deposit primarily sediments no larger than pebble size farther north in the more gently sloping parts of the Wind River Basin.

DRY COYOTE CONGLOMERATE BED

The name Dry Coyote Conglomerate Bed (Soister, 1966c) has been given to a sheetlike cobble-boulder conglomerate bed (fig. 16) that is excellently exposed along Dry Coyote Creek. The conglomerate typically forms the resistant caprock on hills and ridges, and it is this characteristic which allows it to be mapped (frontispiece; fig. 17). Its distribution is shown on plate 5 .

This conglomerate is generally recognizable in drill holes because no other persistent conglomerate occurs near it stratigraphically and because it is fairly consistent in lithology and thickness. The Dry Coyote is present in core hole C11 (pl. 3) but is absent in holes drilled to the east, except possibly as a 6-foot-thick conglomerate at a depth of 50 feet in a drill hole in the NW $1 / 4$ SW $1 / 4$ NE $1 / 4$ sec. 34 , T. 33 N., R. 90 W. These data, together with the apparent pinchout observed in the NE $1 / 4$ SE $1 / 4$ sec. 33 , T. 33 N., R. 90 W., allow the drawing of an approximate east limit of the conglomerate for about 3 miles (fig. 11). Apparently, the present northernmost eroded edge of the conglomerate occurs in NW1/4 sec. 29 , T. 33 N., R. 90 W., where it is a granite pebble-cobble conglomerate only 4 feet thick. To the south, in hole C9 (pl. 3), a boulder-cobble conglomerate 53 feet thick at a depth of 355 feet is undoubtedly the 


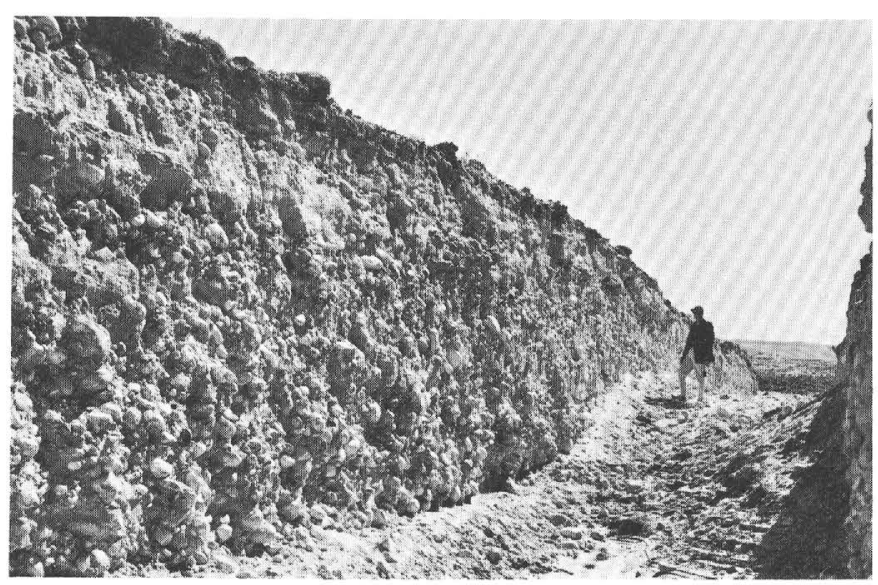

$A$

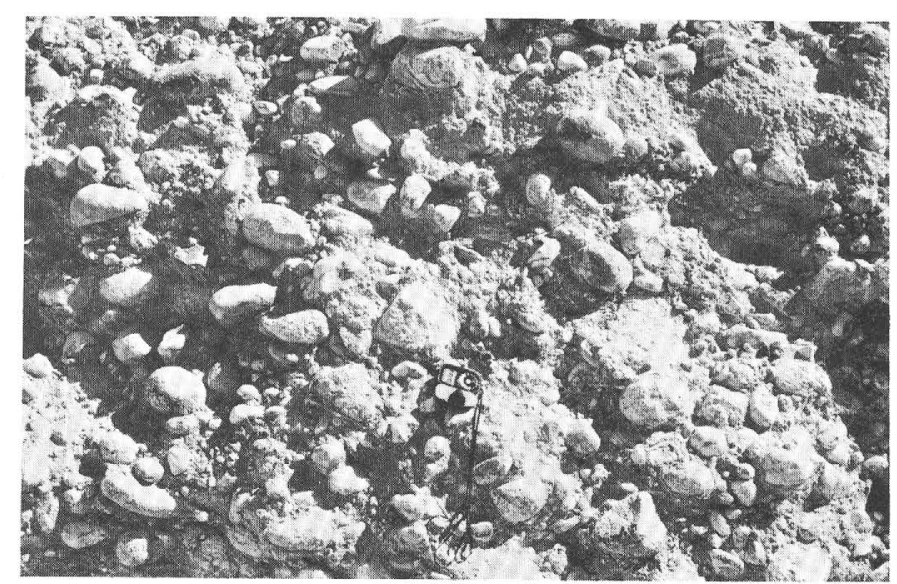

$B$

Figure 16.-Dry Coyote Conglomerate Bed, NW1/4 SW1/4 SW1/4 sec. 32 , T. 33 N., R. 90 W. $A$. Vertical section exposed in a uranium prospect pit. $B$. Closeup of conglomerate showing exfoliation of some cobbles. Photographs by H. D. Zeller.

Dry Coyote Conglomerate Bed. It is much thicker and probably coarser here, nearer the source of the sediments, than at its outcrop 1 mile to the northwest. About $21 / 2$ miles southeast of $\mathrm{C} 9$ in drill holes of the Lisbon Uranium Co. on the Sweetwater Plateau $\left(\mathrm{NE}^{1} / 4 \mathrm{NE}^{1 / 4}\right.$ sec. 21 and SW1/4 sec. 15, T. 32 N., R. 90 W.), a coarse conglomerate 200-260 feet thick (determined by electric logs) forms the lower part of the Wind River Formation (H. D. Zeller, oral commun., 1958). The Dry Coyote Conglomerate Bed in the area east of Muskrat Creek is possibly a tongue from the upper part of this thick channel-filling (?) conglomerate.

In the NW1/4 sec. 15 and NE $1 / 4$ sec. 16 , T. 32 N., R. 91 W., the Dry Coyote Conglomerate Bed is not mappable, but poorly exposed coarse granite fragments and rubble from the siliceous Mowry Shale occur at about its stratigraphic position. Because this rubble from the Mowry
Shale occupies a thicker interval, however, than does the Dry Coyote Conglomerate Bed, the boundaries of the bed close to the overlapped ridges of Mowry Shale cannot easily be defined. Also, lower conglomerates that resemble the Dry Coyote are in sec. 18, T. 32 N., R. 91 W., (55 ft lower), in Atomic Energy Commission core hole 4 (C11, pl. 3) and probably in a few other subsurface localities.

The exposed conglomerate is persistently about 10-30 feet thick. It is thinnest in the north and thickest and coarsest in the southeast (NW1/4 sec. 7, T. 32 N., R. 90 W., and W $1 / 2$ sec. 13, T. 32 N., R. 91 W.), where it is as thick as 35 feet and contains boulders at least 3 feet in diameter. In the NE1/4 SE $1 / 4$ sec. 13, T. 32 N., R. 92 W., the Dry Coyote(?) Conglomerate Bed is 14 feet thick, and in this general area its average thickness is perhaps 10-12 feet. Other conglomerate lenses west of Muskrat Creek that are probably equivalent to the Dry Coyote are about 5-20 feet thick; the long axis of these conglomerate lenses appears to be mostly north-south.

Roundstones in the Dry Coyote Conglomerate Bed are mainly of Precambrian rocks, but fragments of Mesozoic and some Paleozoic rocks are numerous. The principal roundstones are white to light-gray granite; however, white and light-gray vein quartz, light-gray to light-brown quartzite, black chert, and cleavage fragments of white feldspar are very abundant. White chunks, plates, and chips of siliceous Mowry Shale up to at least 2 feet long are abundant north of, but less common south of, the buried and partly exhumed ridges of Mowry Shale. Less numerous roundstones include blue-gray gneissoid quartzite, gray granite gneiss, lightbrownish-gray banded quartzite, deeply weathered dark-gray to dark-green mafic dike rocks, green chlorite and (or) chrome-mica quartzite, schistose quartzite to quartzitic schist, and epidote, all from the Precambrian; hard reddish-brown sandstone from Cambrian and possibly younger rocks; and small ( $3 / 4-11 / 2$ in.) rounded dark-brown to black chert pebbles from conglomerate in the Cloverly Formation. In the NW1/4SW1/4 sec. 12 , T. 32 N., R. 90 W., chert geodes 3 inches in diameter lined with quartz crystals were found. In many places the roundstones, especially of granite, are weathered and exhibit exfoliation after deposition of the sediments (fig. 16B).

The matrix of the conglomerate consists predominantly of very coarse to coarse-grained arkosic sandstone, granules, and pebbles. In some places, however, it is silty or clayey, or the feldspars have been kaolinized so that the matrix is tighter and less permeable. West of Coyote Creek, and especially west of Muskrat Creek, the matrix appears to be more silty and clayey than to the east. 


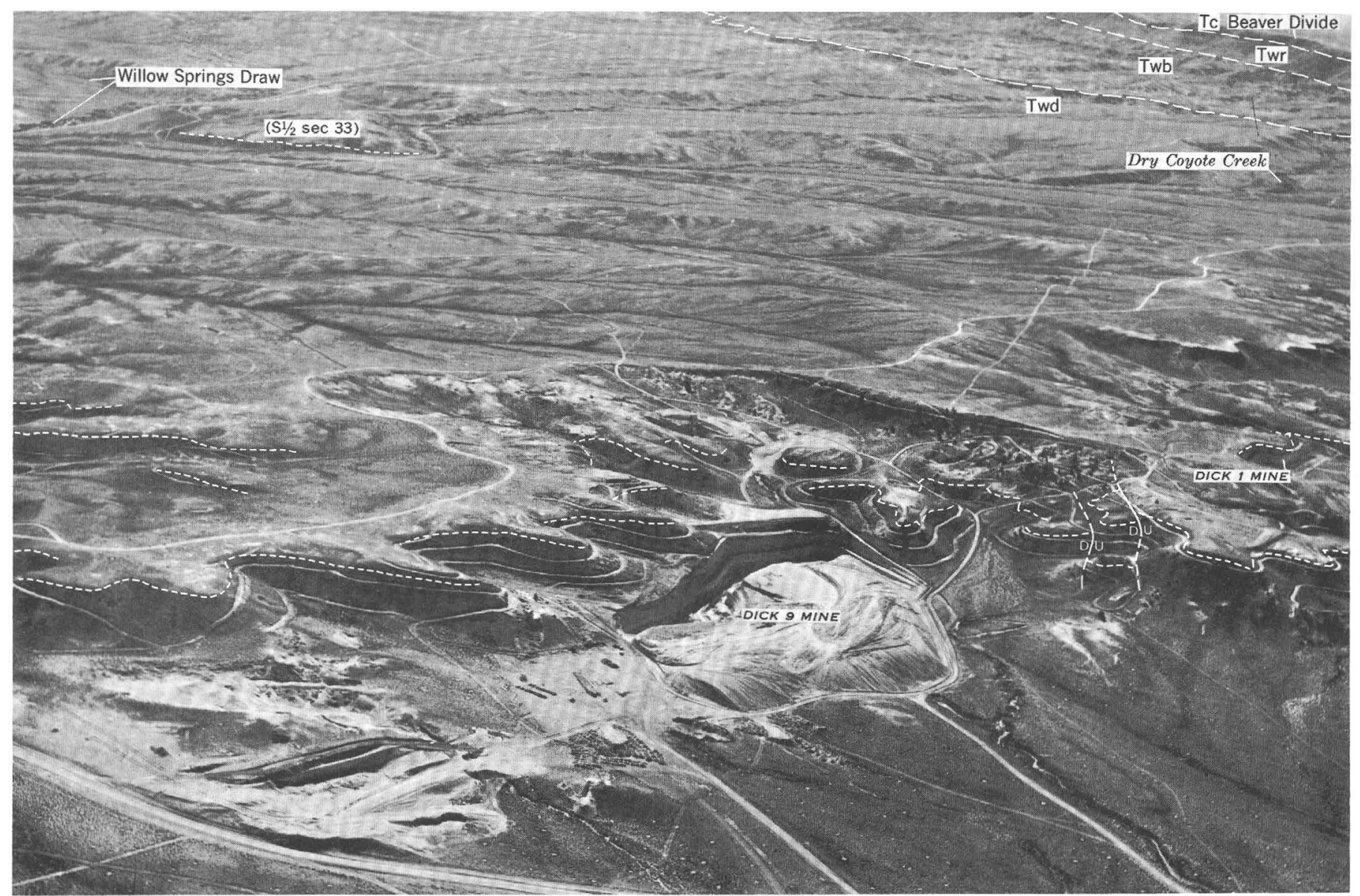

Figure 17.-Dry Coyote Conglomerate Bed in W1/2 sec. 32, T. 33 N., R. 90 W. View is southeastward. Outcrop of Dry Coyote is shown by short dash; Twd, Wind River Formation, undivided; Twb, Wagon Bed Formation; Twr, White River Formation; Tc, conglomerate of Miocene age. Faults shown by solid lines; dashed where probable. Aerial photograph courtesy of Page Jenkins.

Locally, sand increases in the matrix to form lenses of sandstone a few inches to several feet thick in the conglomerate. Such lenses are most numerous west of Muskrat Creek, and one, in sec. 13, T. 32 N., R. 92 W., and sec. 18 , T. 32 N., R. 91 W., covers at least 1 square mile. In sec. 10, T. 32 N., R. 92 W., where the Dry Coyote(?) Conglomerate Bed is about 20 feet thick and has pebbles and small cobbles, the lower 10 feet contains a thin persistent coarse-grained conglomeratic arkosic calcareous sandstone which has low-dipping fluvial crossbedding that indicates northward-flowing currents.

Carbonaceous material is not common in the conglomerate, but there are local occurrences or concentrations, particularly in the upper part or at the top of the conglomerate east of Coyote Creek. Carbonaceous material and silicified wood are more common a short distance above the conglomerate; they have been described in the section "Muskrat Creek to Willow Springs Draw" on page A31.

At the Blarco 1 mine, in the SW1/4SW1/4SW1/4 sec.
12, T. 32 N., R. 91 W., a small uranium-bearing carbonaceous siltstone lens lies in the conglomerate. At the Blarco 3 mine, in the SE1/4SW1/4NW1/4 sec. 12, black charcoallike carbonized wood was found in a sandstone lens in the conglomerate. In the Joy claims area, in the $\mathrm{SW}^{1} / 4 \mathrm{SW}^{1 / 4} \mathrm{NW}^{1} / 4$ sec. 6 , T. 32 N., R. 90 W., the largest amount of carbonaceous material in and adjacent to the conglomerate was found. Here fragments of carbonized wood in the top of the conglomerate included a black carbonized cylindrical tree limb(?) about 1 foot long and 0.3 foot in diameter; a sample of this carbonized wood contained 12.6 percent uranium. Laminated carbonaceous siltstone overlies the conglomerate at this locality. Nearby, at another Joy claim, in the NE1/4 SE $1 / 4^{-}$ NE1/4 sec. 1, T. 32 N., R. 91 W., a tree $\log$ that was apparently completely replaced by uranium minerals ( 42.7 percent uranium reported by Riverton Ranger newspaper) reportedly was mined in August or September 1954 from or just above the conglomerate.

Uranium minerals are abundant in the Dry Coyote 
Conglomerate Bed east of Coyote Creek. Phosphuranylite and other bright-yellow uranium phosphates form a coating on roundstones, particularly on the upper part of a roundstone; commonly, the lower part of the same roundstone is coated by the "uraniferous opal" of field geologists, much of which has been identified as allophane by R. G. Coleman (written commun., 1958). Yellow uranium minerals also occur along weathering cracks in many of these roundstones. Some fragments of the Mowry Shale in the conglomerate contain uranium minerals on surfaces along bedding fractures.

Meta-autunite, another very common yellow uranium mineral, is found in sandstone lenses immediately above or in the conglomerate. Tyuyamunite was identified in a sample from a coarse-grained granulitic arkosic sandstone lens in the conglomerate at the Blarco 1 mine. Yellow uranium minerals also occur in the sandstone matrix of the conglomerate in many places. Uranium minerals coat some roundstones of the conglomerate in most, if not all, of the areas in which uranium occurs in the sandstone matrix or sandstone lenses. Field relations suggest that much of the uranium phosphate coating has been derived by the leaching of these uraniferous sandstones and the downward movement of the uranium-bearing water. Although uranium minerals are extremely common in the Dry Coyote Conglomerate Bed from south of Coyote Springs to the north and northeast, none are known to occur west of Coyote Creek. High radioactivity, however, was noted above this conglomerate near stratigraphic section B3.

\section{MUSKRAT CONGLOMERATE BED}

A prominent boulder conglomerate bed occurs about 90-120 feet above the Dry Coyote Conglomerate Bed west of Coyote Creek (pls. 1, 2, 5). From the good exposures in the vicinity of Muskrat Creek, especially in secs. 15 and 16, T. 32 N., R. 91 W., this deposit was named the Muskrat Conglomerate Bed (Soister, 1966c).

The conglomerate is sheetlike in its area of outcrop. Its exposed east edge is about half a mile west of Coyote Springs, in the W1/2 sec. 14, T. 32 N., R. 91 W. The conglomerate forms the resistant caprock around the north and west edges of a southwest-sloping surface in the northwest quarter of the Coyote Springs quadrangle; it is also conspicuous to the southwest and west on both sides of Muskrat Creek (fig. 14). The conglomerate was mapped from near Coyote Springs to the west edge of the Rongis Reservoir SE quadrangle, and it may persist as far west as the east flank of the Conant Creek anticline. Thompson and White (1952b) and Van Houten (1954) indicated large boulders in approximately the same part of the Wind River Formation in that area. Data from only a few areas of drilling are known to the author, but the conglomerate was reportedly penetrated in drill holes in the following localities: center of the $\mathrm{SW}^{1 / 4} \mathrm{NW}^{1 / 4}$ sec. 14 , the $\mathrm{N}^{1} 1 / 2$ and $\mathrm{W}^{1} 1 / 2$ sec. 31 , and the NW1/4 sec. 33, T. 32 N., R. 91 W.; also, the $\mathrm{S} 1 / 2$ sec. 25, T. 32 N., R. 92 W.

The Muskrat Conglomerate Bed is generally 10-20 feet thick, although it thins and thickens abruptly. On the outcrop, the conglomerate seems to be thickest in the area just west of Muskrat Creek in secs. 19 and 20, T. 32 N., R. 91 W., and secs. 13 and 24, T. 32 N., R. 92 W., where it also contains the greatest number of large boulders.

Roundstones in the conglomerate are mostly boulders and cobbles. In the NW1/4 NW1/4 NW1/4 sec. $14, \mathrm{~T} .32 \mathrm{~N}$., R. $91 \mathrm{~W}$, about $35-45$ boulders on the surface average 6-7 feet in diameter, and several are as large as 9 feet. At the top of sections B3 and B2, and for about 11/2 miles southwest, the conglomerate is composed of boulders, cobbles, and many pebbles, but few boulders are more than 2 feet in diameter. At the south line of the $\mathrm{SW}_{1} 1 / 4 \mathrm{SW} 1 / 4 \mathrm{NW} 1 / 4$ sec. 15, T. 32 N., R. 91 W., there is a huge angular coarse-grained granite boulder, 13 by 8.5 by 6 feet; this boulder must weigh between 35 and 50 tons. In the W1/2 sec. 21 , and the E1/2 sec. 20, T. 32 N., R. 91 W., the boulders average $2-3$ feet in diameter, and some are as much as 5 feet in diameter. Westward from this locality to at least the $\mathrm{E}^{1} / 2$ sec. $14, \mathrm{~T} .32 \mathrm{~N}$., R. $92 \mathrm{~W}$., boulders probably average 1-2 feet in diameter; however, throughout its outcrop in sec. 13 and in the W1 $1 / 2$ sec. 12 , T. 32 N., R. 92 W., the conglomerate contains many boulders $3-5$ feet in diameter and some that are 6 feet or more in diameter. Farther west, in the Rongis Reservoir SE and Muskrat Basin quadrangles, the roundstones decrease in size, and at the base of stratigraphic section A1 the conglomerate contains mainly large cobbles, roughly $6-9$ inches in diameter.

The Muskrat Conglomerate Bed contains relatively fewer roundstones of granite and many more of metamorphic rocks than do the Dry Coyote Conglomerate Bed and conglomerate lenses lower in the section. Granite, gneiss, and gneissoid granite are the predominant types. Most of the large boulders mentioned previously are of light-gray granite or gneissoid granite, some with pegmatitic texture, or of granite gneiss. Fragments at the top of stratigraphic section B2 include bouldersized (and smaller) light-gray gneissoid granite, lightgray granite gneiss, gray chert with a black surface, and quartzitic conglomeratic sandstone probably from the Cloverly Formation; cobble-sized (and smaller) gray quartzite, banded quartzite, and hornblende schist; and pebble-sized green quartzite, black and white cherts, and dark-green mafic dike rocks. At section B3 the conglomerate also contains soft weathered cobbles and 
boulders of dark-green to pale-olive mafic dike rocks and many deeply weathered subrounded to wellrounded small cobbles of white, light-gray, and lightyellowish-gray limestone, in some of which bedding can be seen. In a prospect pit in the $\mathrm{NW}^{1 / 4} \mathrm{SW}^{1 / 4} \mathrm{NE}^{1 / 4}$ sec. 15, T. 32 N., R. 91 W., the conglomerate contained mud balls as much as 3 feet in diameter. West of Muskrat Creek, boulders and cobbles of white quartz and cobbles of white limestone were found in the conglomerate in the NE1/4 sec. 19, T. 32 N., R. 91 W. At the top of stratigraphic section A2 (pl. 2) the conglomerate has very numerous fragments of hormblende schist or gneiss and some serpentine-muscovite gneiss. In the westernmost measured section, A1 (pl. 2), the conglomerate contains mainly gneiss, gneissoid granite, white granite, pink granite, banded biotitic quartzite, green quartzite, chlorite(?) schist, and gray and white vein quartz.

In general, both the matrix and the beds above and below the Muskrat Conglomerate Bed are finer grained than those of the Dry Coyote Conglomerate Bed. Also, the grain size of these materials seems to decrease generally from east to west.

On the outcrop, the conglomerate appears yellowish gray, but it is somewhat mottled owing to the light-gray colors of most roundstones and the generally pale-green to olive-colored matrix.

No uranium minerals have yet been found in or near the Muskrat Conglomerate Bed. Slight radioactivity, however, was measured on the southwest-sloping surface just above this conglomerate in secs. 14 and 15 , T. 32 N., R. 91 W.

\section{OTHER CONGLOMERATE BEDS}

A 10- to 16-foot-thick conglomerate, 55 feet below the Dry Coyote(?) Conglomerate Bed, caps the low hills through the central part of sec. 18, T. 32 N., R. 91 W., west of Sherlock Shearing Pens (sections A4, A5, and A6, pl. 2). Fragments in the conglomerate include mainly white graphic granite, white and red to gray quartz, plates of Mowry Shale as much as 11/2 feet long, small rounded chert pebbles from the Cloverly Formation, angular to subrounded black chert, green quartzite, and brownish-gray quartzite from the Cloverly Formation. The stratigraphic relation this conglomerate bears to the Dry Coyote(?) Conglomerate Bed is the same that the coarse arkosic sediments with the large number of Mowry Shale fragments in section B2 east of Muskrat Creek bears to the Dry Coyote Conglomerate Bed.

In stratigraphic section $\mathrm{A} 5$, another conglomeratic interval lies 18 feet below the conglomerate just described. On the south slope of the hill, about 175 feet west of where section $\mathbf{A} 6$ was measured, a conspicuous channel fill, deposited by a northward-flowing stream, cuts out the entire fine-grained part of A6. Deposits in the channel include siltstone, some brown carbonaceous material, sandstone, conglomeratic sandstone, and conglomerate with granite pebbles, chips of Mowry Shale, black chert, and possibly other rock types. The conglomerate in the lower part of A5 apparently fills part of this channel or another one at the same stratigraphic level; if they are the same channel, the entire channel width is more than 2,200 feet.

In the NW1/4 SE $1 / 4 \mathrm{SE} 1 / 4$ sec. 6, T. $32 \mathrm{~N}$., R. 90 W., an 8 -foot-thick granite small-boulder conglomerate was measured in stratigraphic section $\mathrm{C} 8$ (pl, 3). This conglomerate is of limited extent east and west, has been removed by erosion to the northwest, and probably fills a narrow channel to the southeast.

No coarse conglomerates were noted in drill data from the central part of the area; however, there may be a few lenticular beds of pebble conglomerate. Much of the sandstone here is conglomeratic, and granule conglomerate is common (D5, D6, and D7, pl. 3).

Where the East Canyon Conglomerate Bed occurs, numerous conglomerate and conglomeratic sandstone beds occur above it (fig. 18), but they could not be mapped because of the lack of good exposures. In stratigraphic section F5 (pl. 4), a 32-foot-thick yellowish-gray cobble conglomerate contains cobbles, pebbles, and a few small boulders, mainly of white granite and smaller numbers of white quartz, gray quartz with green stringers, brown chert, and black chert. The top of this conglomerate is at about 6,895-foot elevation in theW1/2W1/2 SW $1 / 4$ sec. 10, T. 33 N., R. 89 W., and

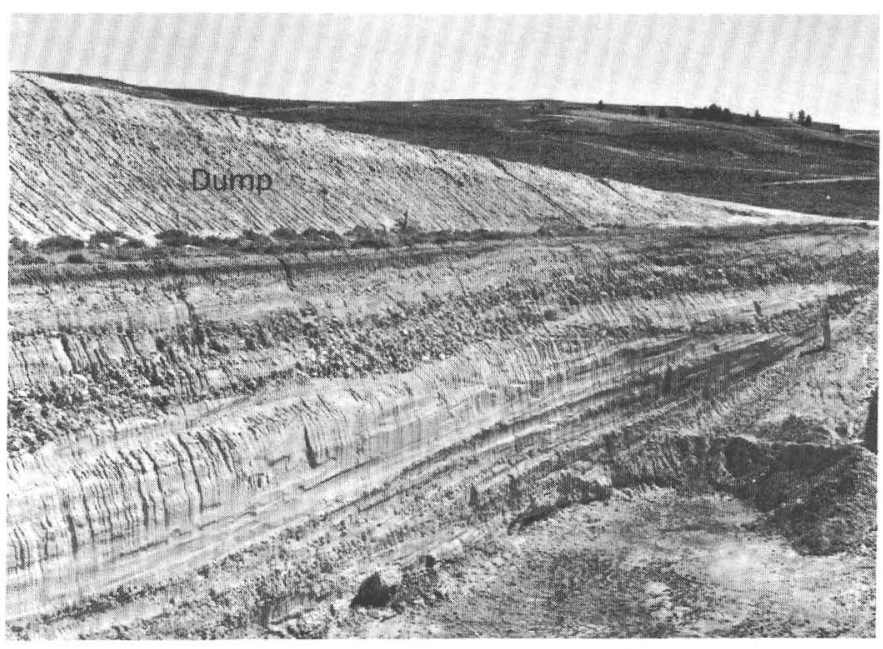

Figure 18.-Conglomerate and sandstone of the Puddle Springs Arkose Member exposed in an open-pit uranium mine, S1/2 SW $1 / 4$ SE $1 / 4$ sec. 15 , T. 33 N., R. 89 W. Note irregularity of the bedding; man for scale between center and right edge. Photograph by H. D. Zeller. 
it may be traceable eastward to the bank of East Canyon Creek in the center of the E1/2 sec. 10. H. D. Zeller (oral commun., 1958) believes a 40 -foot-thick conglomerate (elevation of top it 6,760 ft.) about 12 feet above the definite East Canyon Conglomerate Bed in section $\mathrm{F} 6$, pl. 4) is the same conglomerate. If so, it is probably a tongue from the upper part of the East Canyon Conglomerate Bed and joins it farther south in the subsurface.

East of East Canyon Creek in secs. 11 and 14, T. 33 N., R. $89 \mathrm{~W}$., conglomerate is much less common and forms thinner beds. In stratigraphic section G3 and drill hole G5 (pl. 4), the conglomerate beds include fragments from the Tensleep (?) Sandstone, as well as granite, white quartz, yellow quartz, very fine to finegrained highly glauconitic sandstone, light-gray chert or quartzite, and black, brown, and gray cherts; much of the chert and galuconitic material may be from Cambrian rocks. Fluvial crossbedding in a conglomerate bed and in a very coarse grained conglomeratic arkosic sandstone indicates streams flowed N. $60^{\circ} \mathrm{W}$.

In drill hole G5 ( $\mathrm{pl} .4$ ) very coarse to coarse-grained conglomeratic arkosic sandstone is abundant, but apparently only one pebble conglomerate, about 5 feet thick, was detected. Still farther southeast, at G6, a thick coarse-grained arkosic sandstone was penetrated, but no conglomerate was recorded in the $\log$. Neither of these holes reached the base of the formation, and, therefore, it is not known whether coarser grained beds exist at greater depth in this part of the area.

A Utah Construction Co. drill hole, Q-10 (E1/2 SW1/4 NW1/4 SW1 $1 / 4$ sec. 18 , T. 33 N., R. 88 W.), 2,900 feet eastsoutheast of G5, stopped after penetrating 10 feet of conglomerate at an elevation of about $6,775-6,785$ feet. Another hole, Q-15 (S1/2 SE $1 / 4 \mathrm{SE} 1 / 4 \mathrm{NW}^{1} / 4$ sec. 18) about 4,700 feet due east of G5, stopped after penetrating 15 feet into a conglomerate at an elevation of about $6,725-6,740$ feet. The conglomerate at this elevation may correlate with a 20 -foot-thick granule-pebble conglomerate at 6,720-6,740 feet elevation in G5. The conglomerate in holes Q-10 and Q-15 is probably coarser, however, than that in G5, or drilling would have continued. It is, therefore, postulated that a northwestwardtrending channel-fill conglomerate occurs at depth in the $W 1 / 2$ sec. 18, T. 33 . N., R. 88 W., and could possibly be traced by drilling south-southeastward for several miles toward the area southeast of Black Mountain (fig. 2).

\section{UPPER TRANSITION ZONE}

Less work was done by the writer on the upper 100200 feet than on the rest of the Wind River Formation. Van Houten (1950, 1954, 1955, 1957) made extensive studies of the middle and upper Eocene rocks, which have recently been named the Wagon Bed Formation (Van Houten, 1964), and of the uppermost Wind River beds all along the south edge of the Wind River Basin. His data and interpretations on the upper transition zone of the Wind River Formation were used extensively in the mapping and in the preparation of this part of the report.

Van Houten (1955) placed the top of the Wind River Formation below his unit 1 of the "unnamed middle and upper Eocene rocks" (Wagon Bed Formation). Unit 1 is described as a "tough ledge-forming light greenish-gray mudstone 30 feet thick, containing a thin bed of felsic tuff" (Van Houten, 1955, p. 6). This unit may be as much as 50 feet thick in some localities. It contains generally two, and in some localities as many as four, hard cliff-forming marker beds of tuffaceous sandy mudstone that are generally 1-3 feet thick but locally more than 10 feet thick (fig. 19); in a few places there are no hard cliff-forming beds. Where hard ledgeforming beds are absent and exposures are poor, as in secs. 18 and 19, T. 32 N., R. 90 W., the contact is highly uncertain.

For about 50-150 feet, in general, below Van Houten's unit 1, coarse arkosic sandstone similar to sandstone in the underlying Puddle Springs Arkose Member is interbedded with bentonitic mudstone beds similar to those in the Wagon Bed Formation. This interval of interbedding has been informally designated the transition zone of the Wind River Formation by Van Houten and the upper transition zone by geologists working later in the area. As indicated by Van Houten (1954), the transition zone has no red beds, in contrast to the typically variegated beds of the Wind River Formation where much of the section is composed of claystone and siltstone. The principal outcrop area of this upper transi-

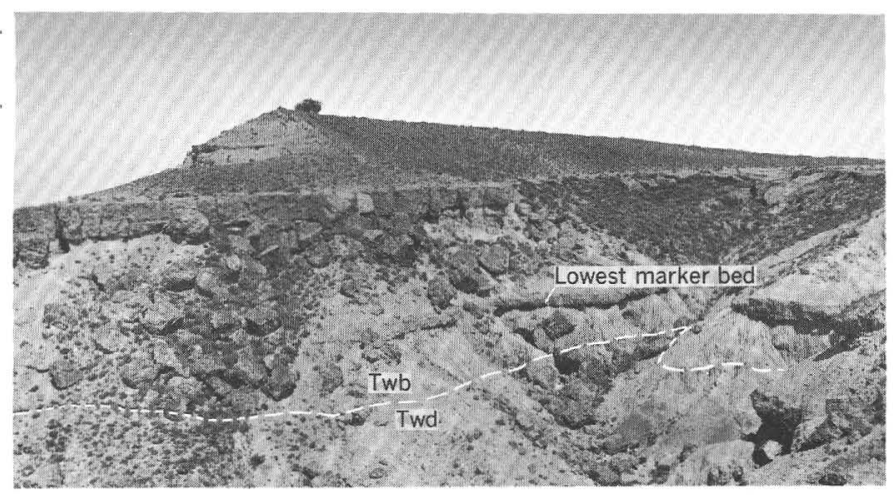

FiguRE 19.-Marker beds in lower part of Wagon Bed Formation (Twb) and part of upper transition zone of Wind River Formation (Twd), NE1/4 sec. 8 , T. 32 N., R. 90 W. Photograph by H. D. Zeller. 
tion zone is along the base of the Beaver Divide escarpment. This zone is not separated from the underlying Puddle Springs Arkose Member on the geologic maps (Soister, 1966a, b; 1967a, b).

A few of the beds in the upper transition zone are cemented by clay, silica, or other material and are hard and ledgy. No calcareous cement has been found in the transition zone or the immediately overlying part of the Wagon Bed Formation. In contrast, most hard beds in the underlying Puddle Springs Arkose Member have calcite cement, except for locally silica- or carbonate fluorapatite-cemented sandstone beds. Colors in the upper transition zone are drab throughout the area: generally grayish yellow green with some pale olive and yellowish gray.

Only two complete surface stratigraphic sections were measured through this zone. At A1 (pl. 2), the westernmost section, the 100 -foot-thick upper transition zone includes about 79 percent mudstone, claystone, and siltstone, 14 percent very fine to medium-grained sandstone, and 7 percent very coarse to coarse-grained sandstone. At this locality, the highest red band in the Wind River Formation lies 108 feet below the top of the formation. The 199-foot-thick red-banded part of the Wind River Formation underlying the transition zone here is composed of about 66 percent siltstone and claystone, 19 percent very fine to medium-grained sandstone, and 15 percent very coarse to coarse-grained conglomeratic sandstone. Most of the Wind River Formation in this part of the area is fine grained.

In stratigraphic section C10 (pl. 3), Van Houten's unit 1 of the Wagon Bed Formation is 37 feet thick and has a 1- to 3-foot thick hard marker bed 8 feet above its base and a 10-foot marker bed at the top. Fine-grained rocks in the transition zone of the Wind River Formation makes up less of the section here than farther west. The highest calcareous bed in the Wind River Formation here is 113 feet below the top of the formation, or only a few feet below the transition zone. There are no red beds in the upper part of the formation at this locality.

Farther east, along the foot of the Beaver Divide escarpment, in secs. 9, 10, and 11, T. 32 N., R. 90 W., Van Houten's unit 1 of the Wagon Bed Formation is quite conspicuous because of three or four hard ledgeforming marker beds. The transition zone of the Wind River Formation, however, is poorly developed or absent. In drill hole D6, (pl. 3), the top of which is about 30 feet above the lowest marker bed, the highest red band in the formation is only 37 feet below the presumed formational contact. Most of the Wind River beds below this contact are coarse-grained arkosic sand- stone that is partly to highly argillaceous. Very little tuffaceous mudstone typical of the transition zone was noted in the drill core. In drill hole D7, the highest red band is only 27 feet below the apparent contact of the Wind River and White River Formations. The Wagon Bed Formation probably was removed by erosion immediately before deposition of the White River Formation in a deep valley here. Although most of the rocks in the drill hole are sandstone, numerous mudstone galls, but no beds of mudstone, were found in the upper 85 feet of the Wind River Formation. For all practical purposes, the upper transition zone may be considered to be absent in $\mathrm{D} 6$ and possibly in $\mathrm{D} 7$.

Still farther east, a larger amount of claystone and siltstone or mudstone occurs in the uppermost part of the Wind River Formation. In drill hole F10, (pl.4) the upper 155 feet of the formation was logged as almost entirely mudstone and siltstone, and the highest red band is only 8 feet below the contact. In another hole (W1/2 SE1/4 NW1/4 sec. 22 , T. 33 N., R. 89 W.), green and red mottled mudstone 120 feet thick lay immediately below 30 feet of beds similar to Van Houten's unit 1 of the Wagon Bed Formation (H. D. Zeller, oral commun., 1958). The writer has not closely examined the uppermost part of the formation in the central and eastern parts of the area, but the red-banded fine-grained beds here should not be included in the transition zone. Rather, they are considered part of the typical variegated beds of the Wind River Formation that intertongue with the Puddle Springs Arkose Member. Van Houten (1955, p. 5) described "carbonaceous shale about 60 feet below the top of the Wind River formation in $\mathrm{SW}^{1 / 4} \mathrm{NE}^{1 / 4}$ sec. 27, T. $33 \mathrm{~N}$. R. 89 W." This shale also is typical of the fine-grained beds lower in the Wind River Formation, and no carbonaceous shale has been found in or near the upper transition zone in the area of this report.

East of the inlier of Paleozoic rocks in secs. 22, 23, and 26, T. 33 N., R. 89 W., the contact between the Wind River Formation and the Wagon Bed Formation is along the base of the Beaver Divide escarpment; here, information on the uppermost part of the Wind River is lacking because of faults, extensive cover, and scanty drill-hole data.

\section{SOURCE OF SEDIMENTS}

All available evidence indicates that most of the sediments of the Wind River Formation in this area came from within the area itself and immediately to the south, with the exception of the tuffaceous material in the upper transition zone, which came from the northwest. 
Sediments of the lower fine-grained member where best exposed, in the vicinity of Sarcophagus Butte, include a large amount of fine- to medium-grained light-gray quartzose sand that is apparently reworked and whose source was the Mesozoic formations about 2-3 miles to the southeast. These formations, which had formed ridges and valleys, include the Cloverly, Morrison, Sundance, and Nugget. Near the base of the lower finegrained member in this vicinity are numerous hard white to light-gray chips derived from the Mowry Shale, which formed ridges about $11 / 2^{-2}$ miles east and southeast of Sarcophagus Butte. Invariably, these chips are in the same beds that contain smooth, rounded $1 / 2^{-}$ to $1 \frac{1}{2}$-inch dark-brown to black chert pebbles from conglomerate in the Cloverly Formation. Commonly these chips and pebbles are in a matrix of the previously mentioned reworked quartz sand.

These same kinds of chips and pebbles occur at and near the base of the formation throughout most of the Puddle Springs quadrangle and in the Rongis Reservoir SE quadrangle and were derived from west-trending ridges of the Cloverly and Mowry Formations along and just south of these quadrangles. That these ridges were relatively high is shown by the large plates of Mowry Shale and boulders of quartzitic sandstone from the Cloverly. Presumably, most of the finer grained sediments, silt and clay, in adjacent beds also had their source in the same general sequence of pre-Tertiary rocks, including the Frontier Formation. Because the carbonaceous beds contain leaf imprints, which indicate little, if any, transportation, most of the carbonaceous material in these beds was undoubtedly deposited near its origin.

Above the reworked Mesozoic sediments in the lower fine-grained member, fine- to coarse-grained arkosic sandstone and siltstone with dark-gray and dark-green biotite and (or) chlorite flakes are the most abundant rock types; the Precambrian core of the ancestral Granite Mountains, about 10-15 miles to the south, was the source of this material. The Paleozoic formations also probably contributed sediments, but such material is masked by the great amount of Precambrian debris.

The Puddle Springs Arkose Member is composed of predominantly coarse arkosic sedimentary rocks and contains roundstones mainly of light-gray to white granite, some of it graphic granite, identical to that found in the present Granite Mountains. Other coarse particles include metamorphic rocks, also from the Granite Mountains, and some fragments of limestone, sandstone, and chert, all from Paleozoic formations that were on the north flank of the ancestral Granite Mountains and are now mostly buried by the Wind River and younger formations. Some glauconite grains in the
Puddle Springs Member were derived from the highly glauconitic Sundance Formation and have been reworked; other grains near Black Mountain were probably derived from the Cambrian rocks (Gros Ventre? Formation) very close by.

The silicified wood that is abundant in the conglomerate near the base of the formation and that is more abundant near the Dry Coyote Conglomerate Bed and also many of the carbonized wood fragments that are in the coarse arkosic sandstone show signs of transportation. Some of this material was probably carried by streams from higher on the flank of the ancestral Granite Mountains. Many of the plants grew very near where the carbonaceous material is now found, however, as evidenced by relatively large to small lenticular carbonaceous beds and the concentration of carbonaceous material in certain intervals of the formation.

In the upper transition zone of the Wind River Formation, arkosic material from the Precambrian core of the ancestral Granite Mountains diminishes in amount and coarseness, and finer-grained material, possibly from the Paleozoic rocks along the north flank of the mountains, is present. Van Houten (1955, p. 12-13) wrote that volcanic material in this interval increases to the west and suggested that the source was probably volcanoes in the Absaroka-Yellowstone region northwest of this area. Hay $(1956$, p. 1891) suggested that the prevailing winds during the volcanism were from the northwest, and such winds would explain the transportation of the fine ash and dust to this area and the eastward decrease in amount of this material.

\section{DEPOSITIONAL ENVIRONMENT}

\section{PALEOGEOGRAPHY}

In the area studied, the sediments of the Wind River Formation were deposited on a surface cut on pre-Tertiary rocks along the north flank of the ancestral Granite Mountains. The erosion surface sloped mainly northward but had generally east-trending ridges and valleys eroded on interbedded hard and soft strata that dipped to the north. The Dutton Basin anticline and other flexures had been breached by erosion, so that resistant beds formed cuestas and hogbacks and intervening soft beds formed valleys or swales; most of the ridges and valleys associated with folds trend northward, northwestward, or northeastward. The thick soft Cody Shale formed a gently sloping and undulating plain over most of the Puddle Springs and Rongis Reservoir SE quadrangles and in the northeastern part of the area.

Besides the Cody Shale, valley-forming beds include mainly black shale that makes up most of the Frontier 
Formation, the Thermopolis Shale, and soft beds in the Chugwater Formation. The Thermopolis Shale formed valleys in this area because it lies between the very resistant Mowry and Cloverly Formations, and its Muddy Sandstone Member is poorly developed or absent. Good examples of the valleys formed on the Thermopolis are along the west flank of the Dutton Basin anticline and in the upper Muskrat Creek area (p. A27).

Ridge-forming post-Precambrian rocks included the sandstone in the Frontier Formation, the siliceous Mowry Shale, the Cloverly Formation, the Nugget Sandstone, the Alcova Limestone Member and other hard beds in the Chugwater Formation, the Tensleep Sandstone, the Madison Limestone, and the hard Cambrian sandstones. Minor ridges were probably held up by thin sandstone beds in the Cody, Morrison, Sundance, and Amsden Formations and by thin dolomite or dolomitic siltstone beds in the Phosphoria Formation. Gaps were cut through the ridges, particularly the westtrending ones, by streams that deposited their sediments farther out in the basin. The greatest relief from ridge top to valley bottom occurred generally where the dip of the beds was greatest, and locally in such places the relief was more than 300 feet.

North of the Gas Hills-Puddle Springs area, the Cody Shale and younger Mesozoic rocks and the Fort Union Formation of Paleocene age formed an undulating plain with minor ridges and swales. This plain sloped northward across most of the present Wind River Basin to the basin's lowest part. Throughout most or all of Wind River time, the lowest part of the basin was probably at or just south of the east trending structural axis, which lies near its north edge and only a few miles south of the present Owl Creek Mountains. W. R. Keefer (written commun., 1963) stated that this "was a closed basin during earliest Eocene time because of folding of the Casper Arch [and that] as the basin filled up with sediments later in early Eocene time, eastward-flowing drainage probably was reestablished."

Perhaps the earliest statement on diastrophism during Wind River time was by Hayden (1862), who stated that "after the crust broke, the country continued slowly rising while the Wind River deposits were accumulating ***." Blackstone (1948, p. 76) wrote, "The principal deformation which outlined the major structural features [of the Wind River Basin] occurred in post-Paleocene $* * *$ and pre-Lower Eocene time. Further diastrophic spasms continued with attendant volcanism through the Eocene time." W. R. Keefer. however, (written commun., 1963) postulated that the "major uplift of the Granite Mountains began in latest Cretaceous time," and that "along the north and east edges of the basin, most pronounced diastrophism took place at a stage of earliest Eocene time"; he concluded that no blanket statement can be made as to the time of diastrophism. Love (1960, p. 208) wrote that "Early Eocene was the time of some of the most widespread and intense crustal deformation in Wyoming." In summary, diastrophic movements prior to Wind River time gave the Wind River Basin its present general outlines, but important diastrophic movements also occurred during deposition of the sediments.

During Wind River time the Wind River Basin was almost entirely surrounded by the ancestors of the mountains that now surround it, and on the east, ridges on the Casper Arch stood above the basin floor. Van Houten (1952, p. 74) believed that the nearby Big Horn Basin floor was "probably not more than 1,000 feet above sea level $* * *$ [but] $* * *$ the mountain crests may have stood as much as 3,000-5,000 feet above the basin floor." Van Houten (1957, p. 79) also believed that the Wind River Basin floor "was about 1,000 feet above sea level" during early Eocene time.

The approximate relative height of the ancestral Granite Mountains may be ascertained by reconstructing the original surface at the base of the Wind River Formation. Initially the Wind River beds probably dipped an average of about 50 feet per mile northward, in this area, but they now dip an average of about 140 feet per mile southward; thus, the total southward tilting has been about 190 feet per mile. Net throw on the east-trending normal faults is approximately zero because the total throw on those downthrown to the north is about the same as the throw on those downthrown to the south; thus, the faults are disregarded in these calculations. The Wind River Formation rests on the Cody Shale at an altitude of 5,940 feet about 4 miles north of Puddle Springs Ranch; 18 miles south Precambrian rock outcrops are at an altitude of 6,750 feet, only 810 feet higher. In the 18 miles, the southward tilting totals about 3,400 feet $(190 \times 18)$; the additional 810 feet of present relief gives a figure of about 4,200 feet. From these calculations, one may confidently conclude that the south edge of the area of this report was at least 4,000 feet higher than the north edge of the Puddle Springs quadrangle. The surface existing at the beginning of deposition of the Wind River Formation in this area was roughly comparable with that at the base of the formation shown in the southern onethird of figure $5 B$.

Because of erosion during and after deposition of the Puddle Springs Arkose Member, the figures given here for the relative height of the mountains are minimum figures. Also the central and higher part of the ancestral Granite Mountains was apparently 5-6 miles farther south. From the foregoing data and inferences, 
the writer believes that the highest part of the ancestral Granite Mountains stood at least 5,000 feet, and possibly as much as 6,500 feet, above the Puddle Springs area during deposition of the Puddle Springs Arkose Member. Part of this height was probably attained by uplift in Puddle Springs time. If the Wind River Basin floor was, in general, about 1,000 feet above sea level, the main area of deposition of the Puddle Springs Arkose Member may have been about 2,0003,000 feet above sea level, and the ancestral Granite Mountains, about 7,000-9,000 feet above sea level.

The probability of a large eastward-flowing river in the Wind River Basin was first suggested by Wortman (1892, p. 143), who believed that such a stream existed during deposition of the Wasatch Formation sediments in the Big Horn Basin in pre-Wind River time and that the Wind River Formation sediments were deposited in a lake after the outlet of this stream had been cut off by uplift. Evidence of an eastward-flowing stream along the north edge of the basin during Wind River time has been cited by many later workers: Sinclair and Granger $(1911$, p. 87$)$; Love $(1939$, p. 107) who said it probably flowed into the Powder River Basin; Tourtelot and Thompson (1948), who said the channel sandstones in the north-central part of the basin "maintain their eastward trend as far east as the vicinity of Arminto (T. 37 N., R. 87 W. ***);" and Rich (1962), who noted sedimentary structures indicating eastward-flowing streams in sandstones in the northeastern part of the basin.

The only possible outlets for streams from the ancestral Wind River Basin were in the extreme northwest and southeast corners of the basin or to the east across the Casper Arch. The geology of the first two of these areas (Love, 1939, 1947; Keefer, 1955, 1957; Rich, 1962) apparently eliminates them as outlets. From the evidence however, it is postulated that possibly during Lysite time, in all probability during Lost Cabin time, and, therefore, during the time of deposition of most of the Wind River sediments in the area of this report, a major river flowed eastward near the north edge of the basin and across the northern part of the Casper Arch (fig. 1) to join a northward-flowing river in the Powder River Basin.

Channel sandstones of the Wasatch Formation in the Pumpkin Buttes area of the Powder River Basin were mapped by the author in 1952 and 1953. These sandstones are typically about 40 feet thick, of limited east-west extent but at least several miles long northsouth. Scutes and other remains of garpike, including one partial skeleton $11 / 2$ feet long, were found in the sandstones. The discovery of garpike in sandstones of the Wind River Basin (Sinclair and Granger, 1911, p. 91) suggests a similar en'vironment in these two basins.
Crossbedding in the sandstones of Pumpkin Buttes indicated north-northwestward-flowing streams, and it was inferred by the present author that the streams that deposited the sand flowed in that direction from the north edge of the Laramie Range and the Hartville uplift. The age relation of these sandstones with the Lysite and Lost Cabin Members of the Wind River Basin has not been definitely determined; however, the occurrence of Lambdotherium near the top of the Wasatch Formation at Pumpkin Buttes suggests Lost Cabin age for at least the upper part of the Wasatch there. The following fossils are also found throughout most of the Wasatch Formation (F. C. Whitmore, Jr., written commun., Dec. 19, 1966).

Faunal List

Pumpkin Buttes, Wyoming,

North side of Dome Butte,

Sec. 2, T. 44 N., R. 76 W.

Specimens collected by J. D. Love and M. L. Troyer :

Homogalax upper premolars and molars.

Phenacodus upper molar and premolar, fragments of other teeth.

Coryphodon upper molar, part of premolar, canine.

Specimens collected by Jean Hough, R. L. Hay, and Robert DeMar :

Hyracotherium last lower molar.

Lambdotherium lower milk molar.

Coryphodon several molars, fragments of molars, limb bones and incisors.

The probable contemporaneity of large rivers in the Wind River and Powder River Basins, together with their location and direction of flow, leads to the conclusion that these rivers joined west or southwest of the Pumpkin Buttes area in the Powder River Basin.

\section{PALEOCLIMATE}

The climate of the Wind River Basin or adjacent regions during part or all of Wind River time has been variously interpreted as humid and subtropical, humid and warm-temperate, arid, subarid, recurrently moist and subarid, and glacial. Several criteria have been used as evidence of the climate, such as the lack of weathering of feldspars in arkosic sediments, coarse and poorly sorted conglomerates, red beds, types of fossil mammals, abundance of fossil reptiles, types of fossil plants, and swamp deposits.

Loomis (1907, p. 361) believed that the red banding in sedimentary rocks in the Wasatch Formation of the Big Horn Basin was probably due to oxidation of iron because of "alluvial deposits being exposed to the sun, the vegetation cover being scantier and the effect of the heat greater." Osborn (1909, p. 21) believed the Tertiary began “*** with a moderately warm and 
humid but far from tropical climate, with mild winters ***"; however, he believed $(1910$, p. 93$)$ that during the early Tertiary on the Pacific coast "Tropical conditions still prevailed up as far as Alaska $* * *$ as evidenced by the abundant coal deposits there. Osborn also stated (1910, p. 129) that "The wide horizontal extent of the red bands is attributed to prolonged or repeated periods of flooding; the red color is less probably due to aridity or other atmospheric causes than to erosion from the Triassic rocks."

Sinclair and Granger $(1911$, p. 113) believed that the freshness of feldspar and other fragments of granitic rocks "does not favor the idea of luxuriant Eocene tropical forests and a warm humid climate, with the formation of a deeply decayed regolith, but suggests a dry, not necessarily arid, climate with rapid changes of temperature to splinter the parent ledges, and rapid transportion of the fragments for short distances ***." Also they (p. 116) "ascribe the color banding $* * *$ to $* * *$ the alternation of moist and dry climatic conditions but [had] not found any evidence of excessive aridity, the fauna of the red and blue bands being the same." They believed the "blue clays" to represent moist cycles and the "red clays" to represent dry cycles, during which "the iron salts" oxidized to produce the red colors.

Blackwelder (1915, p. 109) quoted Sinclair and Granger and wrote that his observations with regard to the undecayed feldspars and red bands "tend to confirm this hypothesis of floodplain deposition, under subarid or steppe conditions." Osborn $(1929$, p. 9) mentioned the "warm temperate climate of the Green River lake period, and evidently arid conditions in the contemporary Wind River sediments. Alternation of arid and fluviatile conditions [is] characteristic of Wind River and Wasatch time."

Berry (1930, p. 60) wrote that "plants of the Green River flora either in Green River Basin or Wind River Basin would be perfectly at home somewhere in the region between South Carolina and Louisiana ***." Hence they should be called warm-temperate and not tropical. Also the characteristics in petrified wood indicate that seasonal contrasts were not extreme.

Atwood and Atwood (1938, p. 961) believed that "In the mountains of the Eocene period, alpine glaciers formed." They cited "several heavy bouldery deposits believed to be Eocene till * * *" near Alcova, at the southeast end of the basin. The characteristics of the deposits which led them to believe in a glacial origin are "physical heterogeneity, lithological variety, and lack of assortment." No further reference to the possibility of Eocene glaciation in this region has been found by the present author, who concludes from the descriptions that these deposits may represent nonglacial boulder-filled mudflows at the edge of steep, high mountains.

Love (1939, p. 107), in describing the earliest Eocene deposits in the Wind River Basin, the Indian Meadows Formation in the northwestern part of the basin, wrote that the abundance of algae, invertebrates, fish, turtle bones, and crocodile teeth suggests a humid climate.

Van Houten (1945, p. 444) wrote that "early Cenozoic floras, instead of indicating aridity, point to a humid, warm-temperate, lowland environment in the Rocky Mountain region." He reiterated this belief in a later report (1952, p. 74) and mentioned "a humid warm-temperature to subtropical savanna-like lowland ***" $(1957$, p. 83$)$.

According to Van Houten (1948, p. 2114), arkose does not necessarily indicate a dry climate because it "forms almost independent of climate. In humid regions it accumulates under conditions of deep dissection of granite and rapid transportation and burial * * *."

The use of red beds as invariable evidence of dry climate has been invalidated. Osborn $(1910$, p. 129) apparently was the first geologist concerned with these rocks who disputed this as evidence. Tourtelot (1948, p. 117) and other geologists besides the writer have noted the lateral gradation of red beds into lithologically similar green, gray, or bluish beds; this relationship indicates that all the beds must have been deposited under the same climatic conditions. The presence in red beds of abundant vertebrate and invertebrate fossils, many of which are not waterworn (Love, 1939 , p. 107), and turtle and crocodile scraps, "usually associated with red gravelly sandstones," (Kelley and Wood, 1954, p. 337) in the Lysite area also casts doubts on the theory for an arid origin of the red beds and a humid origin of the drab-colored beds. Tourtelot $(1948$, p. 117) reported that more fossil vertebrates are found in the variegated Lost Cabin deposits in the type locality than in the adjacent drab facies. Kelley and Wood (1954, p. 337) noted that most collections of mammals were made in beds of mottled purple, red, and white, or in fine white sandstones.

Love (1939, p. 107) believed that most of the red color must have been the result of conditions of deposition. Van Houten (1945, p. 444) wrote that the recurrence of "large terrestrial mammals in variegated sediments and $* * *$ small arboreal forest animals in drab deposits and gray layers in the variegated sediments ***" suggests $6 * * *$ that the gray layers accumulated in swampy lowlands, while the red layers were deposited on flood plains in savannahs that displaced the wooded areas from time to time." The presence of large numbers of animals, some of them aquatic, indicates that the 
climate was not arid when the red sediments were deposited.

Some geologists (Osborn, 1910, p. 129; Tourtelot and Thompson, 1948; Love, 1956, p. 144; Keefer, 1957, p. $190)$ believe that the coloring materials in red beds came from thick red formations, such as the Chugwater Formation of Triassic age, which were being eroded at the edges of the basin. In the south-central Wind River Basin, all the red beds in the Wind River Formation are in areas which could have received sediments from older red beds, the Phosphoria Formation of Permian age as well as the Chugwater Formation.

Van Houten (1948) made an extensive study of the origin of red beds in lower Cenozoic rocks of the Rocky Mountain region, and he admitted that "red beds may have locally supplied the pigments of some red layers in the varicolored deposits." He added, however, (p. 2115) that "extension of some of the red-banded formations marginward so that they overlap Mesozoic red-bed formations and rest on older rocks $* * *$ suggests that locally variegated sediments accumulated ***" after such possible sources of red coloring material had been buried. Van Houten also (p. 2083) believed that almost all the red coloring material was derived from red upland soil that developed during a warm humid climate and "that in deposits which accumulated in more open country of a savannah environment the primary red color was preserved, while in sediments accumulating in heavily forested areas drab colors resulted from reduction of the hematite by incorporated plant debris."

Evidence cited by Walker (1967) indicates the red coloring material from red upland soils would be masked by other sediments of the depositing streams. Probably, the color of these thin red beds is a result of oxidation of the sediments, during and shortly after their deposition, as a result of the local nature of the vegetation and the position of the ground-water table. The savannah environment cited by Van Houten (1945, p. 444; 1948, p. 2083) seems reasonable.

Further evidence that the climate of this area was not arid includes the lack of mud cracks, according to Van Houten $(1948$, p. 2103) ; however, most beds are probably too poorly consolidated to have retained mud cracks. The author has seen no mention in the literature of the apparent lack of eolian crossbedding in the sandstones anywhere in the basin. If such structures were common, as they should be in sandstones deposited under arid conditions and reworked by the wind, they would probably have been cited by at least one of the numerous geologists who have studied the Wind River Formation.
Probably the most generally accepted idea of climatic conditions of the Rocky Mountain region throughout Tertiary time is about as stated by Osborn $(1909, \mathrm{p} .21)$ : "Opening with a moderately warm and humid *** climate, with mild winters, $* * *$ progressive elevation, slowly progressing aridity, $* * *$ and progressively sharper definition of winter and summer seasons." More recently, Dorf (1960) discussed Tertiary climates of North America, particularly from late Eocene time to the present. He showed that during most of Tertiary time, including the early Eocene, climatic zones were much farther north than comparable zones are today, and he indicated that Wyoming had a subtropical to warm temperate climate in early Eocene time.

During early Eocene time, a long shallow arm of the sea extended up the present Mississippi Valley from the Gulf of Mexico (Schuchert and Dunbar, 1947, fig. 251) and brought warm marine water perhaps 200 miles closer to the Wind River Basin than at present. Also the Rocky Mountain region in general and the Wind River Basin in particular stood at much lower altitudes, although the Granite Mountains were slightly higher then than now. These factors must have induced greater rainfall, considerably lower evaporation, warmer and more even temperatures, and much less seasonal change in the main part of the Wind River Basin than at the present time. The flora and fauna of the Wind River beds have been described by paleobotanists and vertebrate paleontologists as typical of a region similar to the southeastern United States of today (Berry, 1930, p. 60), and, therefore, a somewhat similar climatewarm temperature and slightly to moderately humid with mild winters-probably existed in the Wind River Basin during early Eocene time.

If, as presumed, much of the rainfall in this region came northwest from the Gulf of Mexico, the southern part of the Wind River Basin may have had less rainfall than the northern part because of the rain-shadow effect of the ancestral Laramie Range to the east and more particularly the Granite Mountains immediately to the south. The ancestral Owl Creek Mountains, although perhaps relatively lower than today (J.D. Love, written commun., 1963), may have had a similar effect so that rainfall in the northern part of the basin was greater and enough to support a permanent eastwardflowing stream and a favorable environment for the various animals now found in large numbers as fossils. The swamp deposits, however, in the area of this report indicate at least a moderate amount of rainfall in the southern part of the basin during at least some of Wind River time. 


\section{DEPOSITION OF SEDIMENTS}

During earliest Eocene time, sediments were being deposited in the central part of the Wind River Basin while the area of this report was being eroded. A few thousand feet of sediments now assigned to the Wind River Formation accumulated in the deeper parts of the basin before deposition began near the south-central edge. As the central part of the basin became filled, sediments eventually lapped onto the flanks of the surrounding highlands. Erosion of the older formations on these flanks continued until most of them were overlapped by the encroaching sediments.

The overlapping relations are particularly evident in the southern and southeastern part of the Puddle Springs quadrangle and the northern part of the Coyote Springs quadrangle (Soister, 1967a, b). About 3 miles southwest of Coyote Springs, the Muskrat Conglomerate Bed lies at the base of the Wind River Formation over the hard ridge-forming Cloverly Formation. Just north of Coyote Springs, the Dry Coyote Conglomerate Bed, approximately 100 feet stratigraphically lower than the Muskrat, lies just above the base of the formation over a ridge of Mowry Shale; $31 / 2$ miles northnortheast (at C2, pl. 3), this conglomerate lies 427 feet above the base. Thus, there is about 525 feet of thinning by overlap from northeast to southwest in this part of the area in about 6 miles and about 425 feet of thinning southward to the ridge of Mowry Shale in less than 4 miles. Figure 6 illustrates this southward thinning onto ridges of resistant rocks by showing the thickness of the formation below the Dry Coyote Conglomerate Bed.

Along the flanks of the Dutton Basin anticline, along the Rattlesnake anticline, and near the northwestprojecting spur of Black Mountain, now represented by the inlier of Paleozoic rocks (Ervay Basin SW quadrangle), thinning of the Wind River Formation onto high ridges amounted to several hundred feet per mile.

During erosion of the south-central part of the Wind River Basin in earliest Wind River time, northwardflowing streams were vigorous enough to remove virtually all sediments from the area and deposit them farther north. As the stream gradients decreased, probably owing both to erosion of the high areas and filling up of the lower basin areas to the north, gravel and sand derived almost entirely from the Mesozoic rocks were deposited by the northward-flowing streams. The conglomerate at and near the base of the Wind River Formation (p. A16) apparently was deposited by vigorous streams with fairly high gradients and not by mudflows, because the matrix is fairly well sorted sand containing very little silt or clay, and some boulders are at least 6-8 miles from their source. With further decrease of gradient, streams became less vigorous and most of the material transported and deposited was of medium sand-grain size or smaller; in the area near Puddle Springs and westward, fine-grained material from the Precambrian rocks of the ancestral Granite Mountains was included, but the material deposited west of and within about 2 miles of the west flank of the Dutton Basin anticline was almost entirely derived from the Mesozoic rocks. Silt and clay were deposited on flood plains and in small lakes or ponds along the streams.

Small swamps were scattered over the area, most commonly after deposition of the basal gravel. Such swamps were most persistent along the west and southwest flanks of the breached Dutton Basin anticline, where they were protected from stream erosion by the ridges of Mesozoic rocks. The most widespread swamp deposit preserved is the central carbonaceous zone (fig. 11) that lies at and just below the top of the lower fine-grained member.

The thickest known carbonaceous bed in the area does not crop out but was penetrated by drill holes south of Coyote Springs in secs. 14, 15, 22, 23, and 24, T. 32 N., R. 91 W. (p. A18; figs. 2, 9). This carbonaceous interval indicates that a swamp existed for a considerable time south of a ridge of Mowry Shale, at or shortly after the time of the swamp of the central carbonaceous zone. It probably occupied a valley between the ridge of Mowry Shale on the north and a ridge of the Cloverly, Nugget, or Chugwater Formation on the south; drill-hole data are not available to indicate the east or south edge of the swamp deposit. Other swamps existed where the Cody Shale was below the Wind River Formation, and in this part of the area the general relief of the pre-Wind River surface was low, as shown particularly by the thick carbonaceous interval in secs. 18 and 19, T. 33 N., R. 90 W. (p. A18; fig. 8B) and by a few scattered small beds of carbonaceous shale in the Rongis Reservoir SE and Puddle Springs quadrangles.

As erosion of the north flank of the ancestral Granite Mountains proceeded, more gaps were cut through the cuestas and hogbacks of Mesozoic and Paleozoic rocks. Consequently, during deposition of mainly the upper part of the lower fine-grained member, granitic debris from the Precambrian core of the mountains became more generally available to the northward-flowing streams, and the coarse arkosic sand of the channel sandstones was deposited in the adjacent lowlands, along with other arkosic and micaceous sand and silt.

Cutting of these gaps through the Paleozoic and Mesozoic rocks and canyon-cutting closer to the high parts of the mountains probably was hastened by renewed elevation of the entire Sweetwater uplift in 
Wind River time. Evidence of thrusting and elevation of the Sweetwater uplift during early Eocene time is cited by Knight (1937) and Bell (1950, p. 1550). Diastrophism mainly in or near the western part of the basin during early Eocene time has been reported by Love $(1938 ; 1939$, p. $107 ; 1956$, p. 144), Tourtelot and Nace (1946), Tourtelot and Thompson (1948), and Van Houten $(1954 ; 1957$, p. 79 ), and specifically in Wind River time by Sharkey, Zapp, Johnson, and others (1946), Murphy and Roberts (1954), Troyer and Keefer (1955), Keefer (1955; 1957, p. 208), and Murphy, Privrasky, and Moerlein (1956).

This movement of the Sweetwater uplift caused a great mass of very coarse arkosic material to be eroded from the ancestral Granite Mountains and deposited on a piedmont alluvial fan along the north flank of the mountains. This coarse arkosic material constitutes the Puddle Springs Arkose Member; most of the material that still remains in the area, after the extensive Quaternary erosion, was carried only about 5-12 miles from its source. Deposition was largely in channels of swift, possibly intermittent, streams that dropped their loads as they flowed northward toward the lowest part of the Wind River Basin and entered the major eastwardflowing river about 25-30 miles to the north.

In the eastern part of the area, the thick coarse arkosic materials of the East Canyon Conglomerate Bed filled a north-trending channel that was cut between the flanking highlands of Black Mountain and the ridges of the breached Dutton Basin anticline (figs. 2, 15). The stream that cut this deep channel may have eroded some older Wind River beds including the lower fine-grained member. As the stream left the steep flanks of the mountains and debouched onto the gentler slopes farther from the highlands, it dropped the very coarse gravels near the break in slope and spread coarse arkosic sand farther north.

Gravels making up the Dry Coyote and Muskrat Conglomerate Beds were deposited by streams that probably flowed through water gaps in ridges of Paleozoic and Mesozoic rocks and dropped their loads on the more gentle slopes of the alluvial fans being built up on the lower slopes and at the foot of the mountains. Thick deposits of coarse arkosic sand were formed by these and similar streams, and the thinning of coarse units and the finer grained nature of the sediments northward indicate an abrupt loss of competency of the streams in that direction.

Sediments composing the Dry Coyote Conglomerate Bed east of Muskrat Creek may have been deposited by the distributary system of one main northwestwardflowing stream; the generally very coarse sand matrix indicates vigorous stream flow. The gravel and sand were deposited over low areas at the foot of the mountains and in some valleys along the lower slopes. In places, ridges of resistant pre-Tertiary rocks stood above the plains of deposition; for example, in secs. 20 and 21 , T. 32 N., R. 91 W., a ridge of the Cloverly Formation stood at least 100 feet high at this time. Rock fragments derived from these ridges, especially from the ridge of Mowry Shale, which was partly overlapped by this conglomerate, were added to the gravel. Most of the coarse material in the Dry Coyote(?) Conglomerate Bed west of Muskrat Creek probably was carried northward through separate canyons from the mountains.

Sediments composing the Muskrat Conglomerate Bed were deposited as a broad apron along the flank of the mountains apparently by streams flowing from several canyons and through several water gaps in the Paleozoic and Mesozoic rocks. Inasmuch as the coarse material was furnished simultaneously to these streams to form this sheetlike deposit, it is postulated that this and the other major conglomerate beds are the result of intervals of rapid uplift within a period of general uplift of the ancestral Granite Mountains. According to Knight (1937, p. 84), the very coarse conglomerates of early Eocene age on Green Mountain and Crooks Mountain, on the south flank of the Sweetwater uplift, were deposited during similar tectonic activity.

The Muskrat Conglomerate Bed contains coarser debris than the Dry Coyote Conglomerate Bed. Many of the boulders and cobbles in the Muskrat are angular, whereas those in the Dry Coyote are generally rounded. Inasmuch as the coarse particles in both beds traveled about the same distance and had about the same weathering conditions the coarse particles in the Muskrat must have been in transit a shorter time than those in the Dry Coyote. Also, the Muskrat Conglomerate Bed generally has a finer grained matrix that includes much silt and clay, as well as some mudstone balls, whereas the Dry Coyote Conglomerate Bed has a matrix mainly of very coarse grained sand. Deposition of the materials forming the Muskrat may, therefore, have been largely by mudflows.

In some places, conglomerate beds are overlain by fine-grained sediments, some of them carbonaceous. A good example of this is the carbonaceous siltstone and shale above the Dry Coyote Conglomerate Bed in sec. 6, T. 32 N., R. 90 W., approximately along the channel of the main stream which deposited the gravel. This sequence is another indication that the conglomerate beds, where they now crop out, were deposited mainly at the foot of the mountains-at the break in slope from the mountains to the plains area where swamps would form-and not high on the flanks of the mountains. 
Fine-grained beds, mainly greenish siltstone and claystone with some thin reddish-brown claystone, intertongue with the coarse arkosic sediments of the Puddle Springs Arkose Member. These fine-grained beds make up most of the formation west of Muskrat Creek and also east of the area underlain by the East Canyon Conglomerate Bed. From these relations, it is obvious that the principal area of the piedmont alluvial fan lay between the present position of Muskrat Creek on the west and the Black Mountain highland on the east.

West of the main alluvial fan area, sediments similar to those of the lower fine-grained member were being deposited in the same manner and under almost the same conditions as prevailed earlier, but more granitic debris was being carried into the area along the channels of minor streams from the south; also the intermittent uplift of the mountains caused deposition of interbedded coarse debris. North of the ridge of Mowry Shale, which probably trended west approximately at the $42^{\circ} 45^{\prime}$ parallel, the area was mainly open grasslands and flood plains, with a few small swamps. Much of the formation has been stripped from this area, however (Soister, 1966b), and more extensive swamps may have existed during part of Wind River time.

Some fine-grained sediments deposited within the main piedmont alluvial fan area indicate that deposition probably was partly in small lakes or ponds on flood plains along the basinward edges of the fan. Some localities in which clay and silt were deposited were protected from stream erosion by hills of pre-Tertiary rocks; such a locality is typified by the very local deposits of thick green- and red-banded siltstone and claystone in the Vitro John mine area (W1/2 sec. 25 and $\mathrm{E} 1 / 2$ sec. 26 , T. 33 N., R. 90 W.). Other fine-grained sediments were deposited in valleys between ridges of hard rocks, particularly the east-west-trending valleys which were normal to the principal drainage.

The erosion of the ancestral Granite Mountains and the raising of the basin floor by rapid deposition of sediments of the Puddle Springs Arkose Member as alluvial fans brought about a reduction in the gradient of the streams. Therefore, probably in latest early Eocene time and possibly in earliest middle Eocene time (Van Houten, 1955 , p. 6), a large proportion of the sediments deposited were fine grained-silt, clay, or mud-and interbedded with thin layers of stream-deposited arkosic sand. This material included some volcanic dust and fine ash (Van Houten, 1955, p. 5, 12) that was probably blown from the Yellowstone-Absaroka volcanic region, about 150 miles to the northwest, by the prevailing winds (Hay, 1956, p. 1891). Interbedding and mixing of the normal clastic sediments and the tuffaceous ma- terial resulted in the upper transition zone of the Wind River Formation. Deposition was on broad flood plains, or perhaps partly in broad shallow lakes as postulated by Van Houten $(1955$, p. 13) for the lowest unit of the overlying middle Eocene rocks (Wagon Bed Formation). Although rocks of the upper transition zone have been removed by erosion everywhere except at the edge of the basin, their fine-grained texture here indicates the possible existence of such a broad shallow lake farther north in the basin.

\section{STRATIGRAPHIC POSITION OF URANIUM DEPOSITS}

All known uranium deposits of the Gas Hills uranium district, totaling at least 10 million tons of ore, lie in areas $\mathrm{B}, \mathrm{C}, \mathrm{D}, \mathrm{E}, \mathrm{F}$, and $\mathrm{G}$ of figure 2. The district has been divided by geologists of the Atomic Energy Commission into a central, western, and eastern "ore trend" (H. D. Zeller, oral commun., 1957). The central "ore trend" contains at least half the known reserves, and the remaining reserves are about evenly divided between the western and eastern "ore trends." H. D. Zeller (written commun., 1961) has provided information on the approximate proportion of reserves within these three "ore trends" and on the stratigraphic position of deposits in the central and eastern parts of the district. Most of the information on the western "ore trend" is based on the writer's observations through 1958.

In the western "ore trend," about 75 percent of the ore reserves occurs in area $\mathrm{C}$ (fig. 2) and the remaining 25 percent in area $\mathrm{B}$; there are no known deposits in the Muskrat Basin or Rongis Reservoir SE quadrangles. In the central "ore trend," about 99 percent of the ore occurs in area $\mathrm{D}$, and the remaining 1 percent (one deposit) is in area E. In the eastern "ore trend," about 99 percent of the known reserves is in the south half of area $\mathrm{F}$, and the remaining 1 percent is in area $\mathrm{G}$. Throughout the district, approximately the lower half of the Puddle Springs Arkose Member contains most of the known uranium ore reserves.

In the western "ore trend" almost all the known reserves occur from about 150 feet stratigraphically below the Dry Coyote Conglomerate Bed to about 50 feet above it. The large deposit at the Dick 9 mine lies 132-145 feet below the conglomerate (C3, pl. 3), and the mined-out Bullrush deposit was $40-50$ feet above the conglomerate (C2, pl. 3). Numerous deposits, most of them small, lie in or within a few feet above or below the conglomerate. This common association of uranium with the Dry Coyote produces a somewhat linear northnortheast-trending belt which coincides with the outcrop of the conglomerate (Soister, 1958, fig. 24). Deposits south of Coyote Springs are probably stratigraphically near the conglomerate. Significantly, also, a very 
thick carbonaceous shale zone (fig. 9) lies below the large uranium deposits in this area south of Coyote Springs.

In the central "ore trend" (fig. 2, area D), the largest uranium deposits of the district lie in about the lower 200 feet of the Puddle Springs Arkose Member. Subbituminous coal and carbonaceous shale of the central carbonaceous zone, at and near the top of the lower fine-grained member, is mineralized at the first Lucky Mc mine (D3, pl. 3; fig. 10); this zone forms the apparent lower limit of uranium deposits in area $\mathrm{D}$. The area underlain by the central carbonaceous zone (fig. 11) contains the very large deposits of the central "ore trend."

In the eastern "ore trend" most of the known uranium reserves are about 200 feet above the East Canyon Conglomerate Bed. Some deposits have been found, however, in this conglomerate. The deposit in area $\mathrm{E}$ (fig. 2) occurs in probably about the same general part of the stratigraphic section as those above the East Canyon. Sedimentary rocks containing this deposit probably were deposited in channels which cut through hogbacks of the pre-Tertiary formations on the flanks of the breached Dutton Basin anticline.

Consideration of where uranium deposits are unknown or are very small is important in understanding their stratigraphic distribution. In the area of this report there are no known deposits west of Muskrat Creek, and only a few small deposits are known east of the north end of the Black Mountain highland area. In these areas (fig. 2, areas $A$ and $G$ ), the Wind River Formation consists mainly of fine-grained beds interbedded with fewer thin beds of coarse-grained rocks. There are no known deposits in the upper transition zone or in the lower fine-grained member, except for those at the top of the lower member in the central "ore trend"; these parts of the formation also have large amounts of fine-grained rocks. In addition, uranium deposits are virtually unknown in coarse-grained arkosic channel sandstone beds and in other north-dipping strata north of the area of this report; this single fact is one of the best indications that the large uranium deposits were formed after post-Miocene faulting and southward tilting in the south-central part of the basin.

Additional uranium deposits probably lie south of the known deposits. These probably occur mostly in the Wind River Formation several hundred to a thousand feet or more below the surface. Possibly, others may exist at comparable depths in the southern part of, and south of, area A (fig. 2), and in the southeast part of area $G$ between Black Mountain and the Rattlesnake Range.
The author believes that the coarse-grained porous and highly permeable nature of the Puddle Springs Arkose Member in areas B through $\mathbf{F}$ (fig. 2) is the most important single factor contributing to the occurrence of uranium deposits in this district, except for the source of the uranium; the coarse arkose itself is the most likely source. Other factors contributing to the occurrence of large uranium deposits include the formation of subsidiary basins by post-Miocene faulting, aquifuges (mainly pre-Tertiary rocks in fault or erosional contact), aquicludes (mainly fine-grained beds in the Wind River Formation), and the presence of precipitating agents including carbonaceous materials. Moreover, the southward tilting and downfaulting into subsidiary basins by subsidence of the Sweetwater uplift has allowed the uranium to accumulate more rapidly than the coarse arkosic sediments could be removed by Quaternary erosion.

\section{REFERENCES CITED}

Atwood, W. W., and Atwood, W. W., Jr., 1938, Working hypothesis for the physiographic history of the Rocky Mountain region: Geol. Soc. America Bull., v. 49, no. 6, p. 957-980.

Bell, W. G., 1950, Problems of the structure and stratigraphy of the upper Sweetwater Valley, west-central Wyoming [abs.] : Geol. Soc. America Bull., v. 61, no. 12, p. 1549-1550.

Berry, E. W., 1930, A flora of Green River age in the Wind River Basin of Wyoming: U.S. Geol. Survey Prof. Paper 165-B, p. 55-81.

Blackstone, D. L., Jr., 1948, The structural pattern of the Wind River Basin, Wyoming, in Wyoming Geol. Assoc. Guidebook 3d Ann. Field Conf., Wind River Basin, 1948: p. 69-78.

Blackwelder, Eliot, 1915, Post-Cretaceous history of the mountains of central western Wyoming: Jour. Geology, v. 23, p. 97-117, 193-217, 307-340.

Bogrett, J. W., 1954, Geologic map and structure sections of the northern end of the Rattlesnake Hills, Natrona County, Wyoming, in Wyoming Geol. Assoc. Guidebook 9th Ann. Field Conf., Casper area, 1954.

Carey, B. D., Jr., 1954a, Geologic map and structure sections of the Rattlesnake Hills Tertiary volcanic field, Natrona County, Wyoming, in Wyoming Geol. Assoc. Guidebook 9th Ann. Field Conf., Casper area, 1954.

$-1954 b$, A brief sketch of the geology of the Rattlesnake Hills, in Wyoming Geol. Assoc. Guidebook 9th Ann. Field Conf., Casper area, 1954 : p. 32-34.

Coleman, R. G., and Erd, R. C., 1961, Hydrozircon from the Wind River Formation, Wyoming, in Geological Survey research, 1961 : U.S. Geol. Survey Prof. Paper 424-C, p. C297-C300.

Collier, A. J., 1920, Gas in the Big Sand Draw anticline, Fremont County, Wyoming: U.S. Geol. Survey Bull. 711-E, p. 7583.

Cope, E. D., 1882, On the vertebrates of the Wind River Eocene beds of Wyoming: U.S. Geol. Geog. Survey Terr. Bull., v. 6, p. 183-202.

Dorf, Erling, 1960, Climatic changes of the past and present: Am. Scientist, v. 48, p. 341-364. 
Endlich, F. M., 1878, Part of central Wyoming [geologic map] : U.S. Geol. Geog. Survey Terr. (Hayden) 12th Ann. Rept., Maps and Panoramas.

1879, Report on the geology of the Sweetwater district: U.S. Geol. Geog. Survey Terr. (Hayden) 11th Ann. Rept., p. 5-158.

Goddard, E. N., chm., and others, 1948, Rock-Color Chart: Washington, Natl. Research Council (Repub. by Geol. Soc. America, 1951), $6 \mathrm{p}$.

Granger, Walter, 1910, Tertiary faunal horizons in the Wind River Basin, Wyoming, with descriptions of new Eocene mammals: Am. Mus. Nat. History Bull., v. 28, p. 235-251.

Hares, C. J., 1916, Anticlines in central Wyoming: U.S. Geol. Survey Bull. 641-I, p. 233-279.

Hay, R. L., 1956, Pitchfork formation, detrital facies of early basic breccia, Absaroka Range, Wyoming: Am. Assoc. Petroleum Geologists Bull., v. 40, No. 8, p. 1863-1898.

Hayden, F. V., 1862, Some remarks in regard to the period of elevation of those ranges of the Rocky Mountains near the sources of the Missouri River and its tributaries: Am. Jour. Sci., 2d ser., v. 33, p. 305-313.

- 1878, Wasatch group, in General notes, geology, and paleontology : Am. Naturalist, v. 12, p. 831 .

Keefer, W. R., 1955, Geologic map of the Du Noir area, Fremont County, Wyoming: U.S. Geol. Survey Oil and Gas Inv. Map OM-166.

— 1957, Geology of the Du Noir area, Fremont County, Wyoming: U.S. Geol. Survey Prof. Paper 294-E, p. 155-221.

Kelley, D. R. and Wood, A. E., 1954, The Eocene mammals from the Lysite Member, Wind River formation of Wyoming: Jour. Paleontology, v. 28, no. 3, p. 337-366.

Knight, S. H., 1937, Origin of the giant conglomerates of Green Mountain and Crook's Mountain, central Wyoming [abs.] : Geol. Soc. American Proc. 1936, p. 84 .

1954, Stages in the Cenozoic history of central Wyoming, in Wyoming Geol. Assoc. Guidebook 9th Ann. Field Conf., Casper area, $1954:$ p. 35-36.

Loomis, F. B., 1907, Origin of the Wasatch deposits: Am. Jour. Sci. 4th ser., v. 23, p. 356-364.

Love, J. D., 1938, Age of structural features along the northwestern margin of the Wind River Basin, Wyoming [abs.] : Geol. Soc. America Proc. 1937, p. 97.

1939, Geology along the southern margin of the Absaroka Range, Wyoming: Geol. Soc. America Spec. Paper 20, 134 p.

- 1947, Tertiary stratigraphy and its bearing on oil and gas possibilities in the Jackson Hole area, northwestern Wyoming: U.S. Geol. Survey Oil and Gas Inv. Prelim. Chart 27.

1954, Preliminary report on uranium in the Gas Hills area, Fremont and Natrona Counties, Wyoming: U.S. Geol. Survey Circ. 352, 11 p.

—_ 1956, Summary of geologic history of Teton County, Wyoming, during Late Cretaceous, Tertiary, and Quaternary times, in Wyoming Geol. Assoc. Guidebook 11th Ann Field Conf., Jackson Hole, 1956 : p. 140-150.

1960, Cenozoic sedimentation and crustal movement in Wyoming: Am. Jour. Sci., v. 258-A (Bradley volume), p. 204-214.

Love, J. D., Weitz, J. L., and Hose, R. K., 1955, Geologic map of Wyoming : U.S. Geol. Survey.

Masursky, Harold, 1962, Uranium-bearing coal in the eastern part of the Red Desert area, Wyoming: U.S. Geol. Survey Bull. 1099-B, 152 p.
Meek, F. B., 1876, A report on the invertebrate Cretaceous and Tertiary fossils of the upper Missouri country: U.S. Geol. Geog. Survey Terr. (Hayden), Rept. 9, 629 p.

Meek, F. B., and Hayden, F. V., 1861, Descriptions of new Lower Silurian (Primordial), Jurassic, Cretaceous, and Tertiary fossils, collected in Nebraska [Territory] ***, with some remarks on the rocks from which they were obtained: Acad. Nat. Sci. Philadelphia Proc., v. 13, p. 415-447.

Murphy, J. F., 1956, Uranium-bearing water in the Crow Creek and Muskrat Creek areas, Fremont County, Wyoming: Wyoming Geol. Survey Rept. Inv. 5, 15 p.

Murphy, J. F., Privrasky, N. C., and Moerlein, G. A. 1956, Geology of the Sheldon-Little Dome area, Fremont County, Wyoming: U.S. Geol. Survey Oil and Gas Inv. Map OM-181.

Murphy, J. F., and Roberts, R. W., 1954, Geology of the Steamboat Butte-Pilot Butte area, Fremont County, Wyoming: U.S. Geol. Survey Oil and Gas Inv. Map OM-151.

Nace, R. L., 1936, Summary of the late Cretaceous and early Tertiary stratigraphy of Wyoming: Wyoming Geol. Survey Bull. 26, $271 \mathrm{p}$.

Osborn, H. F., 1909, Cenozoic mammal horizons of western North America; with faunal lists of the Tertiary mammalia of the West, by W. D. Matthew : U.S. Geol. Survey Bull. 361, 138 p. 1910, The age of mammals in Europe, Asia, and North America : New York, The Macmillan Co., 635 p.

1929, The titanotheres of ancient Wyoming, Dakota, and Nebraska: U.S. Geol. Survey Mon. 55, v. 1 p. 1-701: v. 2. p. 703-953.

Pipiringos, G. N., 1955, Tertiary rocks in the central part of the Great Divide Basin, Sweetwater County, Wyoming, in Wyoming Geol. Assoc. Guidebook 10th Ann. Field Conf., Green River Basin, 1955: p. 100-104.

Rich, E. I., 1962, Reconnaissance geology of Hiland-Clarkson Hill area, Natrona County, Wyoming: U.S. Geol. Survey Bull. 1107-G, p. 447-540.

St. John, O. H., 1883, Report on the geology of the Wind River district: U.S. Geol. Geog. Survey Terr. (Hayden) 12th Ann. Rept., pt. 1, p. 173-269.

Schuchert, Charles, and Dunbar, C. O., 1947, A textbook of geology, pt. 2, Historical geology [4th ed.]: New York, John Wiley and Sons, Inc., $544 \mathrm{p}$.

Sharkey, H. H. R., Zapp, Alfred, Johnson, C. O., and others, 1946, Geologic and structure contour map of Sage Creek dome, Fremont County, Wyoming: U.S. Geol. Survey Oil and Gas Inv. Prelim. Map 53.

Simpson, G. G., 1933, Glossary and correlation charts of North American Tertiary mammal-bearing formations: Am. Mus. Nat. History Bull., v. 67, art. 3, p. 79-121.

Sinclair, W. J., and Granger, Walter, 1911, Eocene and Oligocene of the Wind River and Bighorn Basins [Wyoming] : Am. Mus. Nat. History Bull., v. 30, art. 7, p. 83-117.

Soister, P. E., 1958, Preliminary stratigraphy of Wind River formation in Gas Hills area [Wyoming] : U.S. Geol. Survey TEI-740, p. 112-120. [For sale by Clearinghouse for Federal Sci. and Tech. Inf., Natl. Bur. Standards, U.S. Dept. Commerce, Springfield, Va.]

1966a, Geologic map of the Muskrat Basin quadrangle, Fremont County, Wyoming: U.S. Geol. Survey Misc. Geol. Inv. Map I-482 [1967].

1966b, Geologic map of the Rongis Reservoir SE quadrangle, Fremont County, Wyoming: U.S. Geol. Survey Misc. Geol. Inv. Map I-483 [1967]. 
Soister, P. E., 1966c, Puddle Springs Arkose Member of Wind River Formation, in Cohee, G. V., and West, W. S., Changes in stratigraphic nomenclature by the U.S. Geological Survey, 1965: U.S. Geol. Survey Bull. 1244-A, p. 42-46.

1967a, Geologic map of the Coyote Springs quadrangle, Fremont County, Wyoming: U.S. Geol. Survey Misc. Geol. Inv. Map I -481 .

- 1967b, Geology of the Puddle Springs quadrangle, Fremont County, Wyoming: U.S. Geol. Survey Bull. 1242-C, $36 \mathrm{p}$.

Thompson, R. M., and White V. L., 1952a, Geology of the Conant Creek-Muskrat Creek area, Fremont County, Wyoming: U.S. Geol. Survey open-file report.

1952b, The coal deposits of the Alkali Butte, the Big Sand Draw, and the Beaver Creek fields, Fremont County, Wyoming: U.S. Geol. Survey Circ. 152, $24 \mathrm{p}$.

Tourtelot, H. A., 1948, Tertiary rocks in the northeastern part of the Wind River Basin, Wyoming, in Wyoming Geol. Assoc. Guidebook 3d Ann. Field Conf., Wind River Basin, 1948: p. 112-124.

1953, Geology of the Badwater area, central Wyoming: U.S. Geol. Survey Oil and Gas Inv. Mas OM-124.

Tourtelot, H. A., and Nace, H. L., 1946, Tertiary stratigraphy and its bearing on oil and gas possibilities in the northeastern part of the Wind River Basin, Wyoming: U.S. Geol. Survey Prelim. Chart 22.

Tourtelot, H. A., and Thompson, R. M., 1948, Geology of the Boysen area, central Wyoming: U.S. Geol. Survey Prelim. Oil and Gas Inv. Map 91 (repr. 1955).

Troyer, M. L., and Keefer, W. R., 1955, Geology of the Shotgun Butte area, Fremont County, Wyoming: U.S. Geol. Survey Oil and Gas Inv. Map OM-172.

Van Houten, F. B., 1945, Review of latest Paleocene and early Eocene mammalian faunas: Jour. Paleontology, v. 19, p. $421-461$.

— 1948, Origin of red-banded early Cenozoic deposits in Rocky Mountain region: Am. Assoc. Petroleum Geologists Bull., v. 32, no. 11, p. 2083-2126.

1950, Tertiary stratigraphy of the western part of the Beaver Divide area, Fremont County, Wyoming: U.S. Geol. Survey Oil and Gas Inv. Map OM-113.

1952, Sedimentary record of Cenozoic orogenic and erosional events, Bighorn Basin, Wyoming, in Wyoming Geol. Assoc. Guidebook 7th Ann. Field Conf., southern Big Horn Basin, 1952: p. 74-79.
1954, Geology of the Long Creek-Beaver Divide area, Fremont County, Wyoming: U.S. Geol. Survey Oil and Gas Inv. Map OM-140.

- 1955, Volcanic-rich middle and upper Eocene sedimentary rocks northwest of Rattlesnake Hills, central Wyoming: U.S. Geol. Survey Prof. Paper 274-A, p. 1-14.

1957, Tertiary rocks of southern Wind River Basin area, central Wyoming, in Wyoming Geol. Assoc. Guidebook 12th Ann. Field Conf., southwest Wind River Basin, 1957, p. $79-88$.

1964, Tertiary geology of the Beaver Rim area, Fremont and Natrona Counties, Wyoming: U.S. Geol. Survey Bull. $1164,99 \mathrm{p}$.

Van Houten, F. B., and Weitz, J. L., 1956, Geologic map of the eastern Beaver Divide-Gas Hills area, Fremont and Natrona Counties, Wyoming: U.S. Geol. Survey Oil and Gas Inv. Map OM-180.

Walker, T. R., 1967, Color of Recent sediments in tropical Mexico-a contribution to the origin of red beds: Geol. Soc. America Bull. v. 78, no. 7, p. 917-920.

Wentworth, C. K., 1922, A scale of grade and class terms of clastic sediments: Jour. Geology, v. 30, no. 5, p. 377-392.

Wilmarth, M. G., 1938, Lexicon of geologic names of the United States: U.S. Geol. Survey Bull. 896, pt. 1, p. 1-1244; pt. 2, p. 1245-2396.

Wood, H. E., 2d, chm., 1941 Nomenclature and correlation of the North American Continental Tertiary: Geol. Soc. America Bull., v. 52, no. 1, p. 1-48.

Wood, H. E., 2d, Seton, Henry, and Hares, C. J., 1936, New data on the Eocene of the Wind River Basin, Wyoming [abs.] : Geol. Soc. America Proc. 1935, p. 394-395.

Wortman, J. L., 1892, Geological and geographical sketch of the Bighorn Basin: Am. Mus. Nat. History Bull., v. 4, p. 135-144.

Zeller, H. D., 1957, The Gas Hills uranium district and some probable controls for ore deposition, in Wyoming Geol. Assoc. Guidebook 12th Ann. Field Conf., southwest Wind River Basin, 1957 : p. 156-160.

- 1958, Gas Hills area, Wyoming: U.S. Geol. Survey TEI-740, p. 106-112. [For sale by Clearinghouse for Federal Sci. and Tech. Inf., Natl. Bur. Standards, U.S. Dept. Commerce, Springfield, Va.]

Zeller, H. D., Soister, P. E., and Hyden, H. J., 1956, Preliminary geologic map of the Gas Hills uranium district, Fremont and Natrona Counties, Wyoming: U.S. Geol. Survey Mineral Inv. Field Studies Map MF-83. 